UNIVERSIDADE DE SÃO PAULO

Faculdade de Filosofia, Letras e Ciências Humanas

Programa de Pós-Graduação em História Econômica

LEONARDO LAGUNA BETFUER

\title{
Pernambuco e a Aliança para o Progresso: ajuda econômica regional no Brasil de João Goulart
}

\author{
Versão Corrigida
}




\section{Pernambuco e a Aliança para o Progresso: ajuda econômica regional no Brasil de João Goulart}

Versão Corrigida

Orientador: PROF. DR. FELIPE PEREIRA LOUREIRO

Dissertação de Mestrado apresentada ao programa de História Econômica da Faculdade de Filosofia Letras e Ciências Humanas (FFLCH-USP) como parte dos requisitos para obtenção do título de mestre. 
Autorizo a reprodução e divulgação total ou parcial deste trabalho, por qualquer meio convencional ou eletrônico, para fins de estudo e pesquisa, desde que citada a fonte. 
Catalogação na Publicação Serviço de Biblioteca e Documentação Faculdade de Filosofia, Letras e Ciências Humanas da Universidade de São Paulo

\section{BB562p}

Betfuer, Leonardo Laguna Pernambuco e a Aliança para o Progresso: ajuda econômica regional no Brasil de João Goulart (19611964) / Leonardo Laguna Betfuer; orientador Felipe Pereira Loureiro. - São Paulo, 2019. 117 f.

Dissertação (Mestrado) - Faculdade de Filosofia, Letras e Ciências Humanas da Universidade de São Paulo. Departamento de História. Área de concentração: História Econômica.

1. Diário de Pernambuco. 2. Aliança para o Progresso. 3. Pernambuco, 4. Relações BrasilEstados Unidos. 


\section{ENTREGA DO EXEMPLAR CORRIGIDO DA DISSERTACÃO/TESE}

\section{Termo de Ciência e Concordância do (a) orientador (a)}

Nome do (a) aluno (a): Leonardo Laguna. Betfuer

Data da defesa: $21 / 208 / 2019$

Nome do Prof. (a) orientador (a): Felipe Pereira Loureiro

Nos termos da legislação vigente, declaro ESTAR CIENTE do conteúdo deste EXEMPLAR CORRIGIDO elaborado em atenção às sugestões dos membros da comissão Julgadora na sessão de defesa do trabalho, manifestando-me plenamente favorável ao seu encaminhamento e publicação no Portal Digital de Teses da USP.

São Paulo, $\underline{30 / 10 / 2019}$

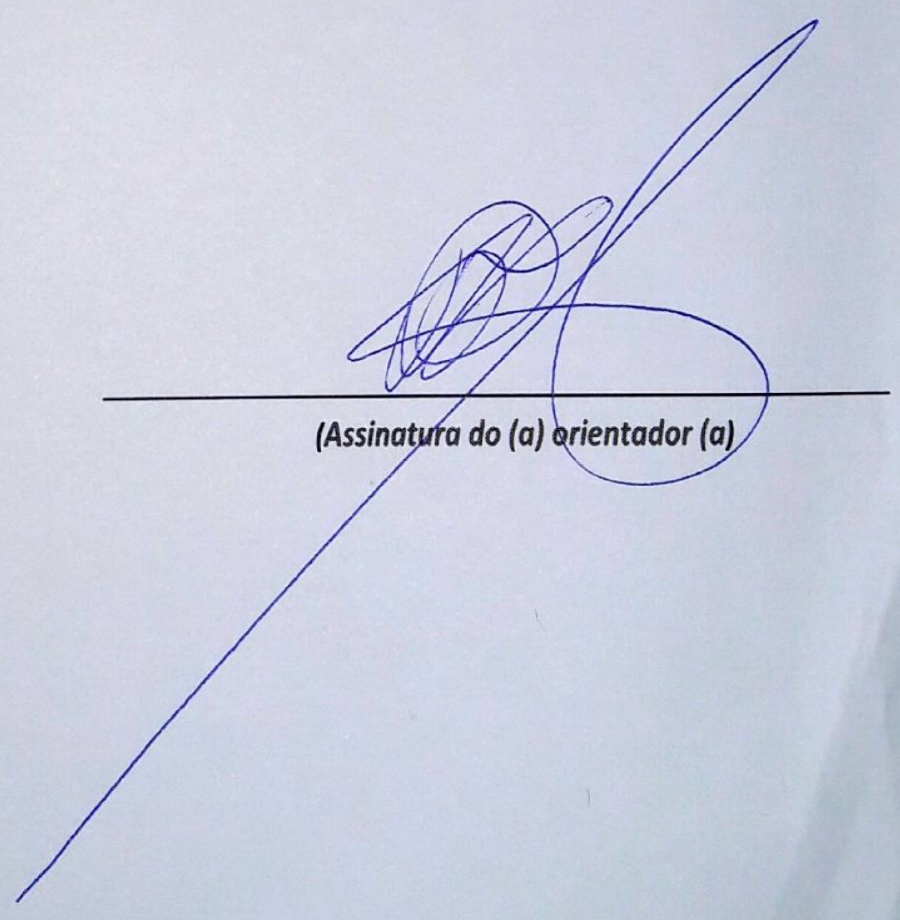


BETFUER, Leonardo L. Pernambuco e a Aliança para o Progresso: ajuda econômica regional no Brasil de João Goulart (1961-1964). Dissertação de Mestrado apresentada à Faculdade de Filosofia Letras e Ciências Humanas da Universidade de São Paulo para a obtenção do título de mestre em História Econômica.

Aprovado em:

Prof. Dr.

Instituição

Julgamento

Assinatura

Prof. Dr.

Instituição

Julgamento

Assinatura

Prof. Dr.

Instituição

Julgamento

Assinatura 


\section{Agradecimentos}

Primeiramente, agradeço à CAPES pela concessão de bolsa ao projeto que resultou nesta dissertação. As opiniões, hipóteses e conclusões ou recomendações expressas neste material são de responsabilidade do autor e não necessariamente refletem a visão da CAPES.

A realização de uma dissertação de mestrado é um processo repleto de dúvidas e incertezas. Assim, a angústia e a ansiedade foram sentimentos que me acompanharam desde o início. Seria impossível concretizar esse sonho sem a ajuda de outras pessoas, as quais dedico esse trabalho. Agradeço à minha família. Aos meus pais, Wagner e Neide, pelo apoio e pela vida. Às minhas irmãs Jéssica, pelo companheirismo e amizade e Ellen, pelo exemplo de luta.

Agradeço imensamente ao meu orientador, Felipe Loureiro, por ter me aberto as portas da universidade pública e por ter acreditado na minha capacidade de realizar esse trabalho. Sem ele, nada disso seria possível e se esse trabalho tem algum mérito é devido às suas correções e contribuições. Muito obrigado por seu tempo e atenção.

Agradeço especialmente ao Michel e Arthur, dois pernambucanos que tornaram possível que eu entendesse um pouco melhor a realidade do meu objeto de estudo. Também os agradeço pelas leituras e contribuições prestadas a esse trabalho. Arthur, obrigado por me receber tão bem no Recife e pela documentação cedida, você foi muito generoso. Michel, eu só posso agradecer pela sua amizade que levarei para sempre no meu coração.

Agradeço aos membros do meu grupo de pesquisa pelo companheirismo, pelas conversas e angústias compartilhadas.

Minha eterna gratidão ao Rafael, que me recebeu no CRUSP em um momento fundamental da minha pesquisa de mestrado.

Agradeço ao Davi, meu amigo e confidente de tantas horas. Obrigado pela paciência e por aguentar meus desabafos e surtos, que não foram poucos. 
"Enquanto metade da humanidade não come. A outra metade não dorme, com medo da que não come". Josué de Castro

"Ô Josué, eu nunca vi tamanha desgraça Quanto mais miséria tem, mais urubu ameaça".

Chico Science 


\section{Resumo}

A Revolução Cubana de janeiro de 1959 promoveu profundas mudanças na política externa dos Estados Unidos para a América Latina. A fim de combater o comunismo, promover a democracia e o desenvolvimento econômico regional, os Estados Unidos lançaram a Aliança para o Progresso, um programa de ajuda econômica que pretendia investir até US\$20 bilhões no continente em uma década. No entanto, ao contrário da proposta original, estudiosos argumentam que a Aliança teria sido utilizada para interferir na política doméstica latino-americana em favor dos interesses estratégicos de Washington. No caso do Brasil, os recursos da Aliança para - Progresso foram utilizados, entre outras coisas, para apoiar políticos que se opunham ao Presidente João Goulart, na tentativa de desestabilizar seu governo. A região Nordeste do Brasil e o estado de Pernambuco, em particular, foram motivo de atenção especial por parte do governo norte-americano devido às forças políticas que disputavam o poder na região, ao grau de subdesenvolvimento socioeconômico regional, e ao nível de agitação social - considerados alarmantes. A presente dissertação de mestrado argumenta que o jornal Diário de Pernambuco utilizou a Aliança para o Progresso para favorecer políticos conservadores do status quo, no caso Cid Sampaio e João Cleofas, ambos da UDN. O jornal também usou a Aliança ativamente para prejudicar candidatos nacionalistas, no caso Miguel Arraes (PST). Argumenta-se também que o jornal usou o programa de ajuda econômica para criticar o Presidente João Goulart, contribuindo para a campanha de desestabilização política que resultou no golpe civil-militar de 1964.

Palavras-chave: Diário de Pernambuco, Aliança para o Progresso, Pernambuco, John Kennedy, Relações Brasil-Estados Unidos. 
Abstract

The Cuban Revolution of January 1959 brought about profound changes in the United States foreign policy towards Latin America. In order to combat communism, promote democracy and regional economic development, the United States launched the Alliance for Progress, an economic aid program that sought to invest up to $\$ 20$ billion on the continent in a decade. However, contrary to the original proposal, scholars argue that the Alliance would have been used to interfere in Latin American domestic politics in favor of Washington's strategic interests. In the case of Brazil, the resources of the Alliance for Progress were used, among other things, to support politicians who opposed President João Goulart in an attempt to destabilize his government. The Northeastern region of Brazil and the State of Pernambuco, in particular, received special attention from the US government due to the political forces that disputed power in the region, the degree of regional socioeconomic underdevelopment, and the level of social unrest, considered alarming. This dissertation argues that the newspaper "Diário de Pernambuco" used the Alliance for Progress to favor conservative politicians of the status quo, in the case Cid Sampaio and João Cleofas, both politicians of UDN. The newspaper also actively used the program to harm nationalist candidates, in the case Miguel Arraes (PST). It is also argued that the newspaper used the Alliance to criticize President João Goulart, contributing to the political destabilization campaign that resulted in the 1964 civilmilitary coup.

Keywords: Pernambuco, Alliance for Progress, economic aid, John Kennedy, BrazilUnited States Relations. 


\section{Lista de Imagens}

Imagem 1: Polígono da Seca - pg. 26.

Imagem 2: Mesorregiões de Pernambuco - pg. 37.

Imagem 3: Capa do Diário de Pernambuco de 02 de outubro de 1962 - pg. 69.

Imagem 4: Charge publicada no Diário de Pernambuco durante a campanha eleitoral de 1962 - pg. 70.

Imagem 5: Propaganda eleitoral do candidato João Cleofas publicada no Diário de Pernambuco - pg. 76.

Imagem 6: Municípios beneficiados pelos convênios de habitação e colonização - pg. 93. 


\section{Lista de Quadros}

Quadro 1: Matérias sobre a Aliança para o Progresso nos estados do Nordeste publicadas no Diário de Pernambuco - pg. 74.

Quadro 2: Distribuição das casas do programa habitacional por municípios do estado de Pernambuco - pg. 97.

Quadro 3 - Doações e empréstimos da Aliança para o Progresso feitos ao estado de Pernambuco na segunda metade de 1962 - pg. 106. 


\section{LISTA DE ABREVIATURAS E SIGLAS}

BID - Banco Interamericano de Desenvolvimento

Bird - Banco Internacional para Reconstrução e Desenvolvimento

BNDE - Banco Nacional de Desenvolvimento Econômico

CEAPA - Comissão Especial dos Acordos sobre Produtos Agrícolas

CEPAL - Comissão Latino-americana para o Desenvolvimento

CIA - Central Intelligence Agency

CIES - Conselho Interamericano Econômico e Social

COPERBO - Companhia Pernambucana de Borracha Sintética

CRC - Companhia de Revenda e Colonização

DNOCS - Departamento Nacional de Obras Contra Secas

EUA - Estados Unidos da América

EXIMBANK - Banco de Importações e Exportações

FBI - Federal Bureau of Investigation

FMI - Fundo Monetário Internacional

FOIA - Freedom of Information Act

FSESP - Fundação Serviço Especial de Saúde Pública

IBAD - Instituto Brasileiro de Ação Democrática

IPES - Instituto de Pesquisa e Estudos Sociais

NSC - National Security Concil (Conselho Nacional de Segurança)

OEA - Organização dos Estados Americanos

PCB - Partido Comunista Brasileiro

PTB - Partido Trabalhista Brasileiro

SAPPP - Sociedade Agrícola e Pecuária dos Plantadores de Pernambuco

SORPE - Serviço de Orientação Rural de Pernambuco 
SSCM - Serviço Social Contra o Mocambo

SUDENE - Superintendência do Desenvolvimento do Nordeste

UDN - União Democrática Nacional

URSS - União das Repúblicas Socialistas Soviética

USAID - United States Agency for International Development

USIA - United States Information Agency 


\section{Sumário}

Introdução

Capítulo 01: Contextualização socioeconômica e política do Nordeste e de Pernambuco......... 26

1.1 - Nordeste e os esforços Federais para promover o desenvolvimento regional...............26

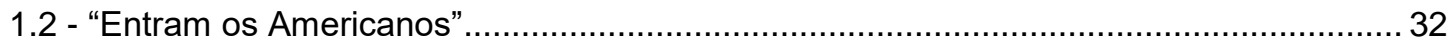

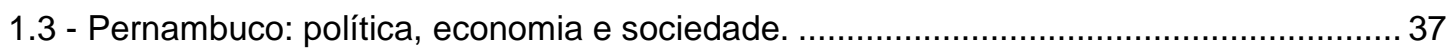

1.4 - Agamenon Magalhães, a Oligarquia Pessedista e os demais partidos em Pernambuco.45

1.5 - Cid Sampaio e Miguel Arraes: dois lados de uma mesma moeda. ...............................50

Capítulo 02: A Aliança para o Progresso narrada através do Diário de Pernambuco.................55

2.1 - O Progresso da Aliança narrado através das publicações do Diário de Pernambuco... 55

Capítulo 03: A implementação dos acordos da Aliança para o Progresso no estado de Pernambuco durante seus anos iniciais.

3.1 - A Aliança para o Progresso como agente de modernização............................................. 86

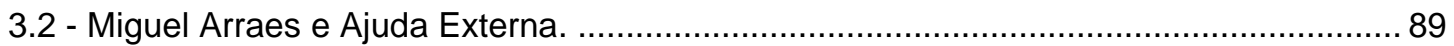

3.3 - Os convênios e sua implementação .............................................................................. 93

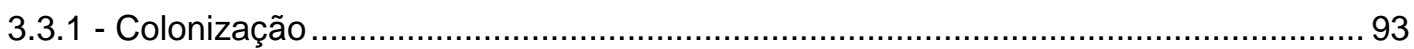

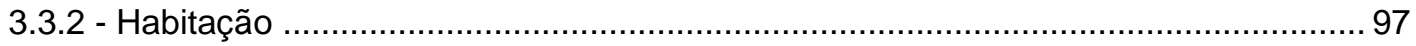

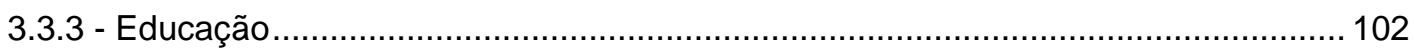

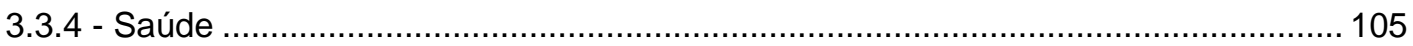

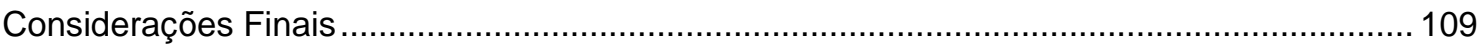

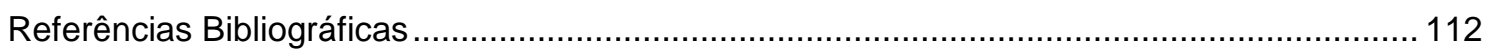




\section{Introdução}

Os anos que se seguiram à Revolução Cubana (1959) foram os mais significativos para as relações entre os Estados Unidos e a América Latina no contexto da Guerra Fria. No imediato pós-2 $2^{\underline{a}}$ guerra, o governo norte-americano interpretou que a América Latina estaria segura da influência comunista. Em comparação à Europa e à Ásia, a região parecia ser um problema menor. Em 1958, o fracasso de uma excursão do vice-presidente Richard Nixon por alguns países da América Latina modificou essa percepção. A visita de Nixon foi marcada por manifestações de antiamericanismo, com destaque para os acontecimentos no Peru e na Venezuela, onde essas manifestações assumiram caráter de motim. Nixon, atacado pelo povo, teve de deixar a Venezuela sob a proteção de tanques (BANDEIRA, 1973, 378; LEACOCK, 1990, 6-12).

Esses acontecimentos assombraram os norte-americanos, que "subitamente redescobriram a América Latina". O Presidente do Brasil, Juscelino Kubitschek (19561961), na esteira desse processo, escreveu ao Presidente Dwight D. Eisenhower (1953-1961), "exortando-o a rever a política dos Estados Unidos para a América Latina" (BANDEIRA, 1973, 382). Kubitscheck propôs a Operação Pan-americana (OPA), "fundamentada na tese de que os Estados Unidos deviam considerar prioritariamente a luta contra o subdesenvolvimento" na América Latina em detrimento de políticas de repressão (BANDEIRA, 1973, 389).

A Operação Pan-Americana buscava comprometer Washington num programa multilateral de desenvolvimento econômico de longo alcance e obter maiores créditos para a América Latina. "A OPA pretendia incrementar os investimentos nas regiões economicamente atrasadas do continente, compensando a escassez de capitais internos", promover a assistência técnica e proteger os preços dos produtos primários exportados (VIZENTINI, 2003, 22). O governo norte-americano, no entanto, almejava apenas discutir projetos específicos, "como a criação do Banco Interamericano de Desenvolvimento (BID), a cooperação técnica e a forma de ampliar a corrente de investimentos privados para as zonas menos desenvolvidas" (BANDEIRA, 1973, 389).

Foi o sucesso de Fidel Castro e a adoção do comunismo em Cuba, ou seja, dentro do território que os Estados Unidos consideravam sua fronteira natural, que afetou profundamente a política externa norte-americana para o continente. Isso porque a ilha não era o único lugar na região onde camponeses pobres eram 
explorados e reprimidos por seus governos. Sob esse aspecto, na visão do recémempossado governo John F. Kennedy (1961-1963), todo o hemisfério poderia explodir em revoluções do tipo comunista. Nesse sentido, enquanto o governo Eisenhower preocupou-se em criar um clima favorável para os investimentos de empresários americanos na América Latina, incentivando a estabilidade monetária e protegendo os investimentos estrangeiros, o governo Kennedy tentou se afastar desse posicionamento que na prática havia fomentado o antiamericanismo na região. (LEACOCK, 1990, 6-12; TAFFET, 2007, 7).

Dentro desse contexto, em março de 1961, o Presidente Kennedy lançou o maior programa de ajuda econômica para a América Latina da história. Batizado de Aliança para o Progresso, tal programa previa investimentos que chegariam a US\$20 bilhões em uma década. A Aliança pretendia promover crescimento econômico e reforma política na América Latina. Oferecia apoio a regimes que respeitassem instituições democráticas, promovessem políticas de incremento do padrão de vida da população e apoiassem reformas sociais, como reformas tributária e agrária. Reforma democrática e desenvolvimento econômico com equidade social, portanto, eram os principais pontos da estratégia da Aliança para o Progresso contra a subversão comunista (TAFFET, 2007, 5; LOUREIRO, 2014, 323-327).

O Brasil era visto como um país chave para o sucesso da Aliança na América Latina. Primeiro, pela posição geográfica estratégica, em virtude de sua proporção continental. Segundo, pela sua população, em torno de 70 milhões em 1960. Perder Cuba com uma população de 6 milhões já era ruim o bastante; a possibilidade de perder o Brasil para o campo comunista era considerado um desastre para os Estados Unidos (LEACOCK, 1990, 13-33). Além disso, o Brasil era tradicionalmente visto como um aliado na região, devido às tradicionais relações "especiais" que os dois países tinham. Esta relação fortaleceu-se no começo do século XX por aquilo que estudiosos denominaram como uma "Aliança não escrita", tendo seu ápice na participação do Brasil na Segunda Guerra Mundial ao lado dos Aliados (BURNS, 1966). ${ }^{1}$

A região Nordeste do Brasil, em especial, era motivo de grande preocupação para o governo norte-americano. O Nordeste era uma região extremamente

\footnotetext{
${ }^{1}$ Durante a Primeira República, as relações EUA-Brasil seguiram o modelo de uma aliança informal, ou como caracterizada por Bradford Burns, de uma "aliança não escrita". Sobre a "Aliança não escrita" ver: Bradford Burns, The Unwritten Alliance, Rio Branco and Brazilian-American Relations (London, New York: Columbia University Press, 1966).
} 
subdesenvolvida no início dos anos 1960 - muito mais do que atualmente. Indicadores socioeconômicos regionais eram compatíveis com os de alguns dos países mais pobres da África e da Ásia. Relatos de jornalistas e políticos estadunidenses que visitaram o Nordeste, sobretudo as reportagens do jornalista do New York Times Tad Szulc em 1960, mexeram com a opinião pública nos Estados Unidos e levavam Washington a crer que a região estaria à beira de uma violenta insurreição. Nesse sentido, entende-se o porquê de o Presidente Kennedy ter feito do Nordeste o alvo de máxima prioridade para a Aliança (PAGE, 1972, 11-29; RABE, 1999, 170-71).

Apesar das expectativas e do notório interesse dos Estados Unidos com relação ao sucesso da Aliança no Brasil, e principalmente na região Nordeste, estudiosos enfatizam que os fundos da Aliança teriam sido usados como uma ferramenta para desestabilizar o governo do Presidente João Goulart, particularmente quando se tratava de transferir recursos para governadores estaduais que se opunham ao presidente por meio de uma política conhecida como llhas de Sanidade (LOUREIRO, 2017; TAFFET, 2006, 109-115; LEACOCK, 1990, 160-4). Essa campanha política contribuiu para o golpe que inaugurou a ditadura militar no Brasil em março de 1964.

Os estudiosos que se debruçaram sobre o tema concordam que as ilhas de sanidade teriam sido um meio de o governo norte-americano interferir na política doméstica brasileira e desestabilizar o governo Goulart. ${ }^{2}$ Nesse sentido, a origem da assistência bilateral direta no Brasil e na região Nordeste estava no estado de Pernambuco, que era considerado absolutamente crucial por Washington, em razão de sua importância econômica, populacional e estratégica, para os demais desenvolvimentos que se dessem na região. A embaixada norte-americana, já em 1961, tinha demonstrado preocupação com o resultado das eleições estaduais que ocorreriam em outubro de 1962. No caso de Pernambuco, essas eleições prometiam ser um embate entre grupos de esquerda, metaforizados pelo então prefeito de Recife, Miguel Arraes, e representantes do poder político tradicional, personalizado no candidato apoiado pela União Democrática Nacional (UDN), João Cleofas (ROETT, 1972, 130-31).

Dentro de uma das inúmeras perspectivas da chamada História Global, "durante as últimas décadas, estudiosos vêm investigando como o Terceiro Mundo

\footnotetext{
2 Dentre esses estudiosos destacam-se Jeffrey Taffet e Felipe Loureiro. A posição da literatura em
} relação ao tema será discutida mais adiante nessa introdução. 
vivenciou sua própria Guerra-Fria", combatida ideologicamente por atores estatais e não-estatais e não apenas por Washington e Moscou (LOUREIRO, GOMES e BRAGA, 2018, 02). Desse modo, faz-se necessário novos estudos sobre a Guerra Fria a partir da periferia do conflito, ou seja, a partir do então chamado Terceiro Mundo.

Nesse sentido, acredita-se, que as peculiaridades políticas e sociais que envolvem o estado de Pernambuco, no início dos anos 1960, oferecem uma perspectiva privilegiada do modo como atores locais vivenciaram e até mesmo combateram ideologicamente durante a Guerra Fria. Pernambuco apresentou-se aos olhares de formuladores políticos em Washington como uma das principais questões de segurança no hemisfério e esta perspectiva interferiu ativamente no modo como a Guerra Fria foi experimentada no estado, constituindo assim um excelente estudo de caso para esse tipo de análise, referente as percepções de agentes do Terceiro Mundo e de sua vivência a respeito da Guerra Fria.

Acreditamos que essa seja uma das principais contribuições dessa dissertação de mestrado para nosso campo de pesquisa, pois, a partir da análise do conteúdo publicado pelo jornal Diário de Pernambuco (fonte primária essencial deste trabalho), foi possível verificar como a Guerra Fria foi percebida e vivenciada pelos grupos conservadores do status quo no estado, representados pelo jornal, e como estes grupos se valeram da disputa ideológica para interferir na política regional. A Aliança para o Progresso se converteu em instrumento político de luta ideológica para esses grupos conservadores, como será demonstrado, particularmente, no capítulo 2. Além disso, durante muito tempo a Aliança para o Progresso foi interpretada como uma iniciativa quase que exclusivamente norte-americana. $O$ uso político da Aliança para o Progresso pelos Estados Unidos também foi bastante destacado pelos trabalhos anteriores a este (LOUREIRO, 2014, 2017, 2019; TAFFET, 2006; LEACOCK, 1990; BARROS, 2017). Essa dissertação coloca os agentes brasileiros no centro do processo e analisa como estes se valeram da Aliança como instrumento político.

Com relação a utilização da Aliança para o Progresso como instrumento político de interferência na política interna brasileira, podemos destacar duas linhas de interpretação. A primeira delas enfatiza o papel das empresas privadas norteamericanas numa mudança de direcionamento nos propósitos da Aliança. É o caso de Ruth Leacock (1990, 9), para quem o projeto da Aliança teria sido modificado em resposta às pressões do Congresso e dos grupos de empresários norte-americanos. Especialmente no caso brasileiro, as empresas americanas teriam desempenhado 
papel importante na alteração de diretrizes de políticas e na oposição dos Estados Unidos à Brasília. As políticas estatais e nacionalistas perseguidas pelo Brasil - como a expropriação de empresas norte-americanas e a possibilidade de aprovação de uma lei restritiva à remessa de lucros por empresas estrangeiras - desgastaram as relações entre o governo norte-americano e o Presidente Goulart. O programa da Aliança para o Progresso, então, teria passado a ser utilizado, na visão da autora, para desestabilizar o governo Jango, através do financiamento direto de governadores antiGoulart. O golpe de março de 1964 garantiu o Brasil como uma zona para investimentos corporativos norte-americanos e o isolou da influência de Fidel Castro. Moniz Bandeira (1977) segue uma linha próxima de Leacock. Ele destaca que o traço marcante na deterioração das relações entre os governos do Brasil e Estados Unidos aconteceram principalmente devido às frustrações nas negociações das subsidiárias norte-americanas, International Telephone and Telegraph (ITT) e American \& Foreign Power (AMFORP), desapropriadas pelo governo brasileiro e também pela incapacidade do governo Goulart de levar adiante o programa passo-a-passo de estabilização econômica estabelecido por Washington (LOUREIRO, 2014, 338-9). ${ }^{3}$

A segunda linha de interpretação enfatiza as preocupações com as questões de segurança por parte do governo norte-americano. Michael Weis $(2001,341)$ destaca que o governo Kennedy viu suas intenções frustradas pelas posições nacionalistas da Política Externa Independente (PEI) do governo brasileiro. ${ }^{4}$ Este, por sua vez, via na obsessão dos EUA com a Guerra Fria e com o liberalismo econômico um obstáculo ao desenvolvimento econômico do Brasil. Para o autor, a PEI comprometeu as chances da administração Kennedy de usar a Aliança como arma na Guerra Fria no hemisfério; além disso, ao frustrar a administração Kennedy, levou-a a se afastar dos políticos reformadores da América Latina e a se aproximarem dos militares para ajudar no isolamento de Fidel Castro.

Para Jeffrey Taffet $(2007,5)$, em vez de comprometer os recursos da Aliança com projetos humanitários, os Estados Unidos canalizaram seu dinheiro para projetos

\footnotetext{
${ }^{3}$ Sobre o Programa de Estabilização Passo-a-passo imposto pelos Estados Unidos ao Brasil ver: Felipe Loureiro, "The Alliance For or Against Progress? US-Brazilian Financial Relations in the Early 1960s." Journal of Latin American Studies 46 (02), (2014), p. 323- 51.

${ }^{4}$ A PEI estabelecia princípios como o incremento das exportações brasileiras para todos os países, inclusive os socialistas, a autodeterminação dos povos e a não intervenção nos assuntos de outros países, aplicados inclusive em relação a Cuba. Sobre a PEI ver: Keith Larry Storss, Brazil's Independent Foreign Policy, 1961-1964: Background, Tenets, Linkage to Domestic Politics, and Aftermath (Thesis Presented to the Faculty of the Graduate School of Cornell University, 1973).
} 
explicitamente políticos. Isso ocorreu, no caso do Brasil, através da política das llhas de Sanidade, que teriam surgido a partir de meados de 1963, à medida que o governo norte-americano se comprometeu com uma posição cada vez mais anti-Goulart. Conforme Taffet, o embaixador Lincoln Gordon assumiu a liderança no desenvolvimento dessa abordagem hostil, justificando sua oposição ao governo federal brasileiro ao sugerir, baseado em poucos indícios, que Goulart desejava criar uma ditadura no Brasil. Para Gordon, a solução teria sido promover e fortalecer os governadores anti-comunistas que poderiam desafiar o governo nacional.

Stephen G. Rabe, (1999), ao analisar a política externa norte-americana para a América Latina, mostra que o governo dos Estados Unidos nunca deixou de interferir nos assuntos internos dos países latino-americanos, sendo os recursos da Aliança para o Progresso utilizados para esse fim. O autor afirma que em 1962 o governo americano alocou US\$33 milhões em programas sociais no Nordeste, com a marca da Aliança para o Progresso, com o intuito de interferir no resultado das eleições de outubro para o Congresso Nacional. Washington passou por cima da Superintendência para o Desenvolvimento do Nordeste (SUDENE) e trabalhou com governadores de estados considerados anti-Goulart e anticomunistas. Fica evidente que Washington trabalhou diretamente no Nordeste para desestabilizar o governo Goulart, mas não se sabe como os agentes públicos brasileiros reagiram e se valeram desta política norte-americana.

Felipe Loureiro $(2017,12 ; 2019)$ afirma que as Ilhas de Sanidade tiveram três objetivos principais. Primeiro, constranger politicamente o governo Goulart. Segundo, fomentar candidaturas presidenciais favoráveis aos Estados Unidos nas eleições previstas para 1965. Terceiro, a partir de meados de 1963, usar os estados governados por políticos amigáveis como arma de defesa contra movimentos ilegais de Goulart e ao mesmo tempo como meio de desestabilizar seu governo. ${ }^{5}$

Até hoje, porém, representantes do governo norte-americano não reconhecem que recursos da Aliança para o Progresso teriam sido utilizados para interferir na política doméstica brasileira. O embaixador norte-americano, Lincoln Gordon (2001, 102-111), por exemplo, afirmou que as Ilhas de Sanidade foram uma forma de evitar ao máximo a interrupção da ajuda econômica da Aliança para o Progresso ao Brasil.

\footnotetext{
${ }^{5}$ O trabalho de 2019 a que nos referimos é: Felipe Loureiro, "Making the Alliance for Progress for A Few: U.S. Economic Aid to Brazilian States in Cold War Brazil (1961-1964)," Journal of Cold War Studies, (2019), (na prensa).
} 
Segundo Gordon, as Ilhas de Sanidade eram constituídas pelos estados mais bem administrados e tecnicamente melhor preparados para receber recursos, sem que, supostamente, critérios políticos tivessem sido envolvidos na alocação da ajuda econômica da Aliança. "Contrariamente a muitas das alegações que já foram publicadas, o governo americano não procurou debilitar o governo Goulart colocandoo sob pressão econômica". Em vez de aplicar pressões econômicas destinadas a enfraquecer o governo Goulart, a política teria sido "manter a assistência econômica onde ela poderia ser eficaz" (GORDON, 2001,105-106).

Como já citado, a origem da assistência bilateral direta no Brasil e na região Nordeste estava no estado de Pernambuco, que era considerado absolutamente crucial por Washington. $O$ estado foi o primeiro a assinar um acordo com o governo dos Estados Unidos no âmbito da Aliança para o Progresso em junho de 1962.

Dois trabalhos se destacam ao analisar a Aliança para o Progresso em Pernambuco, "The Politics of Foreign Aid" de Riordan Roett e "The Revolution that Never Was" de Joseph Page. Para Roett (1972, 10), o conservadorismo foi a marca do programa de ajuda externa no Nordeste brasileiro. Os Estados Unidos permitiram que a Aliança para o Progresso fosse utilizada para manter e fortalecer a ordem tradicional dominante. Incapazes de ajudar a suprir a necessidade básica de mudança e modernização, os Estados Unidos escolheram uma política no Nordeste de cooperação com as elites regionais e justificaram a política em termos de uma ameaça comunista. Essa perspectiva confere o protagonismo da escolha na aplicação dos recursos da Aliança aos Estados Unidos, sem considerar o papel dos agentes locais conservadores nesse processo.

Joseph Page $(1972,11)$ afirma que a Aliança se encontrou dividida entre seus objetivos publicamente declarados, humanitários e reformistas, e as considerações sobre a segurança dos Estados Unidos, tendo esta última prevalecido. A Aliança para o Progresso buscou primeiro preservar o status quo e manter a ordem estabelecida. Os recursos da Aliança para o Progresso foram, em Pernambuco, utilizados para conter o crescimento político do governador Miguel Arraes e, do ponto de vista político, a Aliança obteve seus objetivos de manter o status quo na região Nordeste, que não se tornou "outra Cuba". É certo que essa abordagem confere grande peso aos movimentos de esquerda ao sugerir que uma revolução poderia ocorrer, como sugere o título "A Revolução que não houve". 
O objetivo central desta dissertação de mestrado é compreender o uso político da Aliança para o Progresso, pelo jornal Diário de Pernambuco, a partir da narrativa publicada pelo jornal. Partindo-se da pergunta: como o Diário de Pernambuco utilizou politicamente a Aliança pata o Progresso no sentido de atender aos interesses dos grupos conservadores locais, representados pelo jornal? Busca-se entender as relações entre o conteúdo publicado e os principais acontecimentos políticos do estado de Pernambuco e do governo federal. Nesse sentido, compreende-se o jornal fundamentalmente como um instrumento de intervenção na vida social a serviço dos grupos sociais conservadores do status quo.

Para além das questões relativas ao fracasso da Aliança, já amplamente discutidas pela historiografia, a utilização política da Aliança por grupos políticos e econômicos brasileiros foi muito pouco estudada. Sob esse aspecto, o jornal Diário de Pernambuco, além de fonte primária, pode ser também objeto de pesquisa, na medida que representa em suas páginas os interesses de grupos políticos e econômicos ligados aos setores sociais conservadores do status quo em Pernambuco. Tomado como objeto de estudo, o jornal é interpretado, pelo historiador, fundamentalmente como "um instrumento de manipulação de interesses e intervenção na vida social". O Diário de Pernambuco apresentava a visão de mundo dos industriais e latifundiários, os quais eram mais próximos dos funcionários do consulado norte-americano (CAPELATO, 1988; PORFÍRIO, 2008). ${ }^{6}$ Assim, deve-se historicizar o jornal e analisar o perfil de seus principais colaboradores, buscando traçar um perfil ideológico da publicação. É importante analisar os editoriais na busca da opinião do jornal, mas não só isso. O espaço, o destaque e o tratamento dado as notícias também é repleto de significado e, portanto, é fundamental para a análise do jornal pelo historiador. Além da metodologia de análise de jornais proposta por Capelato, onde o jornal é interpretado como um instrumento de intervenção na realidade social, esse trabalho vale-se de metodologias clássicas de história para reconstrução do processo histórico, através do cruzamento de fontes de natureza variada.

A análise da conjuntura dos eventos relacionados à Aliança para o Progresso tal como representados pelo jornal pode lançar luz em questões ligadas ao seu uso político por grupos políticos e econômicos nacionais e como esses grupos vivenciaram

\footnotetext{
${ }^{6}$ Sobre o uso de jornais como fontes históricas ver: Maria Helena Capelato, Imprensa e História do Brasil (São Paulo: Alfa e Ômega, 1988) e Tânia Regina de Lucca, História dos, nos e por meio dos periódicos. (In: PINSKY, C. B. (org.). Fontes Históricas. São Paulo: Contexto, 2005).
} 
a Guerra Fria no estado de Pernambuco. De um modo geral, a historiografia sobre a Aliança para o Progresso analisou o uso político da Aliança, pelos Estados Unidos, como instrumento de intervenção na América Latina. O que esse trabalho faz é analisar como grupos nacionais reagiram a essa política intervencionista na busca de seus objetivos e interesses políticos. Ainda que as relações Estados Unidos e estados brasileiros sejam assimétricas, acredita-se que os estados (representados por grupos sociais) não agiram passivamente, mas buscaram conduzir a Aliança no sentido dos seus interesses.

A principal fonte histórica para esse trabalho foi o próprio jornal Diário de Pernambuco. O jornal foi líder de vendas no Norte e Nordeste nos 1960. A consulta ao Diário de Pernambuco foi feita por meio da Hemeroteca Digital da Biblioteca Nacional. Através de seu mecanismo de busca por palavras chave foram encontradas e analisadas 515 matérias a respeito da Aliança para o Progresso no período entre janeiro de 1960 e maio de 1964. Assim, constituímos uma longa série de pesquisa entre artigos, editoriais e notícias.

O Jornal do Commercio também foi consultado para efeito de comparação e como complemento para análise do conteúdo do Diário de Pernambuco. O material referente ao Jornal do Commercio foi gentilmente cedido pelo pesquisador Arthur Victor Gomes Barros e colhido junto ao Arquivo Público Estadual Jordão Emerenciano durante sua pesquisa de mestrado no ano de 2016.

Além dos jornais, utilizamos documentos de órgãos oficiais, de natureza tanto pública quanto confidencial. Em relação aos documentos oficiais públicos brasileiros, estes foram obtidos junto ao Arquivo Público Estadual Jordão Emerenciano, em Recife, durante nossa pesquisa de campo no ano de 2017.

Sobre as fontes oficiais estrangeiras, utilizamos, sobretudo, documentos diplomáticos dos Estados Unidos, disponíveis online no endereço eletrônico do Departamento de Estado dos Estados Unidos (Foreign Relations of the United States, FRUS), e nos sítios da Biblioteca John Kennedy e do Arquivo Público NorteAmericano (National Archives and Records Administration, NARA). Lançamos mão também dos documentos digitalizados pelo projeto Opening the Archives, realizado em parceria entre a Universidade de Brown (EUA) e a Universidade Estadual de Maringá (PR), coordenado pelo prof. James Green e Sidney Munhoz (UEM) respectivamente. Parte da documentação oficial do governo norte-americano foi 
gentilmente cedida pelo nosso orientador, Felipe Loureiro, e obtida durante pesquisa de campo no ano de 2014.

Adotamos a administração John Kennedy nos Estados Unidos (janeiro de 1961 - novembro de 1963) como início do nosso recorte temporal, exatamente por ter sido o governo idealizador da Aliança para o Progresso, e como marco final o golpe militar brasileiro de 1964, que mudou totalmente as relações entre os Estados Unidos e Brasil, e os governos locais.

Essa dissertação apresenta três capítulos. O capítulo 1 traça um retrato do Nordeste e de Pernambuco no final dos anos 1950 e início dos anos 1960. Esse capítulo historiza as ações do Estado na busca do desenvolvimento da região e os primeiros contatos do governo norte-americano com o Nordeste nesse mesmo sentido. Além disso, o capítulo reconstitui a formação dos partidos e a emergência dos principais atores políticos estaduais.

O capítulo 2 busca compreender como o jornal Diário de Pernambuco retratou a Aliança para o Progresso em suas páginas. Enquanto a maioria dos trabalhos sobre a Aliança tratam da interferência na política latino-americana, por parte dos Estados Unidos, por meio do programa Aliança para o Progresso, esse capítulo mostra o seu uso político realizado por agentes locais, no caso pelos grupos representados pelo Diário de Pernambuco. Esse capítulo reconta a história da Aliança no estado de Pernambuco e no Brasil, a partir do conteúdo publicado pelo jornal, considerando aspectos da política nacional e regional. A principal contribuição desse capítulo está em mostrar que os grupos sociais latino americanos não foram meros agentes passivos na implementação do programa. Ao contrário, agiram ativamente buscando interferir na política local e nacional, usando como ferramenta a Aliança para o Progresso.

O capítulo 3, por fim, funciona como uma espécie de prestação de contas sobre como projetos da Aliança para o Progresso foram implementados no estado de Pernambuco. Esse capítulo busca reconstituir o processo de implementação dos convênios assinados com o estado nos seus anos iniciais e seu legado, levando em consideração dois condicionantes fundamentais: a Aliança como agente de modernização e as relações entre o governador Miguel Arraes e a ajuda externa. 


\section{Capítulo 01: Contextualização socioeconômica e política do Nordeste e de Pernambuco.}

Este capítulo tem por objetivos construir um panorama do Nordeste brasileiro e das tentativas de promover o desenvolvimento da região, por parte do Governo Federal e a partir da Aliança para o Progresso dos Estados Unidos; levantar os aspectos socioeconômicos do estado de Pernambuco que, segundo estudiosos do tema, teriam despertado a atenção do governo norte-americano em relação a Pernambuco; e apresentar as particularidades dos partidos e dos principais atores políticos do estado no final dos anos 1950 e início dos anos 1960. Desse modo, pretende-se oferecer uma visão complexa das forças sociais e políticas que disputavam o poder em Pernambuco nos primeiros anos da década de 1960.

\section{1 - Nordeste e os esforços Federais para promover o desenvolvimento regional. $^{7}$}

A região Nordeste é formada por nove estados, totalizando cerca de 1.558.000 $\mathrm{km}^{2}$. Isso equivale a cerca de um sexto da área total do Brasil. Originalmente, apenas Alagoas, Pernambuco, Paraíba, Rio Grande do Norte e Ceará formavam o Nordeste. Na primeira metade do século XX, os estados do Maranhão, Piauí, Bahia e Sergipe passaram a compor o conjunto de estados da região. A integração desses novos estados deve-se, em parte, à criação do "Polígono da Seca", em 1936, pelo governo federal para fins de assistência financeira. Polígono da Seca é uma área, definida por lei, do semiárido nordestino e que enfrenta problemas de estiagem. Com a exceção do Maranhão, a maior parte da região Nordeste fica nessa área. O Polígono representa $56 \%$ da área terrestre do Nordeste. Piauí e Bahia são responsáveis por $60 \%$ da área de todo o Polígono. Um pequeno setor de Minas Gerais também se tornou parte do Polígono para fins de assistência federal (ROETT, 1971, $11){ }^{8}$

\footnotetext{
${ }^{7}$ Esta seção baseia-se, principalmente, na obra The Politics of Foreign Aid, 1972, de Riordan Roett. ${ }^{8}$ A legislação que definiu o Polígono da Seca foi elaborada em 1946, mas, só entrou em vigor a partir do Decreto-Lei oㅡ 63.778 de 11 de dezembro de 1968 (BARROS, 2017, 57).
} 
Imagem 1: Polígono da Seca

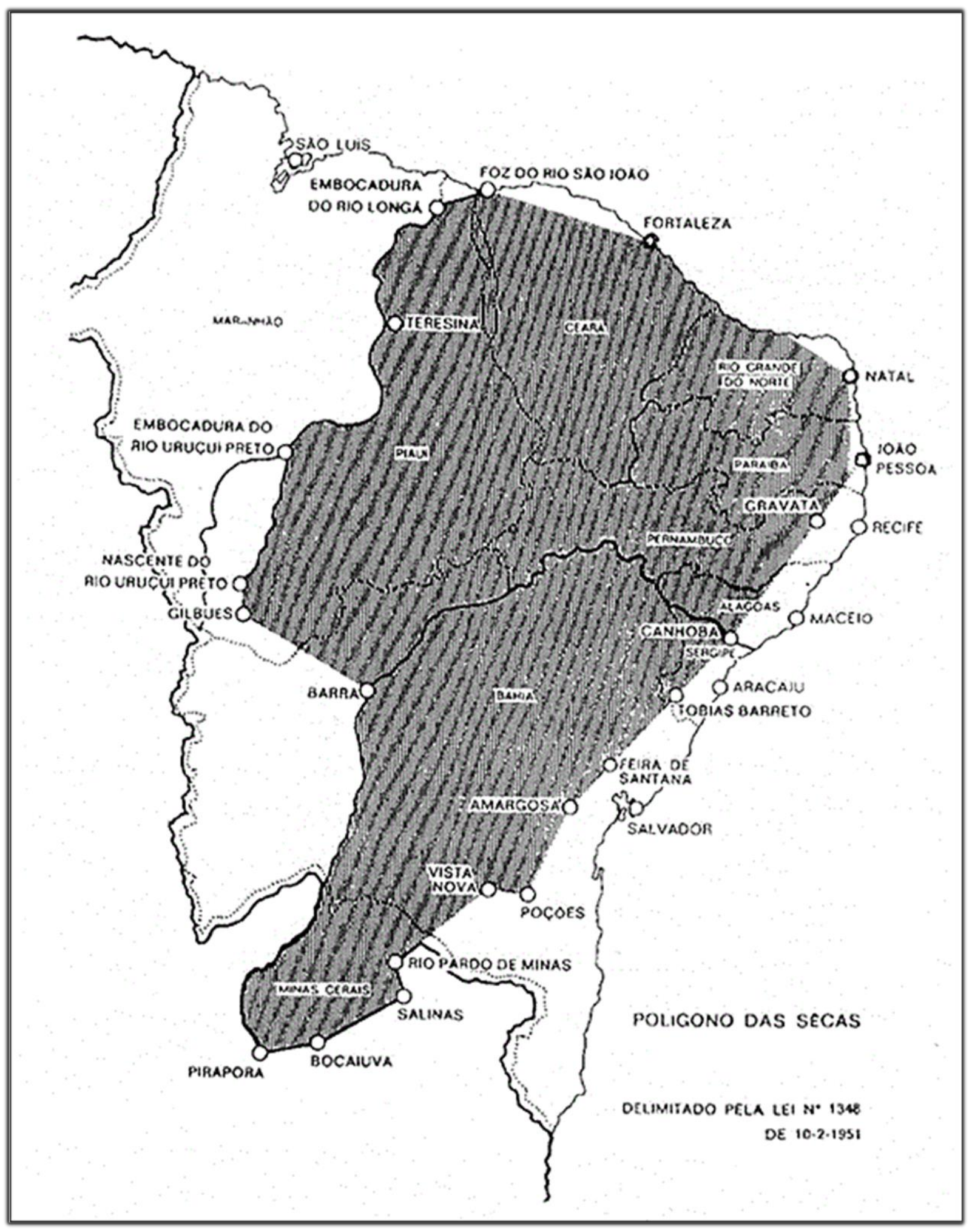

Fonte: Aldo da C. Rebouças, "Água na região Nordeste: desperdício e escassez", Estudos Avançados São Paulo, v. 11, n. 29, (1997), p. 127-154. Disponível em: http://www.scielo.br/scielo.php?script=sci arttext\&pid=S0103-40141997000100007\&lng=en\&nrm=iso Acesso em: 22/04/2019. 
No início dos anos 1960, o Nordeste tinha aproximadamente 24 milhões de habitantes, cerca de um terço da população total do Brasil, estimada em 77 milhões de pessoas no período. A taxa de mortalidade da região era estimada em $60 \%$ durante o primeiro ano de vida. A expectativa de vida era de apenas 35 anos para $80 \%$ da população. O Nordeste tinha ainda elevada taxa de analfabetismo e subnutrição. Estes índices o equiparavam a alguns países da África e Ásia, e colocavam o Nordeste entre as regiões mais pobres do mundo (PAGE, 1972, 30-32, ROETT,1971, 16).

O Nordeste é definido por duas grandes sub-regiões: a faixa húmida da Zona da Mata, que abrange a costa leste nordestina e o Maranhão, e o semiárido, com uma área de transição chamada de agreste. Estas sub-regiões são caracterizadas por solos, condições climáticas, densidade populacional, organização econômica e estrutura social diferentes. A cultura da cana-de-açúcar floresceu na Zona da Mata, uma área de solo de massapê que recebe chuvas abundantes. O Agreste é a área de transição. Historicamente, a região é constituída por fazendas de subsistência que produzem bens para o mercado local. O Sertão é o interior semiárido do Nordeste. É uma área de grandes fazendas de gado e agricultura de subsistência, além de algumas culturas comerciais, com destaque para o algodão. No Sertão, surtos agudos de fome surgem com as secas, que se intercalam com períodos de relativa abundância de alimentos. (ROETT, 1971,12; CASTRO, 1984, 175). ${ }^{9}$

A ocupação e a efetivação da colonização portuguesa na região deveram-se à economia açucareira, que se desenvolveu nos séculos XVI e XVII. A região se tornou uma das maiores produtoras de açúcar do mundo. A produção da cana-de-açúcar se estabeleceu na faixa húmida da Zona da Mata por meio de um sistema de agricultura baseado em grandes propriedades de terras, mão de obra escrava e monocultura. 0 sistema de plantation estabelecido na região foi agente imediato de profunda transformação social e cultural, onde africanos escravizados e seus descendentes proviam mão de obra (CASTRO, 1984, 114).

A produção de açúcar no Nordeste começou a declinar, relativamente falando, no século XVII devido à concorrência com o açúcar caribenho. $A$ transferência do centro econômico nacional para a região centro-sul do Brasil, nos séculos XVIII e XIX, intensificou esse declínio. A região, então, perdeu o foco de atenção do governo central. Isso permitiu, segundo Josué de Castro (1984), a manutenção do controle

\footnotetext{
${ }^{9}$ As principais secas que afligiram o Nordeste, do início do século XX até a final da década de 1960 , ocorreram em: 1930, 1932, 1954, 1958, 1962, 1963 e 1966.
} 
político regional pelos latifundiários da elite local. As secas que assolam o Nordeste resultavam em mortes e êxodo rural, sendo motivo de preocupação desde o século XIX (PAGE, 1972, 30-46; CASTRO, 1984, 116).

Nesse sentido, ainda no século XIX, foram criados programas de combate à seca. Em 1889, foi realizado o primeiro programa de construção de barragens. Em 1909, a Inspetoria de Obras Contra as Secas, que daria origem ao Departamento Nacional de Obras Contra as Secas (DNOCS), foi criada (ROETT, 1971, 22).

No início do século XX, a bancada do Nordeste no Congresso Nacional começou a ganhar apoio para aprovar legislação de combate à seca. A Constituição de 1934 previa que 4\% de todas as receitas do imposto de renda federal deveria ser usada no Nordeste. A Constituição de 1946 estabeleceu que 3\% da receita federal tributária deveria ir para a região, sendo que $2 \%$ seriam destinados ao DNOCS e $1 \%$ para um Fundo Especial, especialmente criado para aliviar os danos causados pelas secas (ROETT, 1971, 22). ${ }^{10}$

Em 1948, foi criada a Comissão do Vale do São Francisco (CVSF). Esta comissão era responsável por aplicar programas de desenvolvimento, relativos ao potencial hidrelétrico da região e a modernização dos transportes no Vale do São Francisco. Entre a as atribuições da CVSF constavam:

\footnotetext{
Orientar e fiscalizar as entidades já existentes no vale, coordenar a ação das unidades administrativas federais, estaduais e municipais, e opinar sobre todo projeto ou execução no vale de obra pública ou particular por iniciativa de qualquer outra entidade pública ou privada (DICIONÁRIO HISTÓRICOBIOGRÁFICO BRASILEIRO. CPDOC. FGV. Verbete Comissão do Vale do São Francisco). ${ }^{11}$
}

\footnotetext{
${ }^{10}$ Artigo 198 da Constituição Federal de 1946: "Na execução do plano de defesa contra os efeitos da denominada seca do Nordeste, a União dependerá, anualmente, com as obras e os serviços de assistência econômica e social, quantia nunca inferior a três por cento da sua renda tributária". Grifo nosso. Disponível em: https://www2.camara.leg.br/legin/fed/consti/1940-1949/constituicao-1946-18julho-1946-365199-publicacaooriginal-1-pl.html Acesso em: 22/04/2019.

${ }_{11}$ DICIONÁRIO HISTÓRICO-BIOGRÁFICO BRASILEIRO. CPDOC. FGV. Verbete Comissão do Vale do São Francisco. Disponível em: http://www.fgv.br/Cpdoc/Acervo/dicionarios/verbetetematico/comissao-do-vale-do-sao-francisco-cvsf Acesso em: 18/04/2019.
} 
Um plano da CVSF, de 1950, por exemplo, cujas obras foram orçadas e previstas para serem executadas de 1952 a 1956, incluíam programas de obras relativos à: 12

[...] regularização do regime fluvial, melhoria dos transportes e comunicações, construção de centrais e usinas hidrelétricas e redes de transmissão, irrigação, saneamento urbano e rural, saúde pública, fomento da produção agrícola, pesquisa sobre aproveitamento de recursos minerais, reflorestamento e incremento da imigração e colonização (ANDRADE de PAULA, 2010, 4).

Outras duas importantes iniciativas para promover o combate aos efeitos das secas e o desenvolvimento da região foram a criação da Companhia Hidroelétrica do Vale do São Francisco (CHESF) - uma empresa mista, na qual o governo federal detinha a maior participação no capital social da empresa - e a Comissão de Investimentos do Nordeste (CIN), submetida ao Ministério de Viação e Obras Públicas, e cuja função era coordenar as atividades e obras públicas na região, além de planejar uma série de estudos de emergência contra as secas. Entre as funções da Comissão, destacam-se a reestruturação dos serviços do DNOCS, a realização de convênios de coordenação e coparticipação das várias entidades públicas interessadas nos problemas de investimento do Nordeste, especialmente do polígono das secas. Estudos básicos sobre as condições geográficas, geológicas, econômica e sociais da região das secas também eram realizados pela instituição. ${ }^{13}$ No entanto, estas iniciativas sofreram interferência dos grupos regionais, tradicionalmente opostos à mudança do status quo na região. Por meio dessa interferência, obras de combate as secas eram construídas de acordo com os interesses pessoais de políticos locais (ROETT, 1971, 23).

Em 1958, uma seca de grandes proporções criou uma onda de migração para as cidades do litoral e outras regiões do Brasil. O grande fluxo migratório dos nordestinos para as cidades acelerou os esforços do governo federal no sentido de melhorar as condições socioeconômicas no Nordeste. Nesse contexto, o Presidente

\footnotetext{
12 Em 1974, a CVSF se tornou a Companhia de Desenvolvimento dos Vales do São Francisco e do Parnaíba (CODEVASF).

${ }^{13}$ Decreto no 36.478 , de 18 de novembro de 1954. Cria a Comissão de Investimentos no Nordeste (CIN) Disponível em: http://www2.camara.leg.br/legin/fed/decret/1950-1959/decreto-36478-18-novembro1954-328052-publicacaooriginal-1-pe.html Acesso em: 24/01/2019.
} 
Juscelino Kubitscheck criou o Grupo de Trabalho do Nordeste (GTDN) com a missão de elaborar um plano de desenvolvimento para a região (ROETT,1971, 30).

Em maio de 1958, o economista Celso Furtado, a pedido do Presidente Kubitscheck, iniciou uma série de estudos para desenvolver uma nova política para o Nordeste. ${ }^{14}$ Esses estudos dariam origem ao relatório intitulado: "Uma Política para o Desenvolvimento Econômico do Nordeste". O relatório destacava o papel da industrialização para a transformação da economia agrícola. Além disso, enfatizava o papel da migração da população de áreas superpovoadas para povoar a área úmida do estado do Maranhão na tentativa de ampliar as fronteiras agrícolas do Nordeste. Essa análise tornou-se base para projetos específicos que seriam posteriormente apresentados nos planos diretores da SUDENE (ROETT,1971, 32; SARZYNSKI, 2008, 11).

Em 1959, o Senado Federal aprovou a criação da Superintendência para o Desenvolvimento do Nordeste (SUDENE). Seu objetivo era tanto o de enfrentar os problemas das secas, quanto o de estimular o desenvolvimento industrial no Nordeste. A Superintendência pretendia reestruturar a economia agrícola na região, por meio da ampliação da oferta de terras e da reorganização da economia do semi-árido (SUDENE. Plano Diretor, 1966, 122-5). Nesse sentido, a SUDENE era diretamente subordinada ao presidente da República. Suas prerrogativas incluíam a coordenação e o controle das atividades e investimentos de outras agências federais no Nordeste, incluindo o DNOCS, a CVSF e o Banco do Nordeste. A SUDENE era dirigida pelo Superintendente - seu chefe executivo e formulador das políticas. Ela contava também com um Conselho Deliberativo composto por 26 membros, dentre eles dez representantes dos nove estados do Nordeste e um de Minas Gerais. (PAGE, 1972, 27; ROETT, 1971, 37; SARZYNSKI, 2008, 11).

Celso Furtado, Superintendente da SUDENE, elaborou o primeiro Plano Diretor da Superintendência. Este plano enfatizava, entre outras coisas, a criação de uma infraestrutura econômica, através do investimento em transportes e energia elétrica. O aproveitamento racional dos recursos da água e a reestruturação da economia agrícola. Fomentar o desenvolvimento industrial da região, o melhor aproveitamento

\footnotetext{
${ }^{14}$ Celso Furtado havia trabalhado para Comissão Econômica para a América Latina (Cepal). Quando foi convidado pelo Presidente Juscelino para ser interventor junto ao GTDN, ele havia acabado de retornar ao Brasil, após um período na London Schooll of Economics (DICIONÁRIO HISTÓRICOBIOGRÁFICO BRASILEIRO. CPDOC. FGV. Verbete Celso Monteiro Furtado).
} 
dos recursos minerais e a redistribuição da mão de obra, por meio de uma política de colonização (SUDENE. Plano Diretor, 1966, 19). Devido a questões agrícolas, como o controle de recursos destinados a programas de irrigação, o Plano Diretor encontrou resistência para ser aprovado pelo Senado. A oposição no congresso veio principalmente da delegação nordestina, que via a passagem do plano como uma ameaça à sua posição de privilégio. Ocorria que as verbas destinadas ao Nordeste "eram liberadas rapidamente com pouca fiscalização do Governo Federal". Isso permitia que "a construção de barragens e açudes, assim como a perfuração de poços e construção de estradas eram, em sua grande maioria, feitas nas propriedades dos grandes fazendeiros". Essa prática ficou conhecida como indústria da seca. Nesse sentido, os representantes dos latifundiários no Senado viam com receio a centralização dos investimentos por meio da SUDENE e, por isso, dificultaram a aprovação do Plano Diretor. Em 1961, finalmente, o Plano Diretor foi aprovado e os fundos destinados à Superintendência começaram a ser liberados (ROETT,1971, 37; BARROS, 2017, 59).

\section{2 - "Entram os Americanos"}

A aprovação da legislação da SUDENE deu fôlego à causa do desenvolvimento regional e coincidiu com a nova abordagem para as relações com a América Latina da administração Kennedy por meio da Aliança para o Progresso. A Aliança pretendia promover o desenvolvimento econômico da América Latina, fortalecer governos democráticos e melhorar as condições materiais da população latino-americana. Seu objetivo era conter a influência de Fidel Castro e da Revolução Cubana no hemisfério. A ligação entre Cuba e a Aliança para o Progresso é fundamental para entender por que o Nordeste se tornou uma prioridade. ${ }^{15}$

Assim, dentro desse contexto, desde muito cedo em seu governo o Presidente Kennedy manifestou interesse em trabalhar com a SUDENE em um programa de desenvolvimento para o Nordeste brasileiro. O presidente norte-americano acreditava

\footnotetext{
${ }^{15}$ Sobre as relações entre a SUDENE e a Aliança para o Progresso ver Riordan Roett, Politics of Foreign Aid, capítulo 05 e Joseph Page, The Revolution that Never Was, capítulo 05. Sobre o interesse do Presidente Kennedy sobre o Nordeste ver esta última obra citada, páginas 27 a 29 e Vandeck Santiago, Pernambuco em Chamas, páginas 57 a 84. Sobre a relação entre a Revolução Cubana e a Aliança para o Progresso ver Moniz Bandeira, De Martí a Fidel: A Revolução Cubana e a América Latina, capítulo X.
} 
que "não havia lugar neste hemisfério em maior ou mais urgente necessidade de atenção do que o vasto Nordeste do Brasil". Segundo autores como Joseph Page (1972, 27), Vandeck Santiago (2016, 57-84) e Arthur Barros (2017, 62-4), as reportagens escritas por Tad Szulc publicadas no The New York Times, em outubro de 1960, tiveram um peso importante na atenção dada pelo Presidente Kennedy ao Nordeste do Brasil. As reportagens faziam crer a região atravessava intensa agitação social. Devido a isso, os acontecimentos poderiam tomar o rumo de uma revolta socialista, semelhante à Cuba. Kennedy afirmou que os Estados Unidos estavam preparados para cooperar com SUDENE "de forma contínua, para ajudar a resolver os problemas do Nordeste e trazer o progresso econômico e social para essa região dura". 16

A primeira ação da administração Kennedy, no sentido de establecer contato com a SUDENE, ocorreu em 12 de fevereiro de 1961. Isso foi antes mesmo do lançamento da Aliança para o Progresso em discurso para os embaixadores latinoamericanos um mês depois. Uma delegação do programa Food for Peace, comandada por George Mcgovern, Diretor do programa, e Arthur M. Schlesinger, Secretário Assistente para Assuntos Latino-americanos, foi enviada ao Brasil para encontrar Celso Furtado e excursionar pelo Nordeste. Na ocasião do encontro, a delegação ofereceu US\$ 70 milhões a serem aplicados em programas para o desenvolvimento do Nordeste e Celso Furtado foi convidado a se encontrar com o Presidente Kennedy nos Estados Unidos. ${ }^{17}$ A delegação também era composta por um conjunto de técnicos da United States Operation Mission (USOM). A USOM era uma agência governamental norte-americana subordinada a International Cooperation Administration (ICA), criada em 1955, dotada de recursos anuais aprovados pelo Congresso para objetivos diversos, dentre eles o de administrar programas de assistência econômica dos Estados Unidos. ${ }^{18} \mathrm{Em}$ cada país que os Estados Unidos tivesse um acordo de cooperação econômica, era criado um grupo

\footnotetext{
16 Statement, President Kennedy, July 14, 1961. John F. Kennedy: statement by the president concerning a Plan for the development of Northeast Brazil. Disponível em: http://www.presidency.ucsb.edu/ws/?pid=8239 Acessado em: 04/01/2018.

17 O programa Food for Peace foi elaborado durante a administração de Dwight D. Eisenhower (19531961) e estava vinculado a Public Law 480. A Lei de Assistência e Desenvolvimento do Comércio Agrícola estabelecia os princípios para exportação de alimentos aos países com déficit na produção a preços acessíveis pagos em moeda própria em vez de dólares (BARROS, 2017, 87).

${ }^{18}$ A International Cooperation Administration (ICA) operou de junho de 1955 a setembro de 1961. Ver: Joseph Stokes, "The International Cooperation Administration," World Affairs, Vol. 119, No. 2, (1956), 35-37.
} 
local da USOM (STOKES, 1956, 35-6). Na ocasião dessa visita, os técnicos da USOM iniciaram um levantamento sobre os problemas do Nordeste e sobre como o governo norte-americano poderia contribuir para o desenvolvimento regional. Após meses de estudo, em dezembro de 1961, os técnicos da USOM elaboraram um relatório com um programa cooperativo para encorajar o desenvolvimento econômico das zonas rurais do Nordeste. O relatório propunha uma série de medidas, como serviços e programas de saúde, educação, para a obtenção de água pura, habitação, eletricidade, transportes e comunicação (ROETT,1971, 32) ${ }^{19}$ Celso Furtado afirmou que essa foi a primeira vez que uma missão norte-americana não foi ao Nordeste para escutar apenas usineiros e latifundiários, representantes da velha elite local. Furtado afirmou aos representantes do Presidente Kennedy que a imagem dos Estados Unidos eram a "pior possível", mas que isso poderia mudar caso fosse retomada a "saga da Política da Boa Vizinhança" de Roosevelt (FURTADO, 1997, cap. 05). ${ }^{20}$

Em julho de 1961, ocorreu o encontro entre o Presidente Kennedy e Celso Furtado na cidade de Washington. Durante a visita, Kennedy anunciou a necessidade de enviar uma missão de estudos para analisar as necessidades regionais e formular um programa de auxílio para o Nordeste. ${ }^{21}$ Ele reafirmou seu desejo de estar associado à implementação do Plano Diretor da SUDENE. Na ocasião, o presidente demonstrou preocupação com o problema da fome, da alta taxa de mortalidade infantil e com os movimentos sociais que se organizavam no Nordeste, especificamente as Ligas Camponesas. ${ }^{22}$ Celso Furtado, em suas memórias, comenta que obter o apoio direto do Presidente Kennedy à SUDENE significou uma vitória. No entanto, ela iria "diluir-se à medida que tudo passasse a depender da maquinaria do Departamento de Estado, a qual tudo subordinaria a suas apreciações da situação geral do Brasil”. O Departamento de Estado pretendia realizar uma parceria que assegurasse às autoridades norte-americanas uma presença desde o nível técnico até o das decisões

\footnotetext{
19 Relatório sobre Levantamento no Nordeste [cópia em português], USOM para Jordão Emerenciano, Dez 11, 1961. Fundo Jordão Emerenciano, Dossiê político Cid Sampaio, Manuscritos, caixa 72.

${ }^{20}$ A obra citada é: Celso Furtado, Obra autobiográfica de Celso Furtado (São Paulo, Paz e Terra, 1997). A versão que consultamos é digital e a paginação não corresponde a mesma da versão impressa, por isso a página não foi indicada no corpo do texto.

${ }^{21}$ Apesar da fala do Presidente, os técnicos da USOM já estavam realizando um levantamento e uma série de estudos sobre o Nordeste, como tratado no parágrafo anterior.

22 O crescimento das Ligas Camponesas será tratado mais adiante, nesse capítulo.

Memorandum of Conversation, John Kennedy, Celso Furtado, Carlos Bernardes, Chester Bowles, Robert F. Woodward, Richard Goodwin, Leonard J. Saccio, Milton Barall, Jul 14, 1961. Foreign Relations of the United States, 1961-1963, Volume XII, American Republics. https://history.state.gov/historicaldocuments/frus1961-63v12/d211 Acesso em 30/11/2017.
} 
finais. Furtado defendia a tese de que que a política era brasileira e de total responsabilidade do governo brasileiro (FURTADO, 1997, cap. 05).

Em outubro de 1961, uma missão especial enviada foi enviada pelos Estados Unidos para realizar estudos no Nordeste. Composta por um time de técnicos liderados pelo embaixador Merwin L. Bohan, ela viajou pelo Nordeste conferenciando com membros do governo federal e estaduais, líderes locais e com membros da equipe da SUDENE. ${ }^{23}$ Como resultado, apresentou um relatório. O "Northeast Brazil Survey Team Report' fez uma análise geral do Nordeste. Diversos elementos do relatório Bohan (como ficou conhecido o Survey Team Report) seguiam as recomendações do relatório da USOM. O relatório apresentava medidas de curto e longo prazo. No curto prazo, recomendava programas na rede de abastecimento de água para populações pobres através da construção de chafarizes públicos ou cacimbas para abastecimento aos marginalizados; redes de distribuição de água em determinadas cidades interioranas e cacimbas para as pequenas comunidades; prgramas de eletrificação rural, unidades de saúde moveis e ensino de medidas higiênicas. Todos os projetos deviam ostentar visivelmente os símbolos da Aliança para o Progresso. No longo prazo, recomendava conjugar as atividades norteamericanas aos esforços das autoridades brasileiras, canalizando recursos através da SUDENE (SANTIAGO, 2016, 127). Segundo o brasilianista Riordan Roett (1971), o embaixador Bohan teria afirmado, em entrevista ao autor, que recomendara que o tamanho da presença da USAID no Nordeste fosse mínimo - portanto a missão da USAID deveria ter apenas um pequeno número de especialistas. A SUDENE seria a responsável por implementar os projetos.

Nesse período, a administração Kennedy dava sinais de pressa para ver os resultados da Aliança. O novo embaixador norte-americano para o Brasil, Lincoln Gordon, chegou ao país afirmando à imprensa que a Aliança para o Progresso "seria um programa de ação rápida, capaz de responder à ameaça comunista que espreitava o Nordeste" (CORREIO DA MANHÃ, 14/10/1961, p. 12). No início de 1962, Fowler Hamilton, Administrador da Agência para o Desenvolvimento Internacional (AID), em

\footnotetext{
${ }^{23}$ Merwin L. Bohan foi oficial do Serviço de Relações Exteriores de 1928 a 1955. Foi Conselheiro de Assuntos Econômicos da Embaixada dos Estados Unidos na Cidade do México, de 1945 a 1949 e Embaixador no Conselho Econômico e Social Interamericano de 1951 a 1955. Era, portanto, um especialista em programas de assistência para o desenvolvimento da América Latina e por isso foi encarregado pelo Presidente Kennedy de chefiar o grupo que deveria elaborar um plano para o Nordeste.
} 
correspondência ao Presidente Kennedy, o informou que, antes das eleições de outubro de 1962 que ocorreriam no Brasil, seriam concluídos acordos para o Nordeste e que se esperava iniciar projetos em outros lugares do Brasil. Os programas visavam impacto imediato, tinham propósito social e eram direcionados aos centros de maior descontentamento no Nordeste. ${ }^{24}$

Finalmente, em abril de 1962, Brasil e Estados Unidos assinaram o "Acordo do Nordeste". Por meio desse acordo, os Estados Unidos se comprometiam a investir o valor de US\$131 milhões (US\$ 831 milhões em valores atualizados pelo Indíce de Preços do Consumidor dos Estados Unidos), no Nordeste. Este acordo foi resultado dos estudos elaborados por Celso Furtado e pelas recomendações do Relatório Bohan (DIÁRIO DE PERNAMBUCO, 14/04/1962, p.1). ${ }^{25} \mathrm{O}$ acordo definia que 0 governo norte-americano suplementaria os esforços do Brasil no desenvolvimento do Nordeste. Para tanto, deveriam executar um programa de ação imediata destinado a obter resultados rápidos na satisfação das mais urgentes necessidades do povo do Nordeste. Tais projetos, destinados a produzir benefícios imediatos, eram os incluídos no relatório do grupo de estudos ou no Plano Diretor da SUDENE, ou que pudessem vir a ser mutuamente acordados (ROETT, 1972, 82-6; SANTIAGO, 2016, 116-18).

A SUDENE e a United States Agency of International Development (USAID) foram as agências escolhidas para administrar os recursos do acordo. O Acordo do Nordeste autorizava o estabelecimento de um escritório da USAID em Recife, já que a sede da SUDENE estava localizada em Pernambuco. A SUDENE estava autorizada a concluir acordos sobre projetos e empréstimos. "As atividades compreendidas nesses projetos poderiam ser administradas pela SUDENE ou por qualquer outra repartição ou órgão escolhido por mútuo acordo". Nos casos que fossem indicados pelo governo brasileiro, outras repartições poderiam ser autorizadas a concluir acordos sobre projetos, ou outros diretamente com a USAID, sendo autorizadas a receber empréstimo ou donativos (ROETT, 1972, 82-6; SANTIAGO, 2016, 116-18).

Riordan Roett (1971, 82-3) destaca que a principal dificuldade no início da Aliança para o Progresso, no Nordeste, estava na interpretação da possibilidade de a

\footnotetext{
24 Memorandum, Fowler Hamilton to President Kennedy, Feb 9, 1962. Memorandum from the Administrator of the Agency for International Development (Hamilton) to President Kennedy. Washington, FRUS, Volume XXI, American Republics, Document 220. Disponível em: https://history.state.gov/historicaldocuments/frus1961-63v17/d249 Acesso em: 04/12/2017.

25 Para a conversão dos valores do Acordo do Nordeste em valores atualizados, foi utilizado o site Measuring Worth. Disponível em: https://www.measuringworth.com/ Acesso em: 24/07/2018.
} 
USAID realizar acordos sem a anuência da SUDENE. Os Estados Unidos interpretavam que podiam celebrar acordos com outras agências brasileiras sem a participação da SUDENE. Esta, por sua vez, entendia que para manter sua posição na região, ela própria deveria aprovar, estar envolvida, ou designar a agência competente em todos os projetos. "Para os Estados Unidos, o acordo significava que eles poderiam começar a combater diretamente a ameaça comunista que haviam identificado no Nordeste" (ROETT apud PAGE, 1972, 95). ${ }^{26}$ O governo norteamericano utilizou essa interpretação para estabelecer acordos diretos com governos estaduais, sem a participação da SUDENE.

Nesse sentido, Pernambuco foi o primeiro estado a celebrar acordos diretos com o governo dos Estados Unidos. Ainda em 1961, ao mesmo tempo que os técnicos da USOM realizavam estudos no Nordeste, um deles, com experiência em assuntos educacionais brasileiros, tinha a função de elaborar um plano para a construção de escolas no estado do Rio Grande do Norte. O embaixador Lincoln Gordon rejeitou o local (ROETT, 1972, 92). A embaixada resolveu ir adiante com o projeto em Pernambuco. O motivo seria que as forças democráticas, supostamente representadas pelo governador Cid Sampaio, necessitavam de ajuda dos Estados Unidos. Com a proximidade das eleições de 1962, a estratégia era tentar um rápido programa que fornecesse alguma evidencia tangível de progresso, beneficiando o candidato que seria representado pelas forças de Cid Sampaio - no caso, João Cleofas - para se opor a Miguel Arraes no pleito para governador (ROETT, 1972, 92).

$\mathrm{Na}$ seção a seguir, analisamos as características e particularidades sociais e políticas de Pernambuco. Busca-se entender quais eram as características de Pernambuco, no final dos anos 1950 e inicio dos anos 1960, que motivaram os acordos entre o governo do estado e os Estados Unidos no âmbito da Aliança para o Progresso.

\section{3 - Pernambuco: política, economia e sociedade.}

A Região Metropolitana do estado de Pernambuco é formada pela capital Recife e outras cidades como Paulista e Olinda. Durante os períodos de seca, esta região recebia um grande número de retirantes. O agreste pernambucano - área de

\footnotetext{
${ }^{26}$ Declaração originalmente publicada em: Riordan Roett, Economic Assistance and Political Change: The Brazilian Northeast (University Microfilms, Ann Arbor, Mich., 1968), p. 12. Publicado como Political Change and Economic Assistance in the Brazilian Northeast pela Vanderbilt University Press.
} 
transição entre a faixa húmida e o sertão semiárido - era uma região de produção de algodão, com alguns minifúndios de subsistência. A pecuária praticada ali fornecia alimentos para as regiões metropolitana e da Mata. O sertão de Pernambuco é a área do semiárido que, devido às estiagens agudas, enfrentava problemas como a fome e o deslocamento de sua população para a região metropolitana (BARROS, 2017, 57).

A Zona da Mata foi a região mais importante, do ponto de vista econômico, do estado de Pernambuco durante séculos. Esta região possui duas subdivisões distintas - o Norte seco e o Sul húmido -, sendo que a região Sul era a área mais adequada à lavoura do açúcar. Desse modo, no início do século XIX, era no Sul que estavam os engenhos mais prósperos e com maior quantidade de escravos. No norte, onde 0 número de escravos era menor, encontravam-se também índios, mulatos e negros livres (ABREU e LIMA, 2005, 23).

Imagem 2: Mesorregiões de Pernambuco: sertão, agreste, Zona da Mata e Região Metropolitana de Recife (RMR)

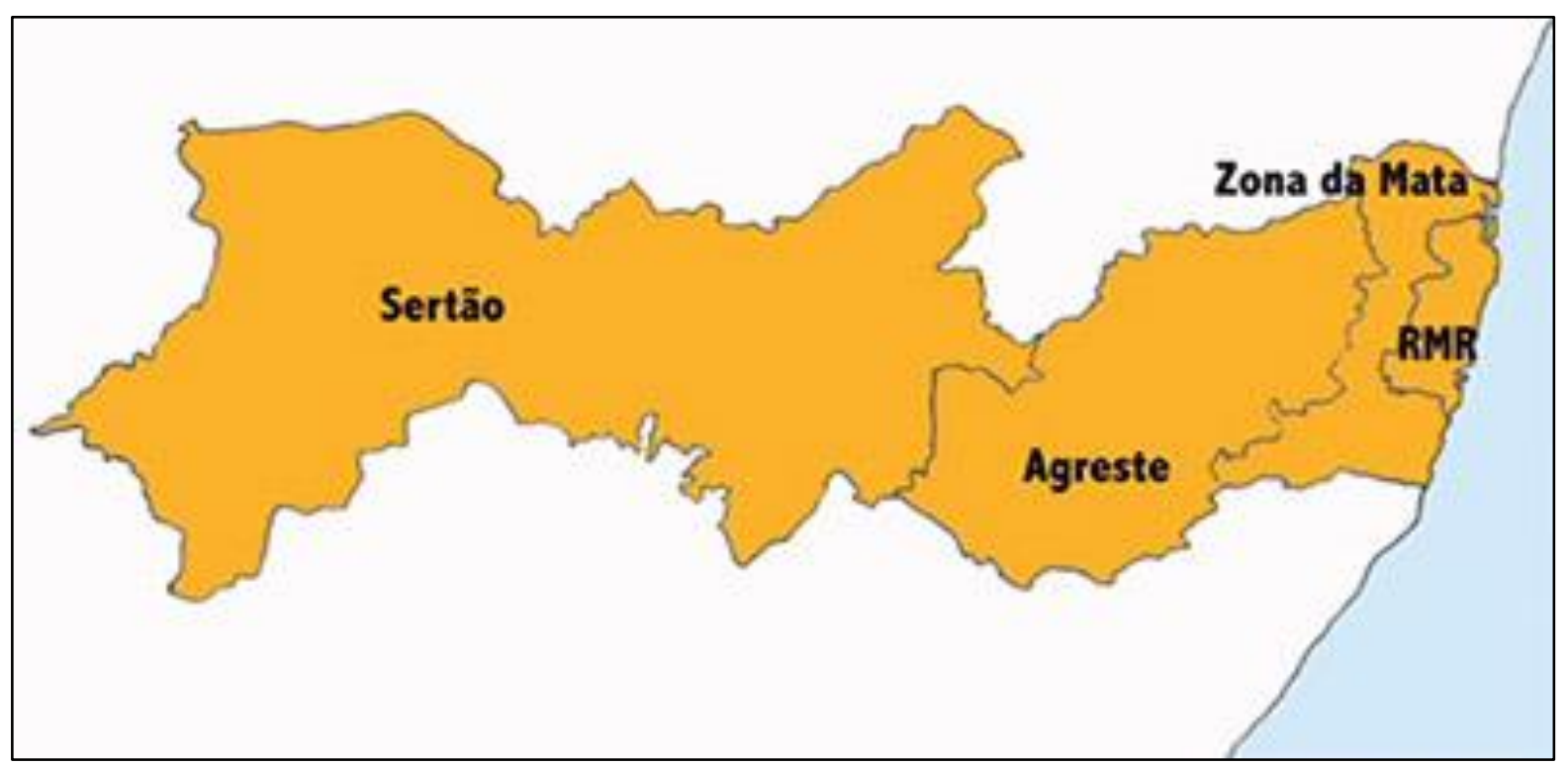

Fonte: Arthur Victor Gonçalves de Barros, A pobreza como estopim da revolução: a Aliança para o Progresso em Pernambuco (1959-1964) (Tese de Dissertação, Recife: UFPE, 2017), p. 57.

Na segunda metade do século XIX, as restrições à escravidão aumentaram o número de trabalhadores livres nos engenhos de açúcar. Os trabalhadores desses engenhos levantavam uma "choupana" e estabeleciam um pequeno roçado na propriedade e, em troca, trabalhavam dois ou três dias por semana para o senhor de engenho, gratuitamente ou por um salário muito baixo. $\mathrm{O}$ trabalho gratuito prestado ao dono da propriedade era chamado de "cambão". Foi só nos anos 1950 que os trabalhadores rurais começaram a se organizar, fazendo com que o número de 
trabalhadores agrícolas assalariados se tornasse expressivo (ABREU e LIMA, 2005, 23).

A historiadora Maria do Socorro de Abreu e Lima $(2005,24)$ explica que esses trabalhadores rurais não podiam produzir tudo o que consumiam, ganhando muito pouco como assalariados, assim, tinham que complementar suas necessidades se abastecendo no barracão do engenho. Era comum que o trabalhador rural ficasse devendo ao barracão e tivesse que tomar um empréstimo do patrão. Alguns trabalhadores eram obrigados a trabalhar durante o dia para pagar sua dívida, enquanto ficavam presos durante a noite. Apesar de haver leis que protegiam 0 trabalhador rural - o Estatuto da Lavoura canavieira, de 1941, por exemplo, concedia ao trabalhador rural salário mínimo e a CLT dava-Ihes direito a férias -, na prática esses direitos não eram efetivados.

A violência era uma prática comum nos engenhos. Trabalhadores rurais podiam ser espancados até a morte por chupar um pedaço de cana, ou serem expulsos da propriedade, perdendo sua plantação, sem receber nenhuma indenização. Nesse ambiente, onde a injustiça imperava, Abreu e Lima (2005, 25-7) destaca que "a situação geral da mulher no campo era de total dependência". A mulher casada tinha muitos filhos e era sustentada pelo marido. Na condição de viúva, podia ser expulsa do engenho com os filhos. Havia também a preocupação em "tirar do engenho a moça desvirginada". Se a mulher não encontrasse alguma solidariedade no seio da família, ela teria grande dificuldade para sobreviver. Diante de tanta violência e injustiças, posicionar-se contra era muito arriscado. Desse modo, "a dominação se dava pelo uso da força e pelo mandonismo dos senhores de engenho e coronéis do interior que exerciam o poder e controlavam as instituições sociais e políticas".

Ainda assim, na segunda metade da década de 1950, a mobilização dos trabalhadores rurais por melhores condições de vida ganhou fôlego e passou a ser tema da imprensa. Nesse mesmo período, ocorria uma crise nos preços do açúcar. São Paulo ultrapassou a produção açucareira pernambucana. Os proprietários reduziram suas atividades e os trabalhadores rurais contornaram a situação retomando a cultura de subsistência (ABREU e LIMA, 2005, 28).

Abreu e Lima $(2005,28)$ argumenta que, nesse período, "foi sendo levado a efeito a proletarização no campo, à medida que os trabalhadores rurais foram perdendo seus sítios e roçados, tornando-se em assalariados rurais". Nesse contexto, "a relação entre agregado e proprietário foi ficando mais clara, deixando de existir 
determinados mascaramentos que a encobriam". A organização das Ligas Camponesas seriam uma reação a esse processo.

A primeira Liga Camponesa surgiu quando moradores do engenho Galileia, em Vitória de Santo Antão, município de Pernambuco, localizado na região da Mata, formaram a Sociedade Agrícola e Pecuária dos Plantadores de Pernambuco (SAPPP). Essa entidade nasceu com fins assistenciais. Dentre estes, o de fornecer auxílio funerário, uma vez que, quando morria um trabalhador, este era velado em um caixão da prefeitura, que depois era devolvido para ser reutilizado. O corpo era enterrado em um buraco. Essa prática inspirou o título do livro "sete palmos de terra e um caixão" de Josué de Castro, e se refere ao desejo dos trabalhadores rurais de terem direito a um caixão e a um enterro decente. Oscar Beltrão, dono do engenho Galileia, que de início apoiou a associação e foi nomeado seu presidente de honra, ao ser alertado sobre o caráter "subversivo" da associação, ordenou sua dissolução. Os trabalhadores rurais não acataram as ordens do patrão e, na buscaram a ajuda do advogado e deputado estadual Francisco Julião, do Partido Socialista Brasileiro (PSB) (ABREU e LIMA, 2005, 28; BARROS, 2017, 60-1).

Francisco Julião passaria então a ser o principal líder da Liga Camponesa. A luta que se seguiu terminou com a aprovação, em 1959, do projeto de lei de desapropriação do Engenho Galileia. Esta foi a primeira vez em que houve uma desapropriação para fins de reforma agrária no Brasil. Seguindo o exemplo dos moradores do engenho Galileia, outras Ligas Camponesas surgiram no Nordeste, principalmente no estado da Paraíba, o que elevou o nível de atenção, tanto das elites locais, quanto dos Estados Unidos. Em 1961, as Ligas contavam com cerca de 10 mil associados, distribuídos em 40 delegacias, no estado de Pernambuco (ABREU e LIMA, 2005, 28; BARROS, 2017, 60-1). ${ }^{27}$

A base das Ligas Camponesas era formada por "pequenos arrendatários, parceiros, minifundistas e moradores dos engenhos, que reivindicavam, além do direito de permanecerem na terra, o pagamento das benfeitorias feitas por eles". 0 nome Ligas Camponesas foi atribuído pela imprensa para caracterizá-los como

\footnotetext{
${ }_{27}$ Nos anos 1960, as Ligas se organizavam em delegacias ou núcleos, por munícipios, distritos ou fazendas. Localmente, eram compostas apenas por camponeses. A entidade estadual, com sede na capital, era regida por um estatuto único e dirigida por um conselho deliberativos de 13 membros. "Além das principais lideranças camponesas, haviam parlamentares, profissionais liberais e estudantes" na composição do conselho deliberativo (ABREU e LIMA, 2005, p. 30).
} 
comunistas, em referência as organizações populares de mesmo nome organizadas pelo PCB na década de 1940 (ABREU e LIMA, 2005, 30).

Segundo Abreu e Lima (2005, 31), no início dos anos 1960, as Ligas Camponesas sofreram grande influência da Revolução Cubana, o que acarretou "uma grande virada política e ideológica". As Ligas passaram a considerar ser possível alcançar o socialismo sem etapas, em oposição a visão do Partido Comunista do Brasil (PCB), para quem o socialismo deveria ser atingido através do jogo democrático, em aliança com a burguesia nacional. Essa virada ideológica se deu após a visita de Francisco Julião à Cuba em 29 de março de 1960. ${ }^{28}$ Após a tentativa de invasão de Cuba pelo governo Kennedy, em 1961, as Ligas iniciaram treinamentos de guerrilha em Dianópolis, Goiás (ABREU e LIMA, 2005, 33). O campo de treinamento acabou ocupado pelas forças armadas pouco tempo depois, mas exemplifica a mudança no direcionamento político e ideológico das Ligas.

Bernard José Pereira Alves $(2018,208-12)$, argumenta que as Ligas Camponesas tiveram um relacionamento próximo a Fidel Castro. Segundo o autor, o próprio Fidel sugeriu uma reorganização na estrutura da organização. As ligas deveriam ter três estruturas: a militar, a política e a das massas, lideradas respectivamente por Adalto Freire, Clodomir Morais e Francisco Julião. Moniz Bandeira $(1998,305)$ afirma que o governo cubano "sustentou" as Ligas Camponesas e "forneceu-lhe os recursos para a luta armada no Nordeste".

A partir de novembro de 1961, com o Congresso Camponês de Belo Horizonte, houve um acirramento das tensões entre as Ligas Camponesas e o PCB, este acabou por expulsar de seus quadros os simpatizantes das Ligas. ${ }^{29}$ A partir de 1962, duas lideranças se destacam no interior das Ligas. Além de Francisco Julião, Clodomir Morais vai desempenhar um importante papel de liderança. Clodomir Morais era mais alinhado a ideia de resistência armada, proposta por Fidel, enquanto Julião pretendia ampliar as bases do movimento aumentando o número de Ligas ao redor do país (ALVES, 2018, 210-14). ${ }^{30}$

\footnotetext{
${ }^{28}$ Julião integrava uma comitiva que acompanhava o então candidato à presidência da República Jânio Quadros.

${ }^{29}$ Esse congresso ocorreu em novembro de 1961, foi organizado pela União dos Lavradores e Trabalhadores Agrícolas do Brasil (ULTAB). O principal tema debatido foi a reforma agrária e ficou marcado pelas divergências entre a ULTAB, controlada pelo Partido Comunista Brasileiro (PCB), e as Ligas Camponesas (DICIONÁRIO HISTÓRICO-BIOGRÁFICO BRASILEIRO. CPDOC. FGV. Verbete Congresso de Lavradores e Camponeses sem terra).

${ }^{30}$ Sobre as disputas internas das Ligas Camponesas ver: Bernard José Pereira Alves. "Revisitando as ligas camponesas: lideranças e disputas internas do movimento camponês," REVISTA IDEAS
} 
Esses acontecimentos faziam de Pernambuco um dos estados com maior mobilização social e de maior potencial revolucionário. Os trabalhos de Joseph Page (1971), Pablo Porfírio Dias (2008), Vandeck Santiago (2016) e Arthur Victor Gonçalves Gomes de Barros (2017) convergem nesse sentido. Para esses autores, na década de 1950 e início de 1960, a mobilização social e o potencial processo revolucionário eram estimulados pela extrema pobreza. Para eles, o estado de Pernambuco foi representado como "um lugar perigoso, onde a pobreza somada à atuação de grupos de esquerda estaria produzindo desordem social e preparando uma revolução comunista" (PORFÍRIO, 2008, 12).

As condições de vida da população pobre de Pernambuco e, especificamente do Recife, chamavam a atenção da imprensa nacional e internacional. Recife era tida como a quarta pior cidade do mundo, superada apenas por três cidades africanas, em termos de pobreza e desigualdade (CASTRO, 1984, 11). Vandeck Santiago (2016) e Arthur Barros (2017) destacaram em seus trabalhos que a cobertura da imprensa sobre as condições sociais no estado teria sido uma das motivações da criação do programa Aliança para o Progresso. Ambos autores concordam que a série de reportagens produzidas, em outubro de 1960, pelo correspondente do New York Tymes, Tad Szulc, teriam grande influência sobre a opinião pública norte-americana e, também, sobre o Presidente John Kennedy.

Barros (2017, p. 62-3) destaca o tom sensacionalista reproduzido pelo jornalista do New York Times. A primeira reportagem, de 31 de outubro, cuja manchete era "Pobreza no Nordeste do Brasil gera ameaça de revolta", teria representado uma "situação caótica em pleno desenvolvimento, com possível desdobramento revolucionário". A segunda reportagem da série, intitulada "Marxistas estão organizando camponeses no Brasil", acusava os comunistas de "aproveitarem a situação de miséria em seu favor". O resultado dessa série jornalística foi que Pernambuco "passou a ser conhecido como o centro do comunismo no Brasil" e isto teria despertado notório interesse pela região por parte do governo norte-americano.

Barros $(2017,63)$ cita, ainda, outro exemplo de cobertura da imprensa, que conferiu destaque a Pernambuco e às Ligas Camponesas. A revista Life, em edição de 1961, trouxe Fidel Castro na capa e quatro páginas dedicadas a representar as Ligas Camponesas e "um cenário de extrema pobreza que favoreciam os caminhos

(ONLINE), v. $\quad$ v, (2018), p. 202-224, acesso 03/02/2019,


da revolução comunista" em Pernambuco. Santiago $(2016,67)$ afirma que, nos anos 1960, as matérias publicadas com destaque em grandes veículos de comunicação, como o New York Times, "possuíam a capacidade de interferir na história e modelar a política externa norte-americana".

Nesse sentido, a historiadora Sarah Sarzynski $(2008,12)$ concorda que "quando as Ligas Camponesas despertaram interesse mundial, observadores estrangeiros foram rápidos em assumir que a revolução no Nordeste poderia provocar revoltas no resto do país". Para a autora, as Ligas Camponesas foram vistas, pelos Estados Unidos, nos termos da Guerra Fria e da Revolução Cubana. No entanto, como destaca Joseph Page $(1972,10)$, e como frisa a autora, "a questão relevante na época não era se Francisco Julião era outro Castro, mas se ele poderia se tornar outro Padre Cícero ou Antônio Conselheiro". Isso é o mesmo que dizer que as duras condições de vida dos camponeses das Ligas os tornariam mais propensos aos apelos de líderes messiânicos do que de um líder revolucionário como Fidel Castro ou Che Guevara. Em suma, para esses autores, os Estados Unidos erraram ao interpretar os camponeses das Ligas como propensos a revolução socialista e ao marxismo.

Na capital de Pernambuco, Recife, o problema mais impactante, na visão dos jornalistas que visitaram a cidade nos anos 1960, era a questão dos "mocambos". Estes eram uma espécie de habitação miserável construída às margens dos rios e próximas do mar. Josué de Castro $(1975,102)$ descreveu as condições de vida dos habitantes desses mocambos por meio do "ciclo do caranguejo". De acordo com este autor, os habitantes dos mocambos viviam em meio a "lama misturada com urina, excremento e outros resíduos que a maré traz". Eles viviam e se alimentavam do caranguejo, e, portanto, dessa mesma lama. Suas fezes misturadas à lama serviam de alimento aos caranguejos e, estes, serviam de alimento ao homem. Dê acordo com este mesmo autor, "dos 700 mil habitantes que o Recife possuía, 230 mil viviam em habitações do tipo de mocambos". A população que vivia em mocambos era maior que a população de qualquer outra cidade brasileira, "exceto uma meia dúzia: Rio, São Paulo, Recife, Salvador, Porto Alegre e Belém” (CASTRO, 1984, 141).

O problema habitacional era agravado durante os períodos de seca, quando o fluxo migratório para as cidades aumentava, devido à fuga dos retirantes. Ainda no final da década de 1930, o problema dos mocambos motivou a criação da Liga Social Contra os Mocambos, em contexto de intervenção do governador Agamenon 
Magalhães, cujo objetivo era o de construir casas nas quais os habitantes dos mocambos pudessem comprar. A Liga inspirou a criação do Serviço Social contra o Mocambo (SSCM) em 1945. A USAID assinaria, em 05 de outubro de 1962 - portanto as vésperas das eleições estaduais - um acordo para a construção de casas em Pernambuco com o Serviço Social Contra o Mocambo (SSCM) (PANDOLFI, 1984, 61; BARROS, 2017, 114).

Todo esse contexto socioeconômico apresentado, de crescimento dos movimentos sociais, representados pelas Ligas Camponesas, e de agravamento da miséria, como demostra o crescimento dos mocambos e os efeitos da seca, são considerados pelos autores citados como elementos que teriam despertado a atenção dos Estados Unidos para o estado de Pernambuco. Soma-se a estes fatores a variável política. Em outubro de 1962, a candidatura de Miguel Arraes (PST) foi interpretada pelos Estados Unidos como uma ameaça. Na visão dos agentes públicos do governo norte-americano, Arraes seria um político perigoso devido a seus laços com a esquerda e os comunistas.

Nesse sentido, Joseph Page $(1972,89)$ chama a atenção para a situação da política doméstica dos Estados Unidos. A administração Kennedy, em seu primeiro ano de mandato, havia sofrido o fiasco da baía dos Porcos. ${ }^{31}$ A Revolução Cubana havia se deslocado para uma linha abertamente Marxista-Leninista. Diante desses fatos, os democratas enfrentavam acusações de que haviam perdido Cuba. "O brilho liberal da administração Kennedy não podia sobreviver a qualquer coisa que sugerisse ser outra perda", e, portanto, evitar a eleição de Arraes era visto como fundamental para manter Pernambuco e o Nordeste a salvo do comunismo.

Ruth Leacock (1999, cap. 06) vê nas eleições de outubro de 1962 uma clara tentativa de manipulação dos resultados por parte dos Estados Unidos, submetendo o desejo dos eleitores aos interesses da Casa Branca. A autora destaca que fundos da Aliança foram usados na região Nordeste em projetos que favorecessem candidatos pró-Estados Unidos com o aval pessoal do Presidente Kennedy. Page

\footnotetext{
${ }^{31} \mathrm{Em}$ abril de 1961, um grupo de exilados cubanos anti-Castro realizou uma tentativa frustrada de invasão à Cuba sob patrocínio do governo norte-americano. Sobre a tentativa de invasão na baía dos Porcos ver: Luiz Alberto Moniz Bandeira, De Martí a Fidel: a Revolução Cubana e a América Latina (Rio de Janeiro, Civilização Brasileira, 2009), capítulo X.
} 
(1972, p. 95) também afirma que a Aliança para o Progresso foi usada para conter o crescimento político de Miguel Arraes. ${ }^{32}$

No entanto, Page $(1972,25)$ descreve Miguel Arraes como "um homem de esquerda, nacionalista e defensor declarado de uma mudança radical por meios legais". Uma análise mais profunda do panorama da política de Pernambuco revela que a situação era complexa e, desse modo, deve ser considerada para além da interpretação dicotômica apresentada pela visão da Guerra Fria. Nesse sentido, a seção a seguir aborda a complexidade da política no estado de Pernambuco e a posição dos principais líderes políticos do estado no espectro político-partidário do período.

\section{4 - Agamenon Magalhães, a Oligarquia Pessedista e os demais partidos em Pernambuco.}

Para compreender a organização dos partidos políticos em Pernambuco, é fundamental abordar a influência política de Agamenon Magalhães. Este político ocupou cargos de elevada importância durante os governos de Getúlio Vargas (193045/1951-54). Ele foi Ministro do Trabalho (1934-1937) e Ministro da Justiça (193706/1937) de Vargas. Agamenon foi o grande nome com quem Vargas pôde contar para implementar diretrizes do Estado Novo em Pernambuco (PANDOLFI, 1984, 44). ${ }^{33}$

No caso especifico de Pernambuco, a instauração do Estado Novo afastou a antiga elite econômica estadual dos senhores de engenho da Zona da Mata do poder. Esta elite era representada pelo interventor Carlos Lima Cavalcanti (1930-37) - um importante líder da Revolução de 1930 (PANDOLFI, 1984, 44). ${ }^{34}$

Em 1935, uma tentativa de golpe contra Vargas, com o apoio do Partido Comunista, foi sufocada. Recife foi uma das cidades onde os comunistas se

\footnotetext{
32 Em 15 de setembro de 1963, após denúncias de Miguel Arraes, foi instaurada a CPI do IBAD. O motivo foi que, nas eleições de outubro para o Congresso Nacional e para governador de alguns estados, os Estados Unidos gastaram uma grande soma de dinheiro apoiando candidatos próamericanos e anti-Goulart através do Instituto Brasileiro de Ação Democrática (IBAD) e do Instituto de Pesquisas e Estudos Sociais (IPES), ambos financiados pela CIA, via empresas nacionais e estrangeiras. A CPI do IBAD foi interrompida após o Golpe de 1964 (IBAD: INTERFERÊNCIA DO CAPITAL ESTRANGEIRO NAS ELEIÇÕES DO BRASIL, 2016, p. 23-5).

${ }^{33} \mathrm{Em}$ 1937, Getúlio Vargas instaurou uma ditadura de caráter populista e inspiração fascista chamada Estado Novo. Durante o Estado Novo, os estados eram governados por interventores nomeados por Vargas.

${ }^{34}$ A Revolução de 1930 afastou a Oligarquia Cafeeira do poder central e pôs fim à Primeira República, dando início ao governo Vargas.
} 
rebelaram. A revolta comunista fez com que Carlos Lima Cavalcanti perdesse prestígio junto ao governo Vargas. "Acusado de conivência com os comunistas", ele foi substituído por Agamenon Magalhães, no comando do estado, em dezembro de 1937. Segundo Dulce Pandolfi (1984, 44-5), sob a liderança de Agamenon Magalhães, a vida política pernambucana seria totalmente reestruturada. Os coronéis do interior ganharam importância e os sindicatos e a igreja seriam cooptados para o esquema político do Estado Novo. ${ }^{35}$

Em 1945, diante da perspectiva de redemocratização, Agamenon Magalhães retornou ao Ministério da Justiça para chefiar os trabalhos de criação do novo codigo eleitoral (PANDOLFI, 1984, 92). Nesse momento de formação de uma nova ordem democrática, marcada pelo fim do Estado Novo, a organização dos partidos políticos passaria a ser uma preocupação chave. Foram fundados o Partido Social Democrático (PSD), a União Democrática Nacional (UDN), o Partido Trabalhista Brasileiro (PTB) e - Partido Comunista Brasileiro (PCB), que funcionou de 1945 a 1947, quando novamente teve sua organização proibida.

Em maio de 1945, foi criado o novo sistema partidário brasilieiro. A partir de esforços dos interventores estaduais, surgiu dentro da máquina estadonovista 0 embrião do Partido Social Democrata (PSD). O PSD foi um partido criado de cima para baixo e foi organizado sob a chefia dos interventores estaduais do Estado Novo (PANDOLFI, 1984, 96). Conquanto os interventores discordassem da forma de se estruturar o partido - "Amaral Peixoto (RJ), Agamenon Magalhães (PE) e Henrique Dosdworth (DF) defendiam a formação de um partido político de caráter nacional". Fernando Costa (SP) e Benedito Valadares (MG) eram favoráveis a formação de partidos fortes regionalmente (HIPPOLITO, 1985, 120-21) - Getúlio Vargas foi nomeado presidente do partido e Agamenon Magalhães estava na linha de frente, entre seus principais líderes (PANDOLFI, 1984, 96). ${ }^{36}$

Em Pernambuco, foi o interventor Etelvino Lins - indicado por Agamenon, quando este assumiu o Ministério da Justiça - o responsável pela criação do PSD. 0 governo usou a estrutura administrativa existente para consolidar o partido. Órgãos administrativos, entidades sindicais e imprensa foram colocados a serviço da causa

\footnotetext{
35 Em 1935, A Aliança Nacional Libertadora (ALN), com apoio do Partido Comunista do Brasil, debelou um levante contra Getúlio Vargas. A tentativa de golpe foi sufocada e Vargas governou o país sob decreto de estado de sítio até 1937, quando instaurou a ditadura do Estado Novo.

${ }^{36}$ Sobre a criação do PSD a nível nacional ver: Lucia Hippolito, De raposas e reformistas - o PSD e a experiência democrática brasileira (1945 - 64) (Rio de Janeiro: Paz e Terra, 1985).
} 
partidária. O partido foi constituído de tal forma a assegurar o apoio dos líderes munícipais mais importantes ao partido. O PSD garantia seu apoio e o direito de nomear autoridades locais em troca dos votos da municipalidade no partido. Agamenon Magalhães foi escolhido presidente da comissão executiva estadual (PANDOLFI, 1984, 96).

O PSD era composto marjoritariamente por membros da burocracia estatal e por coronéis do Agreste e do Sertão, sobretudo aqueles vinculados à oligarquia algodoeira e pecuarista. "Do grande coronel ao pequeno produtor, o mundo rural se articulava no PSD”. Entretanto, era na capital pernambucana que estava a fraqueza do partido. No Recife, a oposição conseguia sair vitoriosa nos pleitos. Ainda assim, a quantidade de votos do interior era superior o suficiente para garantir a vitória, mesmo perdendo na capital (PANDOLFI, 1984, 97-8).

Em Pernambuco, o PSD foi o único partido a dominar a legislatura federal e estadual. Além disso, o partido venceu as eleições para cargos executivos a nível estadual e na capital em 1947, 1950, 1952 e 1954, sendo derrotado apenas em 1958 para o governo estadual. Isso fazia do PSD o partido a ser batido em Pernambuco (PANDOLFI, 1984, 99).

Nesse sentido, a União Democrática Nacional (UDN) foi o principal partido a fazer frente a hegemônia pessedista em Pernambuco. A nível nacional, a UDN congregava setores heterogêneos que se opunham à Vargas. Dentre eles, se destacavam grupos oligárquicos retirados o poder pela revolução de 1930; apoiadores de Vargas, marginalizados pelo seu governo em 1937; membros do Estado Novo, que se afastaram do governo antes de 1945; e as esquerdas em geral (PANDOLFI, 1984, 104). ${ }^{37}$

Em Pernambuco, a UDN tinha como principal característica a oposição a Agamenon Magalhães. Nesse estado, em alguns momentos, por questões regionais, a UDN chegou a apoiar Vargas para combater o PSD, contrariando determinações do partido à nível nacional (PANDOLFI, 1984, 105). Em Pernambuco, os principais membros da UDN eram:

"a-) representantes da oligarquia Estácio Coimbra, destronado do governo com a revolução de 1930 - Samuel Hardman, Júlio Bello,

\footnotetext{
${ }^{37}$ Sobre a criação da UDN ver: Maria V. Benevides, A UDN e o udenismo: Ambiguidades do liberalismo brasileiro. (Rio de Janeiro: Paz e Terra, 1981).
} 
Sérgio Loreto Filho, Aníbal Fernandes e outros; b-) antigos aliados da revolução de 30 que se marginalizaram durante o processo ou mais precisamente com o golpe de 37, como o ex-governador Lima Cavalcanti, João Cleofas, Thomas Lobo, Luiz Cedro, Alde Sampaio, Edgar Teixeira Leite, Severino Mariz, Osório Borba" (PANDOLFI, 1984, 105).

A UDN pernambucana possuia representatividade entre as camadas médias tradicionais, moralistas e anti-Estado Novo. Reunia em suas fileiras os setores vinculados ao capital financeiro, os grandes usineiros do estado. Dentre estes se destavam:

"Costa Azevedo (Usina Catende), Bandeira e Mello (Usina Mussurepe), Pessoa de Queiroz (Usina Santa Teresinha), Alde, Lael e Cid Sampaio (Usina Roçadinho), João Cleofas de Oliveira (Usineiro no estado do Rio Grande do Norte e senhor de engenho em Pernambuco), Lima Cavalcanti (Usina Pedrosa) além da penetração na capital pernambucana, o partido exercia maior controle na zona da Mata (região das usinas e dos engenhos), atingindo também as facções não dominantes do Agreste e do Sertão, que por questões locais, conflitavam com o PSD" (PANDOLFI, 1984, 106).

Nas disputas eleitorais entre o PSD e a UDN, este último só venceria o pleito governatorial em 1958, com Cid Sampaio. João Cleofas (UDN) chegaria a ocupar o cargo de Ministro da Justiça, no segundo governo Vargas (1951-54), em um dos poucos momentos onde o partido regional se alinhou a Getúlio, ignorando as determinações nacionais do partido. Em Pernambuco, a UDN era a segunda força nas bancadas do legislativo federal e estadual. Nesse contexto, pode-se afirmar que a UDN era a principal força a fazer frente à hegemonia pessedista (PANDOLFI, 1984, 107).

Embora fosse um dos três maiores partidos nacionais, em Pernambuco, o Partido Trabalhista Brasileiro (PTB) tinha pouca expressão e funcionou muitas vezes como "fiel da balança" entre PSD e UDN. A nível nacional, a principal força deste partido estava em suas bases sindicais. Em Pernambuco, o PSD, durante a interventoria de Agamenon, havia cooptado os sindicatos para suas fileiras. Sendo assim, aquela que seria a força do PTB, em Pernambuco, estava sob o controle do PSD. Na capital Recife, que poderia ser um reduto de forças para o PTB, por ser um 
local de maior concentração operária, eram os comunistas que tinham a predileção do eleitorado. Ao contrário do que ocoreu à nível nacional, onde a aliança PSD/PTB foi uma fórmula vitoriosa, ao menos no período do governo Kubitschek, em Pernambuco, os trabalhistas se alinhavam a UDN no combate ao PSD (PANDOLFI, 1984, 108).

O Partido Comunista Brasileiro (PCB) teve uma presença marcante, principalmente na capital do estado. Prova da sua força foi o fato de nas eleições presidenciais de 1945 o candidato comunista ledo Fiuza ter sido o vencedor na grande Recife. Na mesma ocasião, o partido elegeu três deputados federais (PANDOLFI, 1984, 108-9). Mesmo na ilegalidade, o Partido Comunista foi fundamental para a formação da Frente do Recife em 1955. Tratava-se de uma aliança político-partidária entre comunistas, socialistas e correntes de esquerda independentes, com base em um programa de cunho democrático e nacionalista. A primeira eleição na qual a Frente do Recife participou da disputa foi o pleito para prefeito do Recife. A capital havia acabado de receber autonomia para escolher seus governantes por meio de sufrágio eleitoral. Durante o Estado Novo, o prefeito da capital era nomeado pelo interventor estadual. O candidato da Frente do Recife, o socialista Pelópidas Silveira (PSB), foi eleito prefeito do Recife (PANDOLFI, 1984, 109; SOARES, 1982, 46).

Em 1957, a UDN se juntou à Frente do Recife formando a chapa Oposições Unidas. Além da UDN, os partidos que compunham a chapa eram o Partido Socialista Brasileiro (PSB), o Partido Trabalhista Nacional (PTN), o Partido Trabalhista Brasileiro (PTB) e o Partido Social Progressista (PSP), além dos comunistas. Pelo lado da UDN, houve resistência com relação ao apoio dos comunistas à chapa, e também com relação à escolha do nome de Cid Sampaio para disputar as eleições para o governo do estado, que ocorreriam em 1958. Alguns setores da UDN preferiam um nome mais moderado. É importante destacar que os prórios comunistas se opuseram a essa hipótese e exigiram a manutenção do nome de Cid Sampaio. Pelópidas Silveira se descompatiblizou da prefeitura do Recife para concorrer ao cargo de vice-governador pela chapa. Miguel Arraes, deputado estadual pelo PSD, foi o principal coordenador da campanha de Cid Sampaio. Antes do pleito, Arraes deixou o PSD e passou a integrar o Partido Social Trabalhista (PST) (SOARES, 1982, 46).

Ao contrário do que ocorria no nível nacional, onde a UDN era a principal inimiga da esquerda, em Pernambuco, ela contou com o apoio da esquerda contra o PSD. Esse é um dado importante das caracteristicas partidárias regionais no período, 
que em muitos casos se diferenciavam da posição dos diretórios nacionais. A partir do pleito presidencial de 1960, a UDN pernambucana passaria a se alinhar ao direcionamento proposto pelo diretório nacional do partido (SOARES, 1982, 75).

Eleito governador, Cid Sampaio afastou-se da Frente do Recife, embora o rompimento oficial da esquerda com o governo Cid Sampaio só tenha ocorrido em 1962. Em janeiro do referido ano, os comunistas, por meio de uma carta, afirmaram que Cid se distanciou das medidas defendidas durante a campanha, "passou a reprimir o movimento dos trabalhadores, estabeleceu um governo exclusivamente udenista, ligou-se ao imperialismo americano e procurou esvaziar a SUDENE", rompendo assim com o governador (SOARES, 1982, 78).

Esboçada as caracteristicas dos partidos políticos e das coligações formadas no estado de Pernambuco, no final dos anos 1950 e início dos anos 1960, busca-se, agora, caracterizar os dois principais atores políticos do estado. A próxima seção trata de Cid Sampaio e Miguel Arraes.

\section{5 - Cid Sampaio e Miguel Arraes: dois lados de uma mesma moeda.}

Após a derrubada da oligarquia pessedista, os movimentos sociais ganharam força, ao mesmo tempo em que nenhum partido foi capaz de dominar politicamente o estado. "Fora do poder, o pessedismo deixa seu papel de principal ator político". A partir de 1958, um novo quadro político se abre com a vitória da chapa Oposições Unidas. Quando o pessedismo foi "excluído do poder e esfacelado politicamente, todo o tradicional sistema partidário pernambucano se desagrega" (PANDOLFI, 1984, 199).

Nesse sentido, os governos Governo Cid Sampaio (1959-1962) e Miguel Arraes (1963-1964) representam tentativas de ocupar o espaço deixado pelo PSD e são extremamente importantes para a história política de Pernambuco. Cid Sampaio e Miguel Arraes são dois lados de uma mesma moeda, na medida em que ambos crescem politicamente no vácuo de poder deixado pelo fim da hegemonia pessedista no estado. Em um primeiro momento, os dois políticos se uniram contra o PSD, mas a partir da imprevisibilidade do cenário político estadual, sem o PSD no governo, os dois passaram a se opor (PANDOLFI, 1984, 199).

Miguel Arraes, no inicio de sua carreira política, foi Secretário da Fazenda do governo Barbosa Lima Sobrinho (PSD) e, em 1950, foi eleito deputado estadual pelo 
PSD, tendo se desligado do partido apenas em 1958, quando disputou as eleições pelo PST, coligado à Frente do Recife. Em 1958, foi um dos principais articuladores da campanha de seu cocunhado Cid Sampaio ao governo do estado. $\mathrm{Na}$ administração Sampaio, ele ocupou o cargo de Secretário da Fazenda até 1959, quando se desligou para concorrer à prefeitura do Recife, contando para isso com o apoio político de Cid Sampaio.

Usineiro, filho de senhores de engenho e com família de trajetória política relevante, Cid Sampaio tem um histórico mais antigo de oposição ao PSD. Os irmãos de Cid fizeram longa carreira política. Alde Sampaio foi deputado constituinte em 1934 e 1946. Lael Sampaio ocupou secretárias nos governos de Barbosa Lima Sobrinho (PSD) e Cid Sampaio (UDN). Os irmãos foram simpáticos à Revolução de 1930 e se opuseram ao Estado Novo. Os três participaram ativamente na criação da UDN e, em 1958, Cid e Alde foram eleitos pela UDN, em coligação na chapa Oposições Unidas, governador e deputado federal, respectivamente.

Para Joseph Page (1972, 74), Cid Sampaio não era o tipo de ator político capaz de liderar uma ruptura política com implicações transformadoras no estado. Ainda segundo esse autor, assim que foi o eleito, o governador buscou se afastar das correntes de esquerda que o apoiaram. No entanto, Dulce Pandolfi $(1984,200)$ destaca que Cid Sampaio buscou manter o equilíbrio entre seu governo e os grupos de esquerda. Prova disso teria sido a nomeação de uma assessoria sindical com líderes abertamente ligados ao Partido Comunista. Para a autora, "isso representava um apelo à continuidade da aliança, dentro dos marcos de controle do estado".

Ainda em 1959, Cid enfrentou duas questões importantes. A primeira delas, relacionada ao campo, dizia respeito à desapropriação do engenho Galileia para reforma agrária. Tal medida foi criticada pelos setores mais tradicionais do estado. A segunda, estava relacionada ao debate em torno da sucessão para a prefeitura do Recife. Segundo Pandolfi $(1984,200)$, a indicação de Arraes não agradava o governador pernambucano. Porém, Cid Sampaio reuniu cerca de quinhentos comerciantes e industriais para comunicar-Ihes que apoiava Arraes. É somente nas eleições presidenciais de 1960, que o distanciamento entre o governador Cid Sampaio e Miguel Arraes ganha evidência. No entanto, os dois só romperiam publicamente em 1962, no contexto da disputa pelo governo do estado.

Cid Sampaio buscou associar a imagem de seu governo ao desenvolvimento econômico. O governador lançou um programa de desenvolvimento econômico que 
incluía: melhoria rodoviária, reforma agrária e melhoria portuária. Ao final de 1960, ele havia criado o Distrito Industrial e 48 novas indústrias instalaram-se em Pernambuco. Ainda em 1960, especulava-se sobre uma possível candidatura de Cid ao palácio da Alvorada em 1965 (DIÁRIO de PERNAMBUCO, 15/07/1960, p. 18).

Desde o início de seu governo, Cid buscou recursos para colocar em prática seu projeto de industrialização estadual. O governador Cid Sampaio celebrou acordos com a administração Eisenhower através do programa Ponto IV. ${ }^{38}$ Pelo programa, criou-se uma escola de polícia e foi oferecido treinamento à polícia do estado. No ensino universitário de Pernambuco, foram trazidos professores e iniciados programas de auxílio tecnológico, além de diversos cursos, sob convênio do Centro de Produtividade, que oferecia treinamento a empresários (DIÁRIO de PERNAMBUCO, 14/01/1960, p. 16).

Cid Sampaio foi um crítico da autonomia da SUDENE, que em muitos momentos se contrapôs aos interesses da administração local. Em reunião do Conselho Deliberativo do órgão, chegou a afirmar que "se ela continuasse agindo paralelamente aos serviços estaduais, superando os governos, era preferível que o Congresso Nacional decretasse de uma vez intervenção no Nordeste" (PANDOLFI, 1984, 201).

Em 1962, ao romper com Cid Sampaio, a esquerda o acusou de ter se envolvido com o Instituto Brasileiro de Ação Democrática (IBAD) e com a Aliança para o Progresso, o que era fato incontestável. Além disso, o acusavam de apoiar o imperialismo contra os movimentos sociais e a SUDENE (PANDOLFI, 1984, 203). ${ }^{39} \mathrm{O}$ governo norte-americano, por sua vez, via em Cid Sampaio um de seus aliados mais fortes no Nordeste. Eles acreditavam que os comunistas, aproveitando o sofrimento econômico e a miséria humana na região, estavam trabalhando com rapidez e eficácia na subversão regional. O sucesso ou falha de Cid Sampaio em realizar seu programa

38 O Ponto IV estabelecia um conjunto de medidas estratégicas destinada a promoção do desenvolvimento industrial dos países subdesenvolvidos. Sua principal característica foi a aplicação de assistência técnica através da instituição de comissões onde foram elaborados estudos sobre a economia dos países participantes (BARROS, 2017, p. 40).

${ }^{39} \mathrm{O}$ Instituto de Pesquisa e Estudos Sociais (IPES) e o Instituto Brasileiro de Ação Democrática (IBAD) eram entidades civis de caráter anticomunista. Em 1962, as duas foram acusadas de receberem recursos do governo norte-americano, por intermédio da CIA, para financiar candidatos de direita, próEstados Unidos, durante as eleições de 1962. A denúncia foi feita por Miguel Arraes e uma CPI foi instaurada. Contudo, após o golpe civil-militar, a CPI foi interrompida (IBAD: INTERFERÊNCIA DO CAPITAL ESTRANGEIRO NAS ELEIÇÕES DO BRASIL, 2016, p. 231-39). 
de desenvolvimento era considerado crucial para a política externa norte-americana na América Latina. ${ }^{40}$

Na sucessão estadual de 1962, o PSD, marginalizado do poder, precisava se alinhar com outras agremiações para a disputa. No centro da chapa Oposições Unidas ocorreu uma polarização. João Cleofas foi indicado candidato pela UDN e Miguel Arraes pelo PST, este último com apoio da Frente do Recife. A candidatura de Arraes para o governo do estado cresceu ainda em 1961. José Ermínio de Moraes, industrial, candidato ao senado por Pernambuco, financiou a campanha de Arraes ao governo. Nessa época, Pernambuco vivia um clima de radicalização política, com reflexos no panorama nacional, que já se encontrava marcado pela polarização entre as forças da esquerda e as conservadoras (PANDOLFI, 1984, 204; COMISSÃO ESTADUAL DA VERDADE, 2016, 277).

O PSD se deparou com uma situação dificílima. Por um lado, uma aliança com a UDN era virtualmente impossível, dado o histórico de disputas entre os dois partidos. Por outro lado, a essa altura, a candidatura de Arraes já era bastante associada à esquerda e, portanto, criava uma série de desconfortos no seio do PSD. No inicio, o PSD tentou articular a candidatura de Barbosa Lima Sobrinho, mas diante da falta de consenso entre seus correligionários, liberou o posicionamento de seus políticos. Mesmo assim, o PSD acabou lançando o nome de Paulo Guerra a vicegovernador na chapa de Arraes. Cabe destacar que Arraes iniciou sua carreira no PSD e participou do governo de Barbosa Lima Sobrinho. Este, inclusive, não teve sua candidatura efetivada, pois poderia desgastar a candidatura de Arraes, pela ligação próxima entre os dois. Nesse sentido, infere-se que Arraes era mais "alinhado" ao PSD do que Cleofas da UDN. Por fim, a cúpula do PSD se dividiu em três posições: o grupo liderado por "Etelvino Lins apoia João Cleofas. Outro setor, liderado por Paulo Guerra, apoia Miguel Arraes. [...] um terceiro grupo endossa a candidatura de Armando Monteiro Filho" (PANDOLFI, 1984, 204).

A polarização eleitoral entre Comunismo e Democracia partiu da própria UDN e contou com o apoio do Diário de Pernambuco. Num primeiro momento o jornal defendeu a união da UDN e PSD em torno da candidatura de João Cleofas. Mas essa tese obteve pouca receptividade, dado o histórico de oposição entre os dois partidos (PANDOLFI, 1984, 204). O único momento em que essa coligação se fez possível foi

${ }^{40}$ Report, ARA/EST/B, 457-b - 722-a, "Financial Assistance to State of Pernambuco", December 14, 1960, Box 9, RG 56, NARA. 
após a morte de Agamenon Magalhães, e ocorreu em torno da candidatura de Etelvino Lins. A Aliança para o Progresso, em diversos momentos, foi utilizada para alimentar essa polarização.

O governo dos Estados Unidos contribuiu para alimentar essa polarização. possível sucesso de Miguel Arraes em Pernambuco e a renúncia de Jânio Quadros levaram os Estados Unidos a realizar acordos diretamente com o governador Cid Sampaio, ultrapassando a autoridade da SUDENE. Os Estados Unidos acreditavam que Pernambuco poderia ser um símbolo de sucesso da Aliança no Nordeste se os projetos da USAID pudessem ser implementados em tempo.

Nesse contexto de polarização política, estimulada pela Guerra Fria, e de interferência norte-americana em Pernambuco, o próximo capítulo se debruça sobre a análise do conteúdo publicado pelo jornal Diário de Pernambuco a respeito da Aliança para o Progresso e sua relação com os principais acontecimentos políticos do estado. Busca-se entender as possíveis relações entre a narrativa publicada pelo jornal e estes acontecimentos políticos, em especial, a polarização política nas eleições de 1962 para o governo estadual. Busca-se entender estas relações levandose em consideração os acontecimentos políticos no âmbito federal. 


\section{Capítulo 02: A Aliança para o Progresso narrada através do Diário de Pernambuco.}

Este capítulo analisa editoriais, colunas e o tratamento dado a notícias referentes à Aliança para o Progresso publicados pelo jornal Diário de Pernambuco, em cruzamento com documentos oficiais do governo norte-americano. Conclui-se que - Diário de Pernambuco defendeu a Aliança para o Progresso e os acordos diretos entre governadores estaduais brasileiros e os Estados Unidos. Afirma-se também que durante a fase de aproximação entre o Presidente Goulart e os Estados Unidos, notadamente durante a visita de Goulart à Washington, em abril de 1962, o Diário de Pernambuco buscou retratar a Aliança como um esforço de cooperação entre os dois governos; porém, à medida que as relações entre os dois governos foram se desgastando, a Aliança foi usada pelo jornal para criticar o Presidente João Goulart e o governador Miguel Arraes, em consonância com as posições do consulado norteamericano no Recife e da embaixada no Rio de Janeiro.

\section{1 - O Progresso da Aliança narrado através das publicações do Diário de Pernambuco.}

Esta seção tem como objetivo analisar o conteúdo relativo ao programa de ajuda norte-americano Aliança para o Progresso a partir das publicações do jornal Diário de Pernambuco. A fim de atingir este objetivo, foram analisados os editoriais, as colunas assinadas pelos seus principais colaboradores e, por fim, o tratamento dado às notícias relativas a Aliança para o Progresso. Busca-se entender as possíveis relações entre o conteúdo publicado sobre a Aliança pelo jornal e os principais acontecimentos políticos sobre o estado de Pernambuco e ao governo federal no período.

Fundado ainda nos tempos do Império, em 7 de novembro de 1825, o Diário de Pernambuco é o jornal mais antigo em circulação na América Latina. Durante a maior parte da primeira República, o jornal assumiu a posição de órgão oficial do governo pernambucano, publicando atos de governo, notas fúnebres e anúncios oficiais. Em 
1931, foi comprado pelo grupo Diários Associados, pertencente a Assis Chateaubriand. O jornal foi crítico dos rumos da Revolução de 1930 e demonstrou simpatia pela Revolução Constitucionalista de 1932. ${ }^{41}$

Durante o período do Estado Novo, o jornal reduziu o noticiário político a publicação de atos oficiais e discursos laudatórios de autoridades. Em 1945, combateu o Queremismo, um movimento político que pretendia criar condições para a permanência de Getúlio Vargas no poder após 1945 e cujo slogan era "Queremos Getúlio". No mesmo ano o periódico foi fechado, tendo seu redator-chefe, Aníbal Fernandes, preso. Isso ocorreu quando estudantes da Faculdade de Direito do Recife, em nota publicada no Diário de Pernambuco, convocaram um ato público em apoio à candidatura do Brigadeiro Eduardo Gomes (UDN) à presidência da República. A manifestação terminou em um confronto na praça do Diário de Pernambuco. Vários oposicionistas foram feridos e o estudante Demócrito de Souza Filho e o carvoeiro Manuel Elias foram mortos. O Diário de Pernambuco teve sua circulação proibida por 35 dias. Gilberto Freyre e Aníbal Fernandes foram presos. A Secretária de Segurança Pública emitiu a seguinte nota oficial (PANDOLFI, 1984, p. 92-94):

O povo pernambucano está suficientemente inteirado da atitude que o Diário de Pernambuco vem assumindo da mais franca agitação subversiva. Insuflando por todos os meios a discórdia social, explorando a classe universitária, na qual vem fomentando incoercíveis paixões políticas, o Diário de Pernambuco é responsável por um período de preparação e agitação política que culminou, recentemente com fatos deploráveis [...] Ultimamente o jornal tomou a mais insólita atitude contra o Presidente Getúlio Vargas, publicando em manchete que o chefe do governo nacional deveria ser deposto (SECRETÁRIA DE SEGUNRANÇA PÚBLICA, apud PANDOLFI, 1984, p. 92-3).

Os protestos contra o governo repercutiram em todo o país, contando com atos no Rio de Janeiro, com a participação de Carlos Lacerda e muitos outros políticos. Nesse contexto, o Diário de Pernambuco passou a ser o porta voz da oposição aos governos de Agamenon Magalhães, Etelvino Lins e Getúlio Vargas, incluindo-se também a oposição ao PSD (PANDOLFI, 1984, 94).

41 Dicionário Histórico-Biográfico Brasileiro, CPDOC, verbete Diário de Pernambuco, http://www.fgv.br/cpdoc/acervo/dicionarios/verbete-tematico/diario-de-pernambuco Acesso em: 18/03/2017. 
Em 1952, após a morte de Agamenon, o jornal apoiou o governo de Etelvino Lins (PSD), eleito governador em coligação com a UDN, em um dos poucos momentos da história de Pernambuco onde UDN e PSD estiveram do mesmo lado. Em 1954, nas eleições para o governo do estado, apoiou o candidato derrotado João Cleofas (UDN). O jornal então passou a fazer oposição ao governo de Cordeiro Farias (PSD). Em 1958, deu suporte à chapa Oposições Unidas, que lançou a candidatura de Cid Sampaio (UDN). Defendeu a chapa de Cid Sampaio mesmo quando esta lançou Miguel Arraes como candidato à prefeitura do Recife, mas passou a criticar Arraes quando o então prefeito se aproximou de setores da esquerda. $O$ jornal manteve 0 suporte a Cid Sampaio durante todo seu governo. Na esfera federal, apesar de ter apoiado a candidatura de Juarez Távora (UDN), não se opôs ao governo Juscelino Kubitscheck (PSD). Em 1960, abraçou a candidatura de Jânio Quadros (UDN) à presidência da República ${ }^{42}$.

Nos anos 1960, o jornal era líder do Nordeste e do Norte brasileiro (NASCIMENTO, 1963, 179). O jornalista baiano José Andrade de Almeida Castro era o diretor do jornal no período, o qual contava com uma longa lista de colaboradores, dentre os quais se destacam Murilo Marroquim, senhor de engenho e jornalista do grupo Diários Associados. Foi correspondente em Londres, durante a $2^{\mathrm{a}}$ Guerra Mundial e, durante a ditadura militar, escreveu uma série de artigos contra Don Helder Câmara, em apoio aos militares; Eugênio Gudin, economista de orientação liberal, adepto do monetarismo ortodoxo, foi Ministro da Fazenda durante o governo do Presidente Café Filho. Nos anos 1960, escreveu uma série de artigos para a imprensa defendendo a deposição do Presidente Goulart; Gilberto Freyre, escritor, ensaísta e sociólogo, iniciou a carreira no jornal Diário de Pernambuco e manteve-se ocasionalmente contribuindo com artigos. O intelectual apoiou o golpe militar de 1964; e Assis Chateaubriand, jornalista e magnata do ramo das comunicações, era o proprietário do grupo Diários Associados. Teve uma relação conturbada com Getúlio Vargas, assumindo por fim uma posição antigetulista que se manifestou nos seus jornais. Essa posição manteve-se durante o governo de João Goulart.

Durante os dias da semana, as edições traziam dois cadernos, geralmente contendo entre 16 e 18 páginas. A edição de domingo possuía quatro cadernos e circulava com mais de 40 páginas. O primeiro caderno da edição semanal trazia na 
capa a notícia principal na parte superior, centralizada, acompanhada de uma imagem. A segunda página trazia as notícias internacionais e uma coluna assinada por Aníbal Fernandes chamada "Momento Internacional”. A terceira página trazia o noticiário nacional. A quarta trazia dois editoriais e as colunas com artigos de opinião dos principais colaboradores do jornal. Ao alto, com título em quatro colunas aparecia o artigo de Assis Chateaubriand. A página cinco continha as notícias da região e a coluna "Ontem, no Palácio”, relacionada aos atos do governador. A sexta página trazia duas colunas, "Vida Escolar" e "Diário Social". A sétima página era dedicada à seção policial e as páginas oito e nove traziam as conclusões de outras seções. As páginas dez e onze dedicavam-se ao noticiário esportivo. O caderno dois trazia basicamente anúncios, tirinhas, colunas de artes e cinema, e também notícias relacionadas a cidades da região e outros estados, como era o caso de "de Olinda" e "Rio Grande do Norte". A última página trazia colunas intituladas "Periscópio", "Câmara Municipal" e "Na assembleia Legislativa" com notícias relacionadas ao legislativo estadual e municipal.

O termo Aliança para o Progresso apareceu pela primeira vez no Diário de Pernambuco em 19 de outubro de 1960. Sob o título de "Kennedy: Estados Unidos sofrerão derrotas desastrosas na América Latina", o jornal reproduziu trechos do discurso do candidato Democrata à presidência dos Estados Unidos. Nele, Kennedy responsabilizou seu adversário Richard Nixon pelo fracasso da política externa dos Estados Unidos para a América Latina e apresentou aquela que seria sua nova política para o continente - uma Aliança para o Progresso. Segundo Kennedy, "Uma aliança de nações com o interesse comum na liberdade e no progresso econômico". Ele ainda afirmou que o tempo de "salvar Cuba" havia passado e que era a hora dos Estados Unidos reconquistarem a amizade do povo cubano e resistir ao Comunismo. Embora o jornal não tenho comentado o discurso do candidato, a matéria teve destaque na página 2 (dedicada ao noticiário internacional) (DIÁRIO DE PERNAMBUCO, 19 de outubro de 1960, p. 02). Nos dias seguintes, os colunistas do Diário nada publicaram a respeito do discurso de Kennedy ou sobre a Aliança. O destaque das colunas foi dado a sucessão presidencial no Brasil.

A Aliança para o Progresso voltou a aparecer nas páginas do Diário em 14 março de 1961, em decorrência do lançamento do programa em discurso do presidente Kennedy para o Corpo Diplomático Latino-Americano na Casa Branca. A referida matéria apareceu na parte inferior da capa, ao lado da manchete "Julião 
importa Fidel Castro", sob o título "Kennedy: substancial ajuda à América Latina". Desde então, a Aliança apareceu quase que diariamente nas páginas do Diário durante o ano de 1961, e foi tratada sistematicamente como a "Aliança do Presidente Kennedy", o que transmitia a ideia de que a Aliança era uma iniciativa apenas dos Estados Unidos, sem qualquer ativismo da América Latina (DIÁRIO DE PERNAMBUCO, 14 de março de 1961, p. 01). Essa abordagem do jornal ficou menos evidente a partir de 1962, provavelmente porque Kennedy dependia da aprovação orçamentária do Congresso para financiar a Aliança e porque alguns políticos latinoamericanos assinaram acordos com a Aliança. Especificamente, durante a viagem de Goulart aos Estados Unidos, em abril de 1962, o Diário de Pernambuco buscou associar a Aliança à Operação Pan-americana (OPA). ${ }^{43}$ Esse é um exemplo de que a abordagem do jornal com relação a Aliança podia mudar de acordo com o momento político.

Em agosto de 1961, os ministros da fazenda da Organização dos Estados Americanos (OEA) se reuniram em Punta del Este, no Uruguai, paro o lançamento da Aliança para o Progresso. "A conferência foi o ponto alto da política latino-americana de Kennedy". Na ocasião, foi assinada a Carta de Punta del Este, por todos os países membros da OEA, exceto Cuba (WEIS, 2001, p. 331). O Diário de Pernambuco publicou editoriais exaltando os Estados Unidos e sua disposição para ajudar o desenvolvimento econômico da América Latina. O primeiro deles é de 11 de agosto de 1961, com o título de "Desenvolvimento e Democracia":

Quem quer que acompanhe o noticiário dos debates e estudos da
Conferência de Punta Del Este chega à conclusão de que a América Latina
está realmente compenetrada de que é chegado o momento histórico de
marchar ao encontro dos seus grandes destinos. E esses grandes destinos
não se confundem com as promessas daqueles que, através de formulas
ideológicas, procuram subverter o tradicional espírito de solidariedade do
hemisfério e aniquilar o que de mais caro existe na condição de pessoa
humana. Há da parte dos países americanos uma vontade irrefreável de fazer
progredir a economia latino-americana dentro do sistema democrático,
aproveitando-se os estímulos oferecidos pelo programa da Aliança para o
Progresso para eliminar a miséria, a fome, o analfabetismo e os baixos

\footnotetext{
${ }^{43}$ Esse tema específico será tratado mais adiante nesse capítulo.
} 
índices sanitários de todas as repúblicas da América (DIÁRIO DE PERNAMBUCO. Desenvolvimento e Democracia. 11/10/1961, p. 04)

Nota-se, por meio desse editorial, que a Aliança para o Progresso seria um programa capaz de fazer progredir a economia latino-americana, e que esse seria o desejo das nações da região. As linhas da publicação falam sobre "fórmulas ideológicas que procuram subverter o tradicional espírito de solidariedade" - trata-se, evidentemente, do comunismo. A Aliança seria uma forma de fazer progredir a economia latino-americana e evitar a ameaça comunista. Subentende-se que se trata de um mecanismo de defesa do hemisfério, no contexto da Guerra Fria no Terceiro Mundo. A temática da Guerra Fria na América Latina vai ser abordada em diversos outros momentos, de modo mais explícito, a ponto de o jornal identificar políticos da região como uma ameaça de subversão comunista no Nordeste.

O editorial, de 18 de agosto de 1961, intitulado "Novos Rumos à América Latina", por exemplo, segue a mesma linha favorável aos Estados Unidos e à Aliança para o Progresso:

Agora com o sucesso da Conferência de Montevideo os países da América Latina têm aberto, diante de si, o caminho do desenvolvimento: a trilha capaz de conduzi-los à solução de todos os problemas que afligem suas comunidades, que impedem seu povo de alcançar níveis de vida compatíveis com esta época de tanto progresso técnico e econômico. A Ata de Punta Del Este, firmada ontem, representa, por isso, o documento mais importante já surgido nas relações continentais e assinala, realmente, o começo de uma nova era na história das Américas.

Uma nova era no sistema de colaboração dos Estados Unidos com as chamadas nações abaixo do Rio Grande. Nova era de um esforço total das Américas do Norte, Centro e Sul, para proporcionar a todos os povos latinoamericanos meios de superar desníveis que os separam das nações mais evoluídas. Era nova preparada quase sobre os escombros do velho panamericanismo, cuja preocupação fundamental era o de preservar uma boa vizinhança apenas à base de princípios políticos [...] (DIÁRIO DE PERNAMBUCO. Novos Rumos à América Latina, 18/10/1961, p. 04.)

Os editoriais revelam que, no ano de 1961, a Aliança foi tratada como um novo fenômeno nas relações entre Estados Unidos e a América Latina, capaz de conduzir 
as nações do continente por um caminho de progresso solucionando "todos" os seus problemas. Não há sequer uma crítica aos Estados Unidos. Por outro lado, o editorial critica o que chama de "velho pan-americanismo", acusando-o de preocupar-se apenas em "preservar uma boa vizinhança" com base em "princípios políticos". Enquanto isso, a Aliança seria o esforço conjunto das nações da América do Norte, Central e do Sul capaz de superar os problemas econômicos. Nesse sentido, o jornal dá a entender que a Aliança para o Progresso é um novo e efetivo "panamericanismo". Percebe-se aí uma clara preferência do jornal pelas relações interamericanas sob a tutela dos Estados Unidos.

Em 25 de agosto de 1961, Jânio Quadros repentinamente renunciou ao cargo de presidente. Quadros perdeu apoio da UDN, partido conservador que lançara sua candidatura. Sua política de austeridade econômica interna e de independência nos assuntos externos - a chamada Política Externa Independente (PEI) - acabou por ofender seus aliados e despertou desconfiança em seus opositores (WEIS, 2001, 332). É provável que Quadros estivesse manobrando "para diminuir a legitimidade política do Congresso diante da opinião pública" (LOUREIRO, 2009, 187). Ele contava com o descontentamento dos militares com relação ao Vice-Presidente João Goulart, do Partido Trabalhista Brasileiro (PTB) e com a possível recusa do Congresso Nacional em aceitar sua renúncia, o que acabou não ocorrendo. Loureiro (2009, 2045) destaca que a tese de que Quadros esperava o apoio do Congresso para voltar ao governo com poderes ampliados não condiz com as tentativas anteriores do presidente de tentar esvaziar os poderes do Legislativo. Em 7 de setembro de 1961, - Presidente João Goulart tomou posse com poderes reduzidos. O impasse institucional foi resolvido com a adoção do sistema parlamentarista de governo (WEIS, 2001, p. 332). Apesar de o Presidente Goulart desagradar os oficiais norteamericanos, por suas heranças varguistas e ligações com a esquerda trabalhista, de acordo com Michael Weis (2001, 332-3), o governo americano optou por não interferir na crise de sucessão institucional brasileira. Loureiro destaca o contrário. Segundo o autor, o Presidente Kennedy estava disposto "a ajudar secretamente os militares brasileiros com comida e armas, se a situação se tornasse 'séria'”. Para o autor, esta atitude diante da crise brasileira demonstrava que "o compromisso de Washington com a democracia na América Latina era limitado" (LOUREIRO, 2014, p. 333).

O ano de 1962 foi fundamental para o desenvolvimento das ações norteamericanas através da Aliança para o Progresso no Nordeste. Ainda em dezembro de 
1961, a declaração feita por Fidel Castro de que era marxista-leninista aumentou as preocupações da administração Kennedy com a América Latina. A segunda conferência de Punta Del Leste, em janeiro de 1962, foi uma oportunidade para colocar o governo Goulart à prova no tocante à sua posição em relação aos interesses americanos para o hemisfério. Os Estados Unidos pretendiam que os membros da OEA também rompessem relações e impusessem sanções à Cuba. O governo brasileiro se posicionou contra as sanções baseando-se no princípio da nãointervenção e ressaltou que o isolamento de Cuba a deixaria totalmente à mercê da União Soviética. Outros países importantes como Argentina, México, Chile, Equador e Bolívia apoiaram a posição do Brasil. Contudo, os Estados Unidos conseguiram os votos mínimos necessários para expulsar Cuba da OEA e da Junta Interamericana de Defesa, suspender a venda de armas para o país, além de obter a declaração da incompatibilidade do comunismo com os princípios liberais e democráticos do hemisfério. Ainda que Cuba tenha sido expulsa da OEA, a neutralidade de países importantes, como o Brasil, reduziu a legitimidade da ação perante a opinião pública hemisférica (WEIS, 200, 333-36; BANDEIRA, 1977, 47).

Outro fator de desgaste nas relações entre os Estados Unidos e o Presidente João Goulart foi a encampação das empresas norte-americanas, International Telephone \& Telegraph (ITT) e American \& Foreign Power (AMFORP), pelo governador do Rio Grande do Sul, Leonel Brizola, e a aprovação pela Câmara dos Deputados, em novembro de 1961, de uma lei de restrição da remessa de lucros de empresas privadas ao exterior. O projeto Celso Brandt estabeleceu severas restrições a atuação do capital externo no Brasil (LOUREIRO, 2017, 209). ${ }^{44}$ Tais fatores despertaram a oposição de empresários norte-americanos. Estes últimos, para defender seus interesses no Brasil, pressionaram o governo Kennedy para suspender a ajuda financeira a países que desapropriassem empresas norte-americanas sem a imediata e justa indenização. Como resultado dessa pressão foi aprovada a emenda Hickenlooper. A emenda Hickenlooper determinava a suspensão de qualquer ajuda

\footnotetext{
${ }^{44} \mathrm{Em}$ decorrência da aprovação dessa lei, ainda que não exclusivamente devido a ela, foi criado o Instituto de Pesquisas e Estudos Sociais. Esse grupo recebeu investimentos de empresários estrangeiros e teve um papel crucial na militância contra medidas nacionalistas, além da já bem conhecida participação na campanha eleitoral de 1962 e na desestabilização do governo Goulart em apoio ao Golpe de 1964. Sobre as relações entre a aprovação do projeto Celso Brant e o IPES ver: Felipe Pereira Loureiro, Empresários, trabalhadores e grupos de interesse: A política econômica nos governos Jânio Quadros e João Goulart, 1961-1964 (São Paulo: Editora Unesp, 2017), capítulo 05.
} 
financeira a países que desapropriassem bens norte-americanos sem indenização imediata, adequada e efetiva (LEACOCK, 1999, 85-94; BANDEIRA, 1977, 49-63). ${ }^{45}$

Durante o período parlamentarista (setembro de 1961 - janeiro de 1963), o Brasil atravessou uma grave crise econômica, especialmente em razão do desequilíbrio de sua balança de pagamentos. Como parte da solução desse problema, o governo brasileiro dependia de empréstimos norte-americanos para honrar seus compromissos econômicos e para manter o nível de atividade da economia. Entre a segunda metade de 1961 e o primeiro semestre de 1962, o gabinete de Tancredo Neves (setembro de 1961 - julho de 1962) tentou colocar em prática dois planos de estabilização econômica, o Plano de Emergência e o Plano de Economia. Ambos acabaram fracassando devido a pressões de grupos sociais internos contrários às medidas de austeridade, como contenção do crédito e dos salários. A dificuldade de obtenção dos empréstimos junto ao governo norte-americano também foi crucial, pois sem os recursos do empréstimo o Brasil ficou vulnerável às ações de especuladores contra a moeda nacional, o que provocou sua desvalorização e o agravamento da crise (LOUREIRO, 2017, 239-42). ${ }^{46}$

Os acontecimentos políticos e econômicos, tratados acima, refletiram no conteúdo publicado pelo Diário de Pernambuco. A partir do fim de janeiro de 1962, o jornal passou a usar a Aliança para o Progresso para atacar a política externa do Presidente Goulart. A Aliança para o Progresso foi por diversas vezes tema das colunas de opinião da quarta página do primeiro caderno - a mesma dedicada aos editoriais do jornal.

Todas as colunas retrataram a Aliança para o Progresso e os Estados Unidos de forma extremamente positiva. Assis Chateaubriand foi quem mais se referiu à Aliança, na maior parte dos casos para criticar a Política Externa Independente do Presidente João Goulart, a quem acusava de tentar sabotar o programa econômico norte-americano. Chateaubriand também criticou San Thiago Dantas (PTB) enquanto Ministro das Relações Exteriores, referindo-se a ele como "gorila feroz e lúbrico". Celso Furtado e os funcionários da SUDENE foram chamados de "palhaços da

\footnotetext{
45 Para mais sobre as relações entre a Aliança para o Progresso e o empresariado norte-americano ver: Ruth Leacock, Requiem for Revolution: The United States and Brazil, 1961-1969 (Kent and London: Kent State University Press, 1990), capítulo 04.

${ }^{46}$ Sobre as condições impostas pelos Estados Unidos durante as negociações de financiamento com o governo Goulart ver: Felipe Loureiro, "The Alliance For or Against Progress? US-Brazilian Financial Relations in the Early 1960s", Journal of Latin American Studies, 46 (02), (2014), p. 323- 51.
} 
SUDENE" e "comuno-socialistas". Chama a atenção a retórica da Guerra Fria utilizada para criticar políticos brasileiros nacionalistas, como é o caso da expressão "comunosocialistas" utilizada por Chateaubriand para se referir a Celso Furtado e aos funcionários da SUDENE. É muito significativo que as críticas de Assis Chateaubriand fossem tão ferozes, uma vez que se tratava do proprietário do Diário de Pernambuco.

Os demais colunistas, de um modo geral, usaram suas colunas para criticar a Política Externa Independente e, principalmente, a posição brasileira com relação à Cuba. Como por exemplo em "Esvazia-se o Castrismo do Itamaraty", de Theophilo de Andrade, afirma-se que a posição do Brasil com relação à Cuba estava errada e que a "cada dia que passa os independentes se reduzem e o Brasil vai ficando só". $\mathrm{Na}$ verdade, o Brasil não estava só em seu posicionamento - o país liderava um grupo formado por Argentina, México, Equador, Chile e Bolívia (LOUREIRO, GOMES, BRAGA, 2018, 5). Para o colunista o Brasil estava quebrando a harmonia no continente " $\mathrm{a}(\mathrm{O})$ criar dificuldades para a própria Aliança para o Progresso" ao manter o apoio à Cuba, com destaque à liderança do Brasil no que foi chamado de "quebra da unidade continental" na Conferência de Punta del Este em janeiro de 1962. Outro tema corriqueiro era o de que, no caso do fracasso da Aliança, a culpa seria "nossa", como ocorre na coluna "Aliança para o Progresso", de Adelmar da Costa Carvalho e em outra de Geraldo Banas, onde ele afirma que "As nações latino-americanas têm a responsabilidade no possível fracasso da Aliança Para o Progresso" (DIÁRIO DE PERNAMBUCO, 06 e 07/04/1962, p. 04; 12/05/1962, p. 04).

As únicas colunas que fugiram à regra - no sentido de usar a Aliança para criticar o Presidente Goulart - foram escritas por Murilo Marroquim e publicadas entre 17 e 20 de abril de 1962. Em abril do mesmo ano, o Presidente Goulart visitou Washington e prometeu total comprometimento com um plano de estabilização econômica e também solucionar o problema das subsidiárias norte-americanas ITT e AMFORP. Havia a expectativa de que o encontro pudesse influenciar a posição política de Goulart, afastando-o da esquerda e dos movimentos sociais que sustentavam seu governo (LOUREIRO, 2014, p. 338). A capa do Diário de Pernambuco, de 15 de abril, refletiu essa expectativa. A manchete principal foi "Tese da união nacional em torno de Jango recebe ampla receptividade" (DIÁRIO DE PERNAMBUCO, 15/04/1962, p. 01). Enquanto isso, o Nordeste ganhava destaque como grande problema nacional, com manchetes como: "Nordeste é foco de desagregação nacional, afirma jornalista ianque" e "Revolução Comunista em marcha 
no Nordeste", ambas publicadas na capa do Diário (DIÁRIO DE PERNAMBUCO, 15 e 18/04/ 1962, p. 01 e 01).

Durante a visita de Jango aos Estados Unidos, ainda foi assinado, como já mencionamos, o "Acordo do Nordeste", resultado dos estudos elaborados por Celso Furtado e pelas recomendações do Relatório Bohan, no qual os Estados Unidos se comprometeram a investir US\$ 131 milhões (US\$ 831 milhões em valores atualizados pelo Indíce de Preços ao Consumidor dos Estados Unidos) na região em dois anos (DIÁRIO DE PERNAMBUCO, 14/04/1962, p. 01). A assinatura do acordo também ganhou destaque com manchetes como "John Kennedy a Jango: mudaremos a face do Nordeste brasileiro" e "EE.UU ajudarão Nordeste a forjar seu desenvolvimento". Esta última reportagem apresentou trechos de uma entrevista com o Cônsul Delgado Árias, personagem importante para os desenvolvimentos das ações norte-americanas em Pernambuco (DIÁRIO DE PERNAMBUCO, 14/041962, p. 01 e 05).

Também foram publicados artigos de opinião favoráveis a Aliança e sua ação no Nordeste. Estes artigos destacaram o papel da Aliança na contenção do comunismo. Nota-se ainda, por meio destes artigos que o jornal tratou 0 desenvolvimento do Nordeste como uma questão fundamental para o combate do comunismo, em acordo com os objetivos norte-americanos. A Operação Panamericana foi pouco citada como influência para a Aliança (DIÁRIO DE PERNAMBUCO, 20, 26 e 27/1962, p. 04, 04 e 04).

Remontar as origens da Aliança à Operação Pan-americana (OPA) não foi algo comum no jornal, e mesmo entre os estudiosos da Aliança. Grande parte dos trabalhos sobre a Aliança interpretam seu lançamento como um triunfo da política externa dos EUA e especialmente do governo Kennedy, "comprando apoio latino-americano na luta contra o comunismo na esteira da revolução cubana" (DARNTON, 2012, 57). No entanto, para Christopher Darnton (2012, 57-8), a proposta original para a Aliança veio do Presidente Juscelino Kubitschek, formulador da Operação Pan-America (OPA) em 1958, um ano antes da vitória de Fidel Castro em Cuba. Este autor defende que a OPA teve um grande impacto na política externa dos EUA e na cooperação hemisférica. É provável que o clima da visita de Jango tenha motivado o jornal a buscar retratar a Aliança mais como uma cooperação entre os dois países do que uma iniciativa norte-americana.

Em 16 de agosto de 1962, toda a ajuda econômica acordada com o governo federal foi suspensa. Goulart manobrava para aprovar o presidencialismo e obter 
plenos poderes presidenciais. Está atitude certamente preocupava os Estados Unidos. Para continuar recebendo a ajuda econômica norte-americana o governo brasileiro deveria:

implementar um rigoroso programa de estabilização; resolver a desapropriação envolvendo empresas subsidiárias das empresas International Telephone and Telegraph (ITT) e American Foreign Power (AMFORP); terminar a política externa independente; e, mais importante, deixar de minar a 'democracia representativa liberal internamente' (isto é, Goulart seria forçado a romper laços com os comunistas no movimento trabalhista e a deixar de admitir esquerdistas em posições governamentais (LOUREIRO, 2014, 339).

Nesse contexto, em 1962, os editoriais do Diário de Pernambuco passaram a refletir os ataques ao Presidente João Goulart. O editorial "Razões de Desconfiança" defendeu a posição do Senado norte-americano de desconfiança quanto a Goulart, argumentando que essa era também a opinião dos brasileiros sensatos. Apesar disso, o editorial defendeu a manutenção da ajuda econômica através da Aliança, além de exaltar a disposição de ajudar do governo norte-americano, como pode ser observado no trecho destacado abaixo:

Em seu editorial, [...], o grande matutino de Nova York, refere-se a fraqueza da posição do presidente João Goulart e a ineficiência do Congresso para agir com seriedade e rapidez, no sentido de aparelhar o Brasil das leis indispensáveis as profundas reformas que, aqui como lá fora, são reclamadas com urgência. [...].

Os receios do New York Times são amplamente partilhados pela opinião sensata do Brasil. Apenas achamos que as nossas dificuldades e os perigos a que estamos sujeitos não se tornarão menores se, em vez de ajuda, encontrarmos da parte de nossos amigos americanos apenas recriminações que, embora parcialmente justificadas, não têm forças para mudar a natureza dos graves problemas que teremos de resolver (DIÁRIO DE PERNAMBUCO. Razões de Desconfiança. 03/03/1962, p. 04)

É importante destacar que apesar de concordarem com a posição de desconfiança em relação ao Presidente João Goulart, o editorial defende a 
manutenção da ajuda financeira ao país. Nos meses seguintes à publicação do editorial, os Estados Unidos intensificariam negociações de acordos da Aliança diretamente com os estados brasileiros, através das ilhas de sanidade. Segundo Loureiro, as ilhas de sanidade administrativa tinham 3 propósitos específicos:

[...] primeiro, restringir as alternativas políticas do governo federal por meio do fortalecimento de grupos políticos "democráticos", obrigando a União dialogar com os mesmos e assumir compromissos políticos, o que tenderia a moderar potenciais ações radicais por parte de Brasília; segundo, viabilizar a candidatura de lideranças que fossem "amigáveis" a Washington para o pleito presidencial de outubro de 1965; e, em terceiro, estabelecer uma espécie de "caução" (hedge) contra possíveis ações antidemocráticas de Jango ou de elementos da extrema esquerda, garantindo que estados-chave da federação brasileira estivessem em mãos "democráticas" (LOUREIRO, 2017, 149).

Loureiro ainda destaca que essa política teve um papel "ofensivo" fundamental para o golpe civil-militar de 1964, já que esses estados beneficiados pela política das ilhas de sanidade "mostraram-se essenciais para o processo de preparação e desencadeamento do golpe militar" (LOUREIRO, 2017, 149).

Movemos agora nossa lupa de investigação para o conteúdo do jornal e suas relações com a política local. Antes, porém, é necessário entender como o governo norte-americano vinha interpretando a política local de Pernambuco. No plano estadual, desde 1961, o consulado norte-americano, em Pernambuco, mostrou-se preocupado com a candidatura de Miguel Arraes para governador do estado. $O$ governo norte-americano via em Cid Sampaio um de seus aliados mais fortes no Nordeste. Acreditava-se que os comunistas, aproveitando o sofrimento econômico e a miséria humana na região, estavam trabalhando com rapidez e eficácia na subversão regional. Os Estados Unidos acreditavam que Pernambuco poderia ser um símbolo de um sucesso dramático da Aliança no Nordeste se os projetos da USAID pudessem ser implementados a tempo (ROETT, 1972, 92).

Kennedy, pessoalmente, estava preocupado com o andamento dos projetos da Aliança no Nordeste e com as eleições para o Congresso Nacional e governadores dos estados no Brasil, que ocorreriam em outubro de 1962. O interesse de Kennedy no andamento da Aliança, baseado em suas preocupações com as eleições no Brasil, 
sugerem que ele relacionava o impacto politico da Aliança a possíveis resultados favoráveis em tais eleições. ${ }^{47}$

Nesse sentido, os Estados Unidos assinaram um acordo de educação com o estado de Pernambuco. No dia 05 de junho de 1962, foi assinado o Pernambuco Aliance for Progress Elementary and Basic Education. Na época, o então governador Cid Sampaio celebrou contratos compreendendo as seguintes áreas: educação, saúde, habitação popular e colonização (BARROS, 2017, 107). Ainda em 24 de setembro de 1962, às vésperas do pleito para governador, foi feito um empréstimo à Companhia Pernambucana de Borracha (COPERBO), coração do projeto industrial de Cid Sampaio, no valor de US\$3,4 milhões, na tentativa de influenciar positivamente a imagem de seu sucessor João Cleofas, da UDN (ROETT, 1972, 140).

O Diário de Pernambuco saiu em defesa dos acordos entre o governador Cid Sampaio e o governo dos Estados Unidos, em editorial intitulado "Patriotismo e sectarismo". A matéria usa de ironia para descreditar os críticos da ajuda norteamericana, associando essa opinião a uma "esquerda-comunista". É interessante notar, no editorial reproduzido abaixo, que a cooperação norte-americana é tratada como "amiga" e os críticos da ajuda como "sectaristas ideológicos", cuja opinião não passaria de "histericismo". Novamente, a retórica da Guerra Fria aparece nas linhas do jornal. O principal crítico dos acordos era Miguel Arraes, e, portanto, o jornal tentava associar a imagem do candidato ao comunismo, trazendo assim a disputa bipolar da Guerra Fria para o pleito estadual. A publicação atribui as críticas aos acordos à propaganda "esquerdo-comunizante". Essa retórica viria a se intensificar com a proximidade das eleições para o governo do estado de Pernambuco. Cada vez mais, o candidato Miguel Arraes seria identificado como um comunista e João Cleofas como o candidato da democracia.

Os acordos firmados pelo Embaixador Lincoln Gordon com o governo pernambucano de certo irão servir para as conhecidas distorções dos falsos patriotas que, enchendo a boca dos velhos slogans de uma tática sectarista, se comprazem em amesquinhar os objetivos da Aliança para o Progresso. Muito conhecida a estratégia destes fabulosos salvadores da pátria e

\footnotetext{
47 Memorandum, Fowler Hamilton to President Kennedy, Feb 9, 1962. Memorandum from the Administrator of the Agency for International Development (Hamilton) to President Kennedy. Washington, FRUS, Volume XXI, American Republics, Document 220. Disponível em: https://history.state.gov/historicaldocuments/frus1961-63v17/d249 Acesso em: 04/12/2017.
} 
defensores dos interesses do povo: se os Estados Unidos demoram ou dificultam uma ajuda, um plano de assistência, uma política voltada aos interesses da região, é porque interessa ao capitalismo do Tio Sam manter o Brasil nessa situação de atraso e de miséria, campo fértil a proliferação de "trusts", a exploração do capital estrangeiros, ao dissoramento das energias vitais do país. Se, porém, carreia para o Brasil recursos monetários e técnicos, então é o caso de temer estes "presentes de grego", pois na verdade o que o ianque desalmado deseja é enraizar, no meio pobre, os tentáculos de polvo de sua dominação agressiva e sem entranhas.

Mas acima dessas explosões retumbantes do sectarismo ideológico impenitente, pairam os fatos concretos e objetivos: na hora em que o Brasil se dispuser a dar à ajuda americana uma destinação severa, eficiente e útil, não nos faltará a cooperação amiga dos Estados Unidos, seja nas soluções de governo a governo, seja de entidades privadas, como o Binter e o Bid, cuja boa-vontade se acha positivada em dezenas e dezenas de empréstimos para fins reprodutivos. Cerca de 800 milhões é quanto Pernambuco vai receber por força dos acordos firmados entre o sr. Cid Sampaio e o Embaixador Gordon. E apenas é de lamentar a estreiteza do partidarismo odiento, mesquinho e negativista haja emperrado o empréstimo que o governo estadual tentou contrair para levar a cabo o plano rodoviário do DER.

[...] A propaganda esquerda-comunizante irá, estamos certos, amesquinhar, distorcer, deturpar o sentido desta ajuda, mas a opinião tem olhos para ver e a sensibilidade para medir onde é que estão os verdadeiros defensores da Nação. Contra palavras e histericismos ocos, a Aliança exibe fatos. E isto Basta (DIÁRIO DE PERNAMBUCO. Patriotismo e Sectarismo. 12/06/1962, p. 04).

Dois exemplos dessa retórica da Guerra Fria apresentadas pelo jornal apareceram em suas páginas às vésperas da eleição. O primeiro deles, do dia 2 de outubro de 1962, foi a publicação da fotografia de um outdoor da campanha de Cleofas, instalado na cidade do Recife, que colocava a seguinte questão: "Já pensou se aqui houvesse um muro de Berlim?" Na legenda da imagem o jornal acusava os comunistas "partidários da candidatura subversiva" de terem quebrado placas colocadas pelos "partidários da candidatura democrática". Afirmava, ainda, que não havia nada de ofensivo nas placas e que elas apenas "lembravam que um muro igual ao de Berlim poderia cortar o país caso eleito o homem de vermelho". Por fim, 
conclamava os democratas pernambucanos a reagirem no pleito do dia 07 de outubro (DIÁRIO DE PERNAMBUCO, 02/10/1962, p. 01)

Imagem 3 - Capa do Diário de Pernambuco de 02 de outubro de 1962.

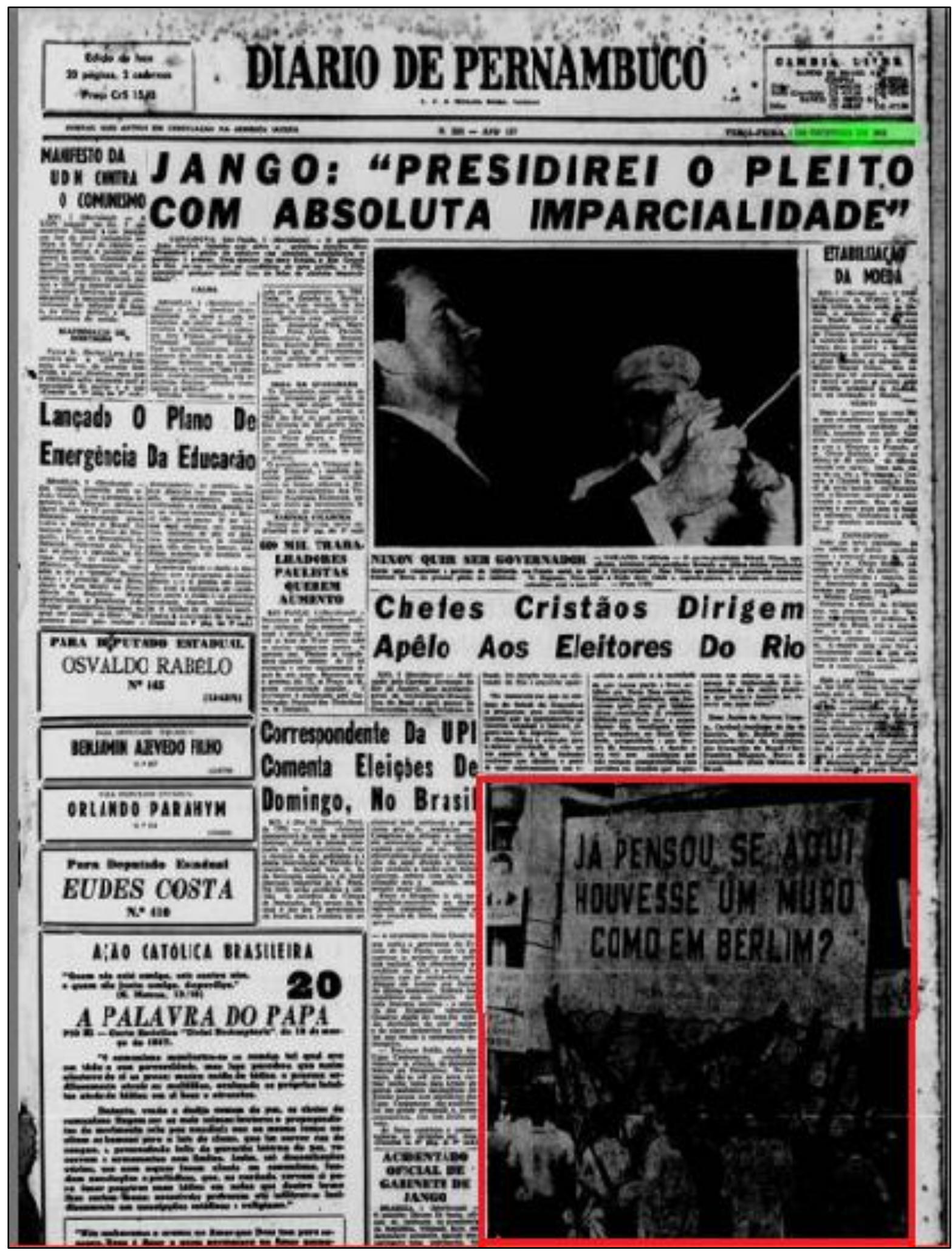

Fonte: Diário de Pernambuco, 02 de outubro de 1962, p. 01. Disponível na Hemeroteca Digital da

Biblioteca Nacional. 
O segundo exemplo é ainda mais emblemático e expressivo. Trata-se de uma charge publicada, no dia 6 de outubro de 1962, onde a retórica da Guerra Fria e a associação de Arraes com os principais elementos do comunismo internacional aparecem explicitamente. Na charge, representada a seguir, podemos identificar Miguel Arraes construindo um muro. Fidel Castro segura uma espécie de projeto cujo título é Berlim. Nikita Kruschev, premier soviético, carrega um "carrinho de mão" com os dizeres "acordos comerciais". Antônio Hermínio de Moraes, candidato ao senado e um dos principais financiadores da campanha de Arraes, aparece misturando cimento. Por fim, Luís Carlos Prestes é retratado empilhando alguns tijolos. No fim da página, havia a seguinte mensagem: "o preço da liberdade é a eterna vigilância" (DIÁRIO DE PERNMBUCO, 06/10/1962 p. 10).

Imagem 4 - Charge publicada no Diário de Pernambuco durante a campanha eleitoral de 1962

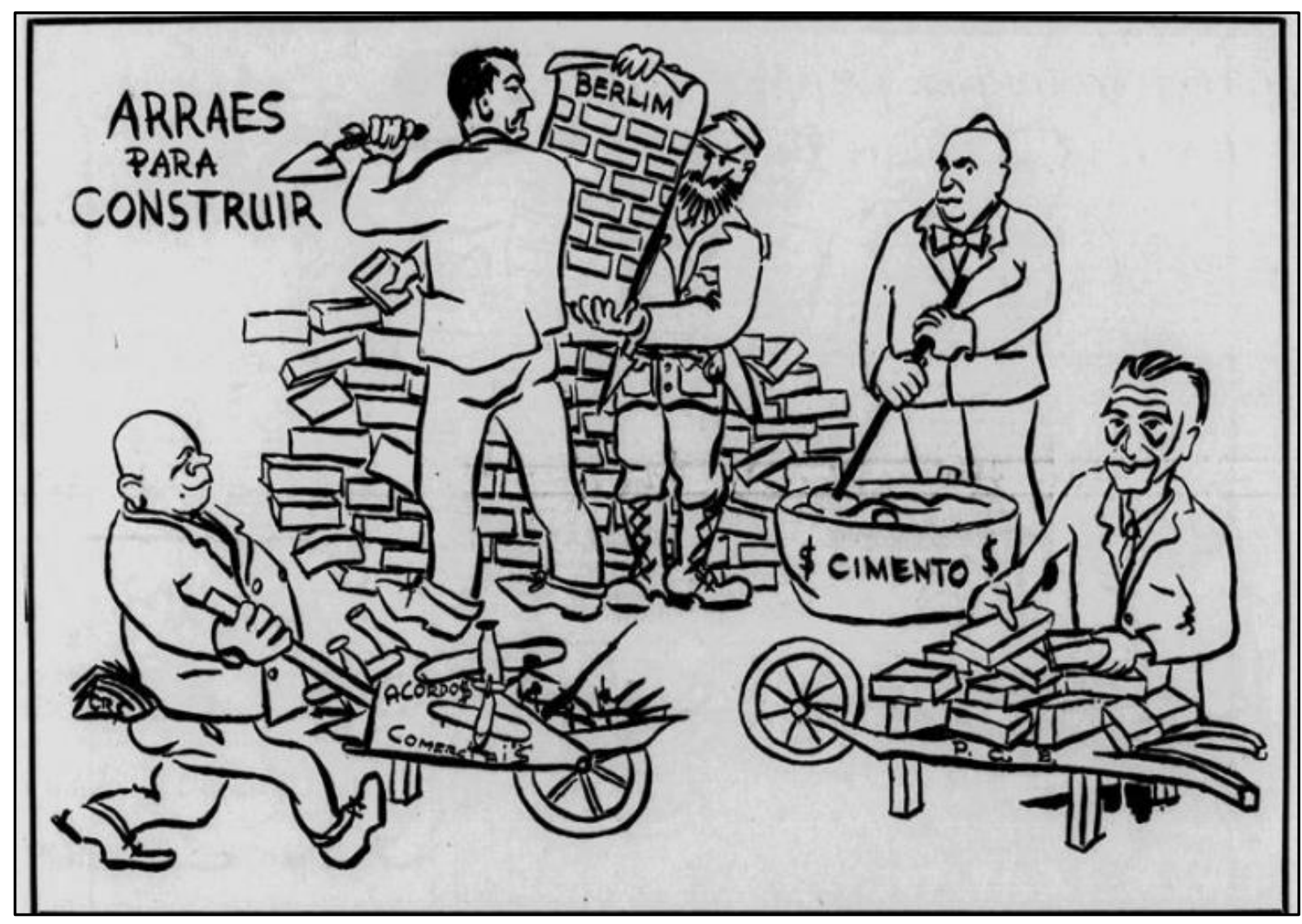

Fonte: Diário de Pernambuco, 06 de outubro de 1962, p. 10. Disponível na Hemeroteca Digital da Biblioteca Nacional. 
Além do Diário de Pernambuco, a campanha política levada a cabo por João Cleofas, nas ruas do Recife, foi tomada pela retórica do anticomunismo, característico da Guerra Fria, como pode ser visto nos panfletos distribuídos pelas cidades do estado. A campanha dedicou-se a associar Miguel Arraes ao comunismo. Um deles dizia:

Ao povo de Pernambuco. Em 1935, Arraes, no Largo da Paz, foi renunciador dos comunistas que ali combatiam as forças legais. As balas ali levadas por Arraes, mataram soldados da polícia e homens do povo, que deixaram viúvas e familiares na miséria. Em 1963, o que fará Arraes? Sectário como é, entregará Pernambuco ao comunismo e à Rússia. Católicos, cristãos, homens de bem, nacionalistas, patriotas, todos nós evitemos esta traição à pátria querida. ${ }^{48}$

Outro dizia: "Povo de Pernambuco, Guardai suas esposas e filhas, Arraes vem aí e com ele o Marxismo [...]" e mais um dizia "Vote em Satanás, mas não vote em Arraes". ${ }^{49}$ A propaganda eleitoral anti-Arraes o representava como uma grande ameaça comunista e apelava para o temor quanto a preservação dos valores familiares. Isso fica evidente quando o folheto instiga a população a "guardarem esposas e filhas" devido a chegada do comunismo. No outro folheto, Arraes é retratado como sendo pior do que Satanás (a personificação de todo mal, aquele que veio ao mundo para roubar, matar e destruir, segundo a tradição cristã), sendo por isso preferível o voto neste do que naquele. Pode-se afirmar, portanto, que transformar a disputa ao governo do estado em um espelho da Guerra Fria foi uma estratégia seguida pela campanha do candidato da UDN, João Cleofas, e acompanhada pelo Diário de Pernambuco em seus editoriais e matérias. Duas capas de 1962, cujas matérias principais afirmavam que havia uma revolução comunista em marcha no Nordeste e que candidatos esquerdistas preocupavam as autoridades na região são exemplos do clima de Guerra Fria representados nas páginas do Diário (DIÁRIO DE PERNAMBUCO, 13 e 18/04/1962, p. 01 e 01).

Essa situação mexia com o imaginário popular no estado e criava uma cultura do medo. O historiador Antônio Montenegro revela que o incêndio de canaviais na

48 Documento sem Título. Fundo Jordão Emerenciano, Dossiê político Governo Miguel Arraes, Manuscritos, pasta 232.

$49 \mathrm{lbid}$. Em nossa pesquisa de campo, no Arquivo Público Estadual de Pernambuco (APEJE), coletamos 10 desses panfletos de propaganda Anti-Arraes. A maior parte deles associava Arraes ao comunismo. 
Zona da Mata pernambucana foi associado à ameaça comunista. ${ }^{50}$ Através da imprensa, do rádio e nos púlpitos das igrejas, era dito que os incendiários teriam sido comunistas. Segundo o autor, "Assim, era produzida toda uma representação de medo, de temor associado aos incêndios dos canaviais" (MONTENEGRO, 2009, 05). É o caso de uma matéria publicada pelo Diário de Pernambuco, na qual uma criança afirmava que um avião havia ateado fogo a um canavial. Fazendeiros locais diziam que era obra das Ligas Camponesas e dos comunistas (MONTENEGRO, 2009, 05). De um modo geral, essa cultura do medo, que associava o comunismo à Miguel Arraes e às Ligas Camponesas, favorecia João Cleofas.

Somava-se a isso o acirramento dos conflitos no campo. Ainda em 1962 foi regulamentada a sindicalização rural e criada a Superintendência de Política e Reforma Agrária (SUPRA). A SUPRA unificou diversos órgãos com a finalidade de colaborar na formulação de política agrária para o país. Seu principal fim era viabilizar a reforma agrária e surgiu no momento em que o Estatuto do Trabalhador Rural (ETR) começava a tramitar Congresso Nacional. Este foi criado em 1963 e garantiria aos trabalhadores rurais direitos trabalhistas. ${ }^{51}$ Essas conquistas encontraram a resistência dos proprietários de terra, organizados em torno da UDN e do PSD. Muitos proprietários agiram por conta própria, de modo violento, para defender seus interesses. Ao mesmo tempo crescia e radicalizava-se a luta pela reforma agrária. Esse acirramento dos conflitos no campo foi sentido no Nordeste como um todo, particularmente em Pernambuco e na Paraíba. $O$ assassinato do líder camponês João Pedro Teixeira a mando de fazendeiros, em abril de 1962, na Paraíba, é exemplo do acirramento da violência no campo (ABREU e LIMA, 2005, 21). Se acirrava também, em Pernambuco, uma disputa entre a igreja católica e setores da esquerda, comunistas e Ligas Camponesas, pela condução e controle das lutas sociais no meio rural de Pernambuco (MONTENEGRO, 2009, 05).

Pode-se afirmar que esses fatores tiveram efeitos na aplicação dos recursos da Aliança para o Progresso pelo governo dos Estados Unidos. Embora a Aliança para o Progresso tivesse entre seus objetivos a reforma agrária, o programa era também

50 O incêndio de canaviais era uma pratica comum na época. Muitas vezes os próprios trabalhadores incendiavam os canaviais para acelerar a colheita, já que a cana queimada deveria ser colhida em 48 horas ou então seria perdida. Os trabalhadores faziam isso para adiantar o recebimento do pagamento pela colheita.

51 Dicionário Histórico-Biográfico Brasileiro, CPDOC, verbete Superintendência da Política Agrária (SUPRA). Disponível em: http://www.fgv.br/CPDOC/BUSCA/dicionarios/verbetetematico/superintendencia-da-politica-agraria-supra Acesso em: 25/04/2019. 
uma ferramenta para deter o comunismo no hemisfério, com perspectivas de longo e curto prazo. Sob o aspecto de curto prazo, impedir a vitória de Miguel Arraes tornouse importante para o governo norte-americano. A campanha política de João Cleofas e as matérias do Diário de Pernambuco levavam a crer que as disputas no campo eram obra de agentes do comunismo e que Miguel Arraes ou era um desses agentes, ou estava próximo destes. O relatório de 18 de junho de 1962, enviado pelo economista Roberto de Jesus Toro, ao Coordenador da Aliança para o Progresso, Teodoro Moscoso, no qual são sugeridas algumas diretrizes à Aliança para o Progresso, em relação a lideranças e governadores brasileiros, demonstra o efeito dessas impressões no direcionamento dos recursos do programa. O relatório deixa clara a intenção de favorecer Cid Sampaio, a quem seria concedido tratamento amigável, e conter Miguel Arraes, a quem seria dado um tratamento "frio". 52

\begin{abstract}
“Deve-se estabelecer uma política de cooperação ativa e rápida para líderes amigáveis construtivos, conceder o tratamento da burocracia para os líderes demagógicos neutros e o tratamento "frio" para nossos inimigos. Na prática, isso significaria que os pedidos financeiros de grupos, como o COPEG (Companhia Progresso do Estado da Guanabara), deveriam ter aprovação quase instantânea, com o menor tempo de análise. A mesma política seria válida para os homens como o Governador Juraci Magalhães da Bahia, o Governador Cid Sampaio de Pernambuco e outros. A maioria desses líderes está impaciente com o que o ex-ministro das Finanças, Clemente Mariani, chamou de "... burocracia excessiva na Embaixada dos EUA". O tratamento "frio" seria reservado para homens como o Governador Leonel Brizola e o Prefeito Miguel Arrais de Recife. ${ }^{53}$
\end{abstract}

Seguindo na análise do conteúdo do Diário de Pernambuco, buscamos entender o destaque dado as relações entre o estado de Pernambuco e a Aliança para o Progresso e de que modo isso se relacionava aos acontecimentos da política local, explicitadas nos parágrafos acima. A tabela a seguir quantifica as matérias que

\footnotetext{
52 Roberto Jesus Toro era porto-riquenho e economista pela Universidade da Pensilvânia. Serviu as forças armadas norte-americana durante a $2^{\mathrm{a}}$ Guerra. Na época, era presidente do Banco de Ponce. Teodoro Moscoso também era porto-riquenho e antes de ser nomeado coordenador da Aliança para o Progresso, serviu o governo Kennedy como embaixador na Venezuela.

53 Memorandum, Roberto de Jesus Toro to Teodoro Moscoso, Jun 18, 1962. Jesus Toro, Roberto de, 1918-2008, "Report on Brazil" (1962). Opening the Archives: Documenting U.S.-Brazil Relations, 1960s80s. Brown Digital Repository. Brown University Library. https://repository.library.brown.edu/studio/item/bdr:671842/ Acesso em: 29/11/17.
} 
retrataram a ajuda econômica aos estados nordestinos no decorrer dos anos de 1961 a 1963.

Quadro 1 - Notícias a respeito da ajuda econômica da Aliança para o Progresso para estados do Nordeste entre os anos de 1960 e 1963. O total de matérias que trataram da Aliança para o Progresso no período foi de 484.

\begin{tabular}{|l|l|l|l|}
\hline \multicolumn{1}{|c|}{ Estado } & \multicolumn{1}{|c|}{1961} & \multicolumn{1}{c|}{1962} & \multicolumn{1}{c|}{1963} \\
\hline Pernambuco & 3 & 27 & 13 \\
\hline Rio Grande do Norte & - & 10 & 10 \\
\hline Ceará & - & 1 & 1 \\
\hline Paraíba & - & 1 & 3 \\
\hline Piauí & - & 1 & 1 \\
\hline Bahia & - & 1 & 2 \\
\hline Sergipe & - & - & 2 \\
\hline Alagoas & - & 1 & 3 \\
\hline Maranhão & - & 2 & - \\
\hline
\end{tabular}

Fonte: Diário de Pernambuco. Disponível na Hemeroteca Digital da Biblioteca Nacional.

Em 1961, Pernambuco foi o único estado a ser citado como possível beneficiário de programas da Aliança. Em 1962, houve um grande salto no número de matérias que trataram de programas da Aliança no estado, maior do que o segundo colocado, o estado do Rio Grande do Norte, governado por Aluísio Alves (UDN), sendo que a maior parte dessas matérias foi publicada no segundo semestre, no contexto da disputa eleitoral ao governo do estado. Essas matérias tratavam das relações entre o governo de Pernambuco e a Aliança para o Progresso, dos convênios firmados e das realizações em andamento, como pode ser percebido pelas seguintes manchetes: "3 núcleos de colonização rebem benefícios da Aliança para o Progresso", "BID aprovou empréstimo para casas populares no estado: telegrama a Cid", "AID financia três milhões de dólares para a fábrica de borracha sintética", "Pernambuco receberá nesse ano 132 milhões para a educação" (DIÁRIO DE PERNAMBUCO, $09 \mathrm{e}$ 11/08/1962, p. 14 e 14; 25/09/1962, p. 18; 04/10/1962, p. 12). Em alguns casos, as matérias associavam a continuidade da Aliança no estado à eleição de João Cleofas, como por exemplo em: "Cleofas e o Desenvolvimento", que relacionava diretamente o candidato a Aliança e "UPI diz que eleição de Cleofas seria vitória da Aliança", na qual os produtores industriais do estado afirmavam que a vitória de Cleofas representaria a continuidade da Aliança (DIÁRIO DE PERNAMBUCO, 12/08/1962, p. 
05; 16/10/1962, p. 01). Havia um clima de otimismo e de realizações promovidas pelas boas relações entre o governo de Cid Sampaio e a Aliança para o Progresso.

Na segunda metade de 1962, o Diário de Pernambuco e consulado dos Estados Unidos no Recife estavam concentrados em conter o crescimento político de Miguel Arraes e a projetar novas lideranças no Nordeste, notadamente Aluísio Alves. Isso foi publicado explicitamente, como na coluna Periscópio, que disse que "se Miguel Arraes for eleito, especula-se com pessimismo sobre a execução dos programas da Aliança para o Progresso no estado", mas também de modo subjetivo como na página reproduzida a seguir (DIÁRIO de PERNAMBUCO, 01/05/1962, p. 20). Ela chama a atenção para o fato de que a propaganda eleitoral de João Cleofas pode ser confundida pelo leitor com a notícia sobre os investimentos prioritários da Aliança para o Progresso na região Nordeste. A campanha ainda tem como mote o lema "unidos para vencer", que pode ser interpretado como a união entre a Aliança e Cleofas. Os tijolos, que passam a ideia de construção, implicitamente ligam a manchete ao nome de João Cleofas (DIÁRIO DE PERNAMBUCO, 15/10/1962, p. 03). 
Imagem 5 - Propaganda de João Cleofas indiretamente associada à Aliança para o Progresso

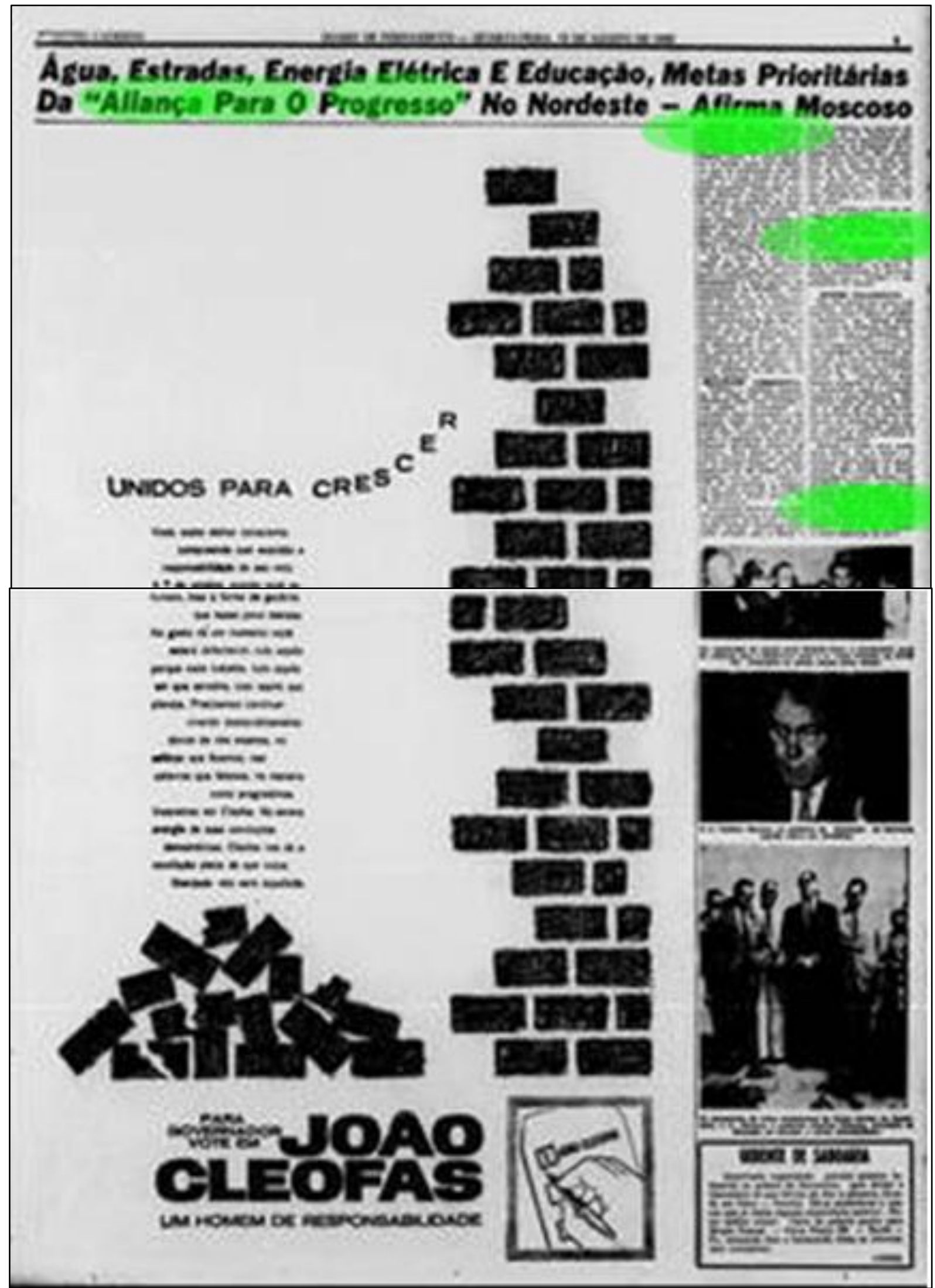

Fonte: Diário de Pernambuco, 15 de agosto de 1962, p. 03. Disponível na Hemeroteca Digital da Biblioteca Nacional. 
Apesar dos esforços contrários do Diário de Pernambuco, do governador Cid Sampaio e João Cleofas, e do próprio governo norte-americano, Miguel Arraes foi eleito governador. Dias depois da vitória de Arraes, em novembro de 1962, a embaixada no Recife manifestou suas impressões a respeito de Arraes como governador e quanto à assistência econômica norte-americana ao estado. $O$ cônsul Delgado Árias dizia que suspeitava que Arraes fosse "comunista, e que se não o fosse, certamente era um extremo-esquerdista". Nota-se que a retórica da Guerra Fria e a associação de Arraes ao comunismo, ou, no mínimo, ao extremismo, foi incorporada pelo consulado norte-americano para retratar a política local. Árias prosseguia recomendando que a assistência econômica, independentemente de ser distribuída de forma direta ou indireta, para um governo liderado por Arraes, iria somente fortalecer a posição do governador e contribuiria para o avanço dos "esquerdistas nacionalistas". Portanto, na visão do Cônsul norte-americano, continuar fornecendo assistência norte-americana a Pernambuco trabalharia contra os interesses dos Estados Unidos. ${ }^{54}$

Se o conteúdo publicado pelo Diário de Pernambuco, a respeito da política local, com contornos que remetem à Guerra Fria, não foi capaz de derrotar Miguel Arraes na disputa pelo governo, certamente interferiram na interpretação feita pelos funcionários norte-americanos do consulado a respeito da política local. Não é nenhum absurdo inferir que os funcionários do consulado lessem o Diário de Pernambuco e que este fosse uma fonte de informação importante a respeito da política local. Nesse sentido, o conteúdo do jornal pode ter contribuído para consolidar a imagem de Miguel Arraes junto ao consulado, como um esquerdista próximo do comunismo.

Empossado, em 31 de janeiro de 1963, o governador Arraes foi hostil à Aliança para o Progresso e nomeou uma comissão de governo para investigar os acordos existentes entre Pernambuco e a USAID/Brasil. O governo norte-americano, por sua vez, demonstrou sua hostilidade ao governador, descrevendo-o como um "esquerdista extremista e ultranacionalista". ${ }^{55} \mathrm{O}$ nacionalismo e a aliança com comunistas eram

54 Airgram A-40, Recife to Department of State, Nov 01, 1962. RG 59, NARA, 1-2.

55 Report, Recife to State Department, Mar 23, 1963. Biographic Report on Miguel Arraes, Governor of Pernambuco (1963). Opening the Archives: Documenting U.S.-Brazil Relations, 1960s-80s. Brown Digital Repository. Brown University

https://repository.library.brown.edu/studio/item/bdr:353895/ Acesso em 29/11/17. 
critérios extremamente relevantes para a diplomacia dos Estados Unidos e, nesse sentido, os Estados Unidos decidiram enfraquecer o governo Arraes através do fortalecimento de outras lideranças no Nordeste, notadamente o governador do Rio Grande do Norte, Aluísio Alves e Lomanto Júnior, governador da Bahia. ${ }^{56}$

No dia $1^{\circ}$ de maio de 1963, a Comissão de Inquérito instaurada por Arraes para investigar os acordos entre o estado de Pernambuco e a USAID terminou seus trabalhos. Ao reunir informações, os membros da Comissão constataram que o governo dos Estados Unidos estava priorizando acordos diretos com estados nos quais os governadores faziam oposição ao presidente João Goulart e beneficiando, com o maior montante de recursos, o provável candidato à presidência Carlos Lacerda, governador do Estado da Guanabara (COELHO, 2012, 411-5). Arraes divulgou o resultado da Comissão na reunião do Conselho deliberativo da SUDENE, diante da presença do embaixador Lincoln Gordon. O relatório da Comissão de Inquérito concluiu que houve interferência da USAID/Brasil na política interna do país. Ao analisar a forma como foram distribuídos os recursos sob sua administração, constatou-se que o estado da Guanabara, recebeu US\$70 milhões, enquanto toda a região Nordeste recebeu US\$13 milhões, cerca de cinco vezes menos que toda a Guanabara. Nos acordos de educação foram constatadas a interferência estrangeira na formulação e controle do programa educacional (COELHO, 2012, p. 406).

O Diário de Pernambuco deu ampla cobertura a este episódio. No conjunto, as matérias publicadas buscaram refutar a denúncia de Arraes e defender a posição norte-americana em relação aos acordos com o estado, dando espaço ao exsecretário de educação, Lourival Vilanova, que nas palavras do jornal "refutou o relatório do grupo de trabalho e sustentou a validade dos convênios celebrados com a USAID" (DIÁRIO DE PERNAMBUCO, 09/1963, p. 3). Sobre o encontro de Arraes e Gordon, durante a reunião do Conselho Deliberativo da SUDENE, o jornal adotou uma narrativa conciliatória. A capa do dia 04 de maio trouxe uma nota em que afirmava que o encontro terminou com um "gesto amistoso", em "shakehand" (DIÁRIO DE PERNAMBUCO, 4/05/1963, p. 3). O Jornal do Comércio, concorrente do Diário de Pernambuco, mas também um jornal ligado aos setores conservadores do estado, descreveu o encontro como "incisivo e travado", em matéria intitulada "Governo do

56 As relações entre os Estados unidos e governo Miguel Arraes serão tratadas no capítulo 03 dessa dissertação, uma vez que são consideradas fundamentais para a compreensão do processo de implementação dos projetos da Aliança para o o Progresso em Pernambuco, tema do capítulo 03. 
estado mostra a verdade sobre a Aliança" (JORNAL DO COMMERCIO, 4/05/1963, p. 10 e 12). A diferença na cobertura dos dois jornais conservadores sobre o mesmo evento demonstra a parcialidade do Diário de Pernambuco em favor do governo norteamericano e da administração Cid Sampaio.

Retomando os dados da tabela 3, nota-se que no ano de 1963 houve uma significativa queda nas matérias que retrataram os programas da Aliança para o Progresso no estado de Pernambuco. Das 13 vezes que apareceram, 9 ocorreram entre janeiro e fevereiro e trataram da inauguração das obras do governo Cid Sampaio. O jornal passou a dar destaque ao governo de Aluísio Alves, no Rio Grande do Norte, como grande exemplo do sucesso que poderia ser obtido pelo trabalho associado entre os governadores e os Estados Unidos.

O destaque ao governador Aluísio Alves e sua relação com a Aliança para o Progresso começaram à medida que as eleições para governador foram se definindo em 1962. Exemplos desse destaque podem ser observados nas seguintes matérias: "Revolução educacional no Rio Grande do Norte"; "Plano de colonização do Rio Grande do Norte"; "Experiência inédita no continente americano", matéria de página inteira com a planta do projeto e seus objetivos, dentre eles transformar os moradores de mocambos em classe de proprietários; "Aliança concederá mais de 2 bilhões de cruzeiros ao RGN: acordo na Sudene"; "Aluísio: Extinção do Analfabetismo"; "Saúde Pública no Rio Grande do Norte" (DIÁRIO DE PERNAMBUCO, 07 e 24/11/1962, p. 08, 09 e 16; 04 e 08/12/1962, p. 03, 03 e 01). Todas essas matérias abordavam os acordos entre o governo do Rio Grande do Norte e a Aliança para o Progresso. Esse destaque se intensificou no ano de 1963.

Em julho de 1963, o Ministro da Justiça, Abelardo Jurema, proibiu que os estados da federação celebrassem acordos diretamente com qualquer entidade estrangeira. Enquanto Miguel Arraes aplaudiu o decreto do Ministro da Justiça, Ildo Meneghetti, governador do Rio Grande do Sul, Carlos Lacerda, governador da Guanabara, Aluísio Alves, governador do Rio Grande do Norte, e Magalhães Pinto, governador de Minas Gerais, ameaçaram renunciar aos seus respectivos cargos caso o decreto não fosse revogado. Notadamente os governadores estavam entre os estados considerados Ilhas de Sanidade. O Diário de Pernambuco saiu em defesa da Aliança e dos governadores beneficiados contra o Ministro da Justiça e o governador Miguel Arraes, através de um editorial publicado no dia 9 de julho, "Apoio à ilegalidade": 
Não causou surpresa o telegrama que o sr. Miguel Arraes enviou ao Presidente da República, João Goulart, congratulando-se pela proibição das negociações financeiras dos Estados com entidades internacionais. As entidades internacionais ou potências estrangeiras contra as quais o chefe do executivo pernambucano se colocou em luta se resumem nos Estados Unidos, cujo programa Aliança para o Progresso se propõe a elevar os níveis de educação, combater a miséria e proporcionar bem-estar aos povos do hemisfério. Esses objetivos, se trazidos ao Nordeste com ajuda norteamericana, não poderiam agradar a ideologia, de todo mundo conhecida, do sr. Miguel Arraes.

Foi ele quem iniciou aqui o duplo combate a Aliança e ao Estado da Guanabara. Disse que através do programa norte-americano, que sua marchinha chama de "Aliança para o Regresso", o Estado vinha negociando diretamente com "potência estrangeira" e isso era ilegal. Na mesma ordem de ideias - para atingir a Guanabara, onde o sr. Carlos Lacerda faz uma das maiores administrações do país - acusou a Aliança de discriminar na distribuição de suas verbas. O que parece contraditório nessa campanha acusar o Estado por negociar diretamente e acusar a Aliança por fornecer maior ajuda a Guanabara - uniu-se no propósito único do governador, que é desacreditar o programa de ajuda influindo nesse sentido, o governo da República. [...].

Já o sr. Miguel Arraes, inspirador da ilegalidade, sozinho exalta com a circular, não se importando com violações da Constituição, nem com a autonomia do Estado. Para ele o que vale é combater os Estados Unidos, que querem ajudar na erradicação da miséria e se a circular pode ser uma barreira a essa ajuda, tudo está bem. O resto é paisagem (DIÁRIO DE PERNAMBUCO. Apoio a ilegalidade. 09/07/1963, p. 04).

O editorial acusa Miguel Arraes de apoiar a ilegalidade, enquanto o governador acusava os acordos firmados com o estado de serem inconstitucionais. Ainda, 0 editorial acusou o governador de ter por interesse combater os Estados Unidos e retomou as insinuações de que Arraes fosse adepto do comunismo ao referir-se a "ideologia de todos conhecida do governador". Por fim, o jornal elogia a administração de Carlos Lacerda na Guanabara e o cita como o principal prejudicado pela proibição. No dia 12 de julho, sob o título de "Ajuda ao Exterior", outro editorial referiu-se 
novamente à ajuda estrangeira direta aos estados. Mais uma vez o jornal saiu em defesa da Aliança.

Este problema da ajuda financeira a Estados e Municípios precisa de uma vez por todas ser olhada em termos realistas e práticos, sem a distorção criminosa de influências ideológicas ou partidárias, que podem acarretar graves consequências para a comunidade a ser beneficiada. Sem nenhuma dúvida, qualquer auxílio estrangeiro que encerrasse a menor ofensa a soberania nacional, a dignidade da pátria, importando qualquer submissão a interesses outros que não a defesa dos interesses do Brasil deveria ser repelida, porque nenhum progresso material valeria o custo, elevadíssimo, da quebra de nossas tradições de autonomia e liberdade. Mas o que a análise serena dos fatos mostra à sociedade é que toda esta celeuma - em tese contra certos programas, mas na verdade tendo como alvo a ALIANÇA PARA O PROGRESSO - não passa de sórdida e ignóbil exploração de grupilhos impatrióticos, interessados em manter este estado das cousas, pois a melhoria nas condições do país seria entrave a seus esquemas de subversão, facilitados pela crise, pela miséria, pelo subdesenvolvimento.

Por outro lado, certas atitudes, camufladas pelo zelo da salvaguarda da dignidade nacional, visam, em derradeira verdade, a dificultar a ação de administrações olhadas como adversárias do governo federal, como é o caso do sr. Carlos Lacerda na Guanabara.

A constituição é muito clara: negócios de Estados e municípios com o estrangeiro estão na dependência exclusiva do controle do Senado, ilegítima dessa sorte, a extralimitação grosseira com que o Ministério da Justiça pretende discipliná-los, invadindo seara que Ihe é defesa e deste modo ferindo de morte o princípio mesmo da Federação. Contra este abuso urge que a nação esteja de atalaia, porque aberta à primeira brecha, outros atentados virão e, mais tarde, todos irão pagar a omissão com que não souberam defender a liberdade (DIÁRIO DE PERNAMBUCO. Ajuda Externa. 12/07/1963, p. 04).

Segundo o editorial, a proibição tinha dois objetivos: sabotar a Aliança para o Progresso e prejudicar o governador Carlos Lacerda, notadamente o principal opositor de Goulart e principal receptor de recursos da Aliança no Brasil.

No decorrer do segundo semestre de 1963, as relações entre o Presidente João Goulart e os Estados atingiram seu clímax. Os Estados Unidos utilizaram as Ilhas de 
Sanidade - apoio a governadores anti-Goulart por meio da Aliança para o Progresso para desestabilizar o Presidente. A grande imprensa trabalhou no mesmo sentido, com exceção do jornal última Hora (CAPELATO, 2014). ${ }^{57}$ O Diário de Pernambuco contribui para essa desestabilização como deixa clara a capa de 19 de novembro de 1963, cuja manchete principal foi "Prepara-se Jango para a República Socialista" e a capa do dia seguinte que trazia uma nota de Júlio de Mesquita Filho, proprietário de O Estado de São Paulo e um dos grandes articuladores civis do Golpe de 1964, que dizia "Jango cairá em breve" (DIÁRIO DE PERNAMBUCO, 19 e 20/11/1963, p. 01 e 01). A ideia de que Jango preparava um golpe, e que, portanto, o golpe de 1964 seria um golpe preventivo, foi a principal tese defendida pelo embaixador Lincoln Gordon para justificar a participação norte-americana nesse processo. ${ }^{58}$ Encontramos aqui um alinhamento entre a retórica do jornal, mais uma vez associada à Guerra Fria e a posição defendida pelo embaixador Gordon.

No plano estadual, o jornal fazia crer que agitadores subversivos estavam por trás das greves que ocorriam no estado de Pernambuco. O editorial, de agosto de 1963, "Comunidade Traída", dizia que "agitadores profissionais" estavam colocando em prática planos ostensivos de subversão (DIÁRIO DE PERNAMBUCO, 11/11/1963, p. 04). Ao mesmo tempo, o jornal acusava Arraes de não tomar medidas para conter as greves no campo, acusando-o de "fazer o perigoso jogo da subversão", enquanto as classes produtoras reclamavam do governador medidas contra os "agitadores" e o "resguardo da segurança pública da população" (DIÁRIO DE PERNAMBUCO, 02 e 03/10/1963, p. 01 e 01). Enquanto isso, o jornal seguia exaltando a capacidade transformadora dos projetos da Aliança para o Nordeste e dando destaque a atuação da Aliança nos demais estados nordestinos.

Foi apenas após a queda do Presidente João Goulart, por meio do golpe civilmilitar de março de 1964, e da deposição do governador Miguel Arraes, que o Diário voltou a referir-se às relações entre a Aliança para o Progresso e o governo do estado de Pernambuco de modo positivo. A partir de abril de 1964, uma série de matérias foi publicada citando a retomada dos programas da Aliança para o Progresso no estado

\footnotetext{
57 Entrevista da historiadora concedida a UNIVESPTV, sob o título "O papel da Imprensa no golpe". Disponível em: https://www.youtube.com/watch?v=2teX16wFfvc Acesso: 12/07/2018.

${ }^{58}$ Sobre as múltiplas versões de Lincoln Gordon sobre o golpe de 1964 ver: James N. Green; Abigail Jones, "Reinventando a história: Lincoln Gordon e as suas múltiplas versões de 1964," Revista. Brasileira de História (online), vol.29, n.57, (2009), p.67-89, acesso em: 12/07/2018, http://www.scielo.br/scielo.php?pid=S0102-01882009000100003\&script=sci abstract\&tlng=pt
} 
e o recebimento de parcelas dos acordos, suspensas desde a administração Cid Sampaio. As manchetes deixam clara a ideia de retomada como por exemplo em "Programas da Aliança para o Progresso serão reiniciados", "CRC continuará casas no Cabo" e "'Aliança para o Progresso colaborará com programa de saúde no estado" (DIÁRIO DE PERNAMBUCO, 11, 14, 16 e 17/04/1964, p. 04, 04, 05 e 05).

A coluna Informativo Econômico, de 5 de abril de 1964, resume a narrativa construída pelo jornal sobre a Aliança para o Progresso, o governo Goulart e Arraes, e a expectativa para o futuro da Aliança após o golpe civil-militar. Nas linhas do jornal, os Estados Unidos pareciam dispostos a continuar o programa de ajuda econômica no Brasil. Os ministérios do ex-presidente Goulart teriam se dedicado a sabotar a Aliança para o Progresso. As acessorias técnicas teriam trabalhado contra os propósitos do programa. No Nordeste, a SUDENE teria sido o principal reduto da luta para impedir que a USAID trabalhasse com os estados em projetos elaborados pelos governadores. Em Pernambuco, o ex-governador preso, que, segundo a matéria, estaria "agora tomando banho de sol em Fernando de Noronha", teria se lançado ao ataque da Aliança para Progresso, ao mesmo tempo que tentaria receber os saldos remanescentes dos acordos feitos com Cid Sampaio. A interferência "moderadora" das forças armadas abriria um novo caminho para o desenvolvimento do Brasil, sem a interferência do comunismo e da corrupção (DIÁRIO DE PERNAMBUCO, 05/04/1963, p. 04).

Pode-se concluir, em virtude das reflexões acerca dos editoriais apresentados, das colunas e do tratamento dado as notícias que há sólidas evidências para afirmar que o Diário de Pernambuco defendeu a Aliança para o Progresso e os acordos diretos entre os governadores e os Estados Unidos. Isso fica evidente no editorial publicado no dia 12 de junho, no qual o jornal saiu em defesa dos acordos entre o governador Cid Sampaio e os Estados Unidos. Naquele momento o consulado norteamericano no Recife e o Diário de Pernambuco estavam empenhados em impedir a vitória de Miguel Arraes nas eleições para o governo do estado. Por essa razão, o jornal buscou associar a Aliança para o Progresso, em Pernambuco, ao candidato apoiado pela situação João Cleofas.

Também se pode verificar que a Aliança foi usada pelo jornal para criticar o Presidente João Goulart e o governador Miguel Arraes, em consonância com as posições do consulado norte-americano no Recife e da embaixada no Rio de Janeiro. O Diário de Pernambuco tratou a tentativa de impedir a interferência norte-americana 
nos assuntos políticos do país, por meio da Aliança, como um ato que visava prejudicar as administrações dos governadores da Guanabara Carlos Lacerda e do Rio Grande do Norte, Aluísio Alves. É o que ocorre, por exemplo, no editorial Ajuda Externas, onde essa afirmação é explicita (DIÁRIO DE PERNAMBUCO. 12/07/1963, p. 04). O Diário de Pernambuco se manteve fiel as posições políticas da UDN e do governo norte-americano durante todo o período analisado por este trabalho.

Além disso, conclui-se que o Diário de Pernambuco contribuiu para a interpretação da política local nos termos bipolares da Guerra Fria, ao adotar uma retórica característica do conflito ideológico. Essa retórica foi usada principalmente durante a disputa para o governo do estado, para prejudicar o candidato Miguel Arraes e beneficiar seu opositor João Cleofas. O jornal continuou a adotar essa retórica durante o governo de Miguel Arraes, em 1963, até sua queda em abril de 1964. O governador foi tratado como comunista em editoriais, notícias e charges.

Por fim, conclui-se que o Diário de Pernambuco retratou a Aliança para o Progresso mais como uma iniciativa norte-americana do que um esforço conjunto da América Latina. Desde seu lançamento, o programa foi, principalmente durante 1961, tratado como a "Aliança do Presidente Kennedy". Além disso, a posição do jornal, em relação aos Estados Unidos, é sempre positiva. Por diversas vezes, o jornal destacou que o fracasso da Aliança seria culpa da América Latina. $O$ único momento em que 0 jornal pareceu tratar da Aliança como um esforço mútuo entre norte e latino americanos foi durante a visita de Goulart aos Estados Unidos em abril de 1962. Nesse contexto de aproximação dos dois países, as origens da Aliança para o Progresso foram relacionadas a OPA. 


\section{Capítulo 03: A implementação dos acordos da Aliança para o Progresso no estado de Pernambuco durante seus anos iniciais.}

Nesse capítulo, busca-se compreender os convênios entre o estado de Pernambuco e o Estados Unidos, bem como sua implementação nos anos iniciais da Aliança para o Progresso no estado. Essa análise foi feita através dos jornais Diário de Pernambuco e Jornal do Commercio - os dois maiores jornais do estado - e através de documentos oficiais do Arquivo Público Estadual Jordão Emerenciano. Destacase, porém, que com exceção do convênio de habitação, os convênios não foram encontrados no arquivo estadual. Contudo, a partir dos relatórios de governo e das publicações dos jornais, buscou-se reconstituir seus principais objetivos e realizações. Apesar dessa lacuna documental, acredita-se que o capítulo cumpre seu papel de oferecer um panorama das realizações da Aliança para o Progresso no estado de Pernambuco, considerando-se sempre o contexto político da sua implementação.

Além do já citado contexto político, considera-se importante para a referida análise dos convênios que se considere as teorias que inspiraram o programa da Aliança para o Progresso, já que estas foram fundamentais para a elaboração dos projetos que foram estabelecidos e financiados pela Aliança na América Latina. Partese, portanto, das teorias de modernização para então analisar os convênios, projetos e implementação da Aliança em Pernambuco. Outro ponto fundamental a ser considerado nesse processo é a relação do governador Miguel Arraes com a ajuda estrangeira e do governo norte-americano com o governador Arraes.

\section{1 - A Aliança para o Progresso como agente de modernização.}

Nos anos 1950, cientistas sociais norte-americanos, com destaque para Walt Rostow, começaram a desenvolver teorias a respeito da modernização tendo como objetivo promover o desenvolvimento dos países do chamado "Terceiro Mundo". A elaboração dessas teorias se deu no contexto da Guerra Fria e da descolonização dos países da África e da Ásia. A União Soviética oferecia um exemplo de sucesso para um rápido processo de industrialização, além de adotar uma postura anticolonial 
que acabava sendo um modelo para as nações recém-independentes. Além disso, nos anos iniciais do conflito, a União Soviética parecia estar vencendo a Guerra-Fria, especialmente sob o prisma da corrida espacial. Nesse contexto, esses cientistas começaram a se dedicar a compreender os processos pelos quais se davam a passagem de sociedades tradicionais a sociedades modernas. Interessados em oferecer uma alternativa de desenvolvimento aos países subdesenvolvidos, que fizesse frente ao modelo soviético, surgiram as primeiras teorias de modernização, com destaque para a proposta por Walt Rostow (ALAGGIO, 2006, 54-5).

Em Stages of Economic Growth, Rostow (1961, 20-3) propõe que o processo de modernização de sociedades tradicionais se dá em cinco etapas. Na primeira delas, a sociedade tradicional possui uma economia baseada em atividades de subsistência. A agricultura é sua principal atividade econômica, os métodos de produção são tradicionais e o uso de mão de obra é intensiva; além disso, a quantidade de capital e o nível de produtividade são limitados. A segunda etapa é considerada de transição. Ocorre a produção de excedentes e incremento do comércio internacional concentrado nos produtos primários. Nessa etapa, tem-se a formação de um Estado nacional centralizado - considerado fundamental para a passagem à terceira etapa, o arranco (take-off). Na terceira fase, ocorre o incremento da industrialização, migração de trabalhadores do setor agrícola para o industrial, acumulação de capital, incremento tecnológico e acesso ao poder político de um grupo capaz de levar a cabo o processo de modernização. A quarta etapa é marcada pela diversificação da economia, incremento tecnológico, desenvolvimento de novas industrias e é tida como a fase de maturidade. A última etapa, na qual se encontrava os Estados Unidos, era a de uma sociedade de consumo de massa, com grande produção de bens de consumo e do setor de serviços. Os Estados Unidos eram, portanto, o modelo de sociedade moderna a ser perseguido pelas sociedades tradicionais, e por isso, poderiam guiar essas sociedades no processo de modernização. A ajuda norte-americana funcionaria como um catalisador para que as sociedades atingissem o terceiro estágio, o arranco ou take-off.

A Teoria de Modernização de Rostow funcionou como uma "poderosa ideologia sobre a natureza da sociedade americana e sua capacidade de acelerar, moldar e dirigir as forças transformadoras" em direção à modernização do terceiro mundo. Sem dúvida, tratava-se de uma resposta à ameaça que se apresentava através Revolução Cubana de 1959 e da União Soviética. No caso da Aliança para o Progresso, a 
ideologia da modernização moldou e legitimou um esforço ambicioso de combinar a promoção do desenvolvimento latino-americano com a contenção do comunismo. Portanto, as teorias de modernização, assim como a Aliança para o Progresso, podem ser entendidas como um produto da Guerra Fria (LATHAM, 1999, 199).

Nesse sentido, os projetos financiados pela Aliança para o Progresso objetivavam não só o desenvolvimento econômico, mas a transformação de sociedades tradicionais em sociedades modernas. Eles visavam melhorar as condições de vida das populações da América Latina e também funcionavam como agentes de modernização. Projetos de habitação, de reforma agrária, entre outros, criavam uma nova categoria de proprietários. $O$ trabalho de Leandro Bemerguini $(2011,320)$ revela esse sentido a respeito dos projetos de habitação da Aliança no Rio de Janeiro e Buenos Aires, mostrando que a "provisão de habitação adequada não era apenas um problema social urgente para o Estado, mas também o lugar onde um novo cidadão e consumidor poderiam ser forjados". No trecho reproduzido abaixo, a ideia de fortalecer a posição capitalista a partir da promoção da propriedade privada fica evidente:

A propriedade e o envolvimento em projetos de autoajuda e desenvolvimento comunitário mostraram uma ajuda externa dos EUA para a integração e socialização dos habitantes pobres da urbanização.[...] A propriedade privada é o capitalismo básico. [...] Se o sistema privado capitalista é propagado e fortalecido no mundo, não há maior apelo aos corações e mentes dos homens do que defender a causa de possuir um lar (BEMERGUINI, 2011, 323)

A partir da influência das teorias de modernização, os projetos da Aliança para - Progresso pretendiam transformar os países da América Latina em nações modernas e formar uma nova classe de proprietários; uma nova classe média. Em Pernambuco, os projetos de habitação e colonização receberam grande destaque na imprensa e tinham entre seus objetivos o de criar uma classe média de proprietários e, além disso, promover a educação em termos de higiene e métodos de produção. É o que fica evidente ao analisarmos as notícias relativas aos projetos. Um dos objetivos dos projetos da Aliança para o Progresso no estado de Pernambuco era promover a modernização do estado sob o viés dessas teorias de modernização. 


\section{2 - Miguel Arraes e Ajuda Externa}

Ao considerarmos os projetos da Aliança para o Progresso no estado de Pernambuco, um fator importante foi a eleição de Miguel Arraes como governador do estado em 1962. A assinatura dos convênios da Aliança com o estado, no contexto das eleições de 1962, foi bastante abordado no capítulo 2, e por outros autores, ficando evidente que por trás da assinatura dos convênios havia motivações políticas que pretendiam evitar a vitória de Arraes. No entanto, esse plano não obteve sucesso e a eleição de Arraes como governador afetou profundamente a implementação desses projetos.

Logo que assumiu, em 31 de janeiro de 1963, o governador eleito anunciou que sua administração não negociaria diretamente com nenhum governo estrangeiro. Todas as negociações de assistência externa deviam ser canalizadas pelo Ministério das Relações Exteriores ou pelo seu representante, no caso a SUDENE (COMISSÃO ESTADUAL DA VERDADE, 2016, 132). Segundo Loureiro $(2017,178)$ Arraes nunca se negou publicamente a receber a ajuda econômica da Aliança para o Progresso, apesar das críticas direcionadas ao programa. Contudo, a visão do governo norteamericano sobre o governador era bastante negativa. Chama a atenção o fato de que de estado modelo e um dos principais receptores de recursos da Aliança, em 1962, junto com Guanabara e Rio Grande do Norte, Pernambuco sofreu uma queda brusca no recebimento de recursos durante a administração Arraes (LOUREIRO, 2017, 166).

A biografia elaborada pelo Consulado Geral norte-americano refletia hostilidade ao governador ao descrevê-lo como um "esquerdista extremista e ultranacionalista, eleito com o apoio do Partido Comunista, com o qual ele sempre manteve uma relação de trabalho muito próxima". Segundo esse relatório, ao tomar posse do cargo, Arraes passou a nomear muitos comunistas e extremistas esquerdistas-nacionalistas para cargos de responsabilidade e influência dentro de sua administração. ${ }^{59}$

O governo norte-americano acreditava que a relação com Arraes deveria ser feita com cautela. Em relatório enviado por Delgado Árias ao Secretário de Estado, Dean Rusk, datado de 7 de fevereiro de 1963, o consulado recomendava que a aproximação de Arraes fosse feita com "cuidado". O relatório informava que Arraes

\footnotetext{
59 Report, Recife to State Department, Mar 23, 1963. Biographic Report on Miguel Arraes, Governor of Pernambuco (1963). Opening the Archives: Documenting U.S.-Brazil Relations, 1960s-80s. Brown Digital Repository. Brown University https://repository.library.brown.edu/studio/item/bdr:353895/ Acesso em 29/11/17. Library.
} 
era totalmente antagonista à presença norte-americana no Brasil e à Aliança para o Progresso. Entre as evidências constavam a associação passada e atual de Arraes com os comunistas. O cônsul geral Delgado Árias, em seu relatório, ainda fez menções às declarações contrárias à Aliança para o Progresso feitas pelo governador em suas conferências de imprensa e em seu discurso inaugural, e criticou a nomeação de comunistas, pró-comunistas e elementos de posição nacionalista de extrema esquerda para cargos do governo estadual. "Os sentimentos de Arraes quanto aos Estados Unidos e a Aliança para o Progresso não são fruto de desentendimento, mas de uma opinião formada ao longo dos anos". ${ }^{60}$ Árias concluiu que "não existe a possibilidade de estabelecer uma relação construtiva com Arraes", ainda que não acreditasse que ele fosse controlado pelos comunistas, ou mesmo que cooperasse com eles. ${ }^{61}$

O relatório da Comissão de Inquérito instaurado para investigar os acordos da Aliança com o governo do estado concluiu que houve interferência da USAID/Brasil na política interna do país. Ele recomendava que o estado de Pernambuco deveria denunciar os acordos por flagrante inconstitucionalidade; que o estado não deveria admitir nenhuma forma de alienação de seus órgãos administrativos (como a criação de entidades paralelas, por exemplo) para a codireção de programas específicos. 0 relatório também criticou a excessiva propaganda em torno da Aliança. De acordo com o relatório, havia muita propaganda vinculando os projetos à Aliança, o que "criava uma mística" de transformação em torno do programa, sem dar o crédito devido a contrapartida do estado. Pernambuco não deveria admitir que os projetos total ou parcialmente financiados por ajuda externa fossem elaborados, dirigidos ou controlados por representantes de qualquer órgão estrangeiro. O estado poderia firmar acordos dentro da estrutura da Aliança para o Progresso, desde que através do órgão federativo competente - a SUDENE. O estado de Pernambuco deveria ainda alertar as autoridades competentes e a opinião pública quanto ao uso dirigido com objetivos políticos, de vultosos recursos por parte da USAID sem qualquer controle do governo Federal, submetendo a política econômica dos governos locais ao Departamento de Estado (COELHO, 2012, 414-15).

60 Telegram № 178, Recife to State Department, Feb 07, 1963. Action Rio de Janeiro 238 (1963). Opening the Archives: Documenting U.S.-Brazil Relations, 1960s-80s. Brown Digital Repository. Brown University Library. https://repository.library.brown.edu/studio/item/bdr:353951/ Acesso em 29/11/2017. $61 \mathrm{lbid}$. 
Ao analisarmos as partes integrantes dos convênios com o estado de Pernambuco, observamos a ausência da SUDENE nos convênios de habitação, educação e colonização. No entanto, há a participação da Comissão de Coordenação da Aliança para o Progresso (COCAP) e, no caso do convênio de educação, do próprio Ministério da Educação e Cultura (COELHO, 2012, 353-68). É fato que o órgão federal responsável pela administração de projetos de desenvolvimento no Nordeste era a SUDENE, porém havia outro órgão federal que participara dos convênios, no caso a COCAP. O próprio Celso Furtado, após a denúncia de Arraes na reunião do Conselho Deliberativo da SUDENE, buscou minimizar o caso ao dizer que os problemas anteriores já haviam sido resolvidos e que não haviam motivos para interromper a ajuda econômica. O Jornal do Commercio publicou as declarações de Celso Furtado em matéria cujo título era "Acordos com Aliança: Celso contra Arraes" (JORNAL DO COMMERCIO, 15/05/1963, p. 1). O Diário de Pernambuco publicou uma matéria na qual afirmava que o relatório do grupo de trabalho quebrou qualquer possibilidade de diálogo entre Arraes e a USAID (DIÁRIO DE PERNAMBUCO, 05/05/1963, p. 16). Há de se considerar que ambas as publicações conservadoras eram bastante críticas a Arraes e que, portanto, era interessante isolar o governador. Porém, as declarações foram dadas pelo próprio Celso Furtado, Superintendente da SUDENE, instituição a qual Arraes estava "defendendo". Isso é sintomático, pois nem o Superintendente da agência "prejudicada" estava disposto a hostilizar a Aliança para o Progresso, enquanto o governador de Pernambuco buscou capitalizar politicamente o episódio, ainda que não pretendesse abrir mão dos recursos da Aliança (DIÁRIO DE PERNAMBUCO, 04/05/1963, p. 23).

Essa afirmação, que reflete o antiamericanismo de Arraes, se fortalece, pois, apesar do resultado da comissão de inquérito sugerir a denúncia dos acordos por inconstitucionalidade, ele decidiu continuar com o projeto de habitação já iniciado e buscou a liberação dos recursos do BID referentes a continuação desse projeto (DIÁRIO DE PERNAMBUCO, 04/05/1963, p. 23). Como diriam os opositores de Arraes na assembleia legislativa, o governador era contra a Aliança, mas não contra os dólares do BID.

Os Estados Unidos, por sua vez, buscaram dificultar a liberação de algumas parcelas referentes aos acordos de educação e colonização. O governo Arraes, em resposta, atrasou a entrega de algumas dessas obras. A relação entre os dois governos foi bastante conturbada no que diz respeito à Aliança para o Progresso. É 
certo que o nacionalismo de Arraes possuía uma forte retórica anti-imperialista e que os Estados Unidos estavam convencidos de que Arraes era um "extremistaesquerdista", termo que aparece nos documentos oficiais norte-americanos.

No início de 1964, a embaixada dos Estados Unidos tornou sua posição em relação a Arraes bastante clara. Em relatório, afirmava que o governador havia dado ampla liberdade de ação a elementos comunistas e extremistas radicais do movimento trabalhista, particularmente nas áreas rurais. O relatório prosseguia dizendo que ele não havia tomado nenhuma ação que indicasse a intenção de "cubanizar" ou socializar Pernambuco, mas suas atitudes e expressões de política, no entanto, indicavam claramente que se ele tivesse a oportunidade de exercer o poder no Brasil sua conduta inevitavelmente levaria a cubanização. ${ }^{62}$

O mesmo relatório recomendava: 1) a evasão, na medida do possível, de qualquer ação que fortalecesse o prestígio de Arraes como líder ou realizador econômico ou social; 2) evitar confronto público direto, que daria a aparência de tentar disciplinar Arraes; 3) quando no decorrer do programa regional do Nordeste, fosse fortalecida a infraestrutura estadual de Pernambuco, a participação da Aliança para o Progresso deveria ser clara e publicamente identificada; e 4) através do uso de acordos contratuais, como parte dos programas regionais da USAID, ou através da transferência de fundos para canais secretos, se necessário, ou por outros meios, como programas nacionais de assistência ou empréstimos à empresa privada, os Estados Unidos deveriam promover elementos moderados em Pernambuco. ${ }^{63}$

Os Estados Unidos pretendiam fortalecer outras lideranças no Nordeste. É notório que as relações entre Arraes e governo norte-americano prejudicaram a execução dos convênios com o estado; no entanto isso é algo esperado, dado os contornos políticos dados à Aliança para o Progresso pelos dois governos - de um lado o anti-imperialismo nacionalista de Arraes e do outro a cruzada anticomunista dos new frontiers. Tendo em consideração esses dois fatores, a influência das teorias de modernização e a relação entre o governo Arraes e os Estados Unidos, movemos nosso foco de análise para a implementação dos convênios da Aliança no estado de Pernambuco.

\footnotetext{
62 Airgram, Rio de Janeiro to State Department, Dec 17, 1963. Assessment of Arraes Regime and U.S. Attitude Toward It. (1964). Opening the Archives: Documenting U.S.-Brazil Relations, 1960s-80s. Brown Digital Repository. Brown University Library. https://repository.library.brown.edu/studio/item/bdr:363767 Acesso em: 29/11/17. 63 Ibid.
} 


\section{3 - Os convênios e sua implementação}

\subsection{1 - Colonização}

Em 1959 foi criada a Companhia de Revenda e Colonização (CRC) do estado de Pernambuco com o objetivo de elaborar um plano de colonização para este estado. O plano piloto de colonização, elaborado pela CRC, previa a implantação de 43 núcleos nas três áreas fisiográficas do estado: Mata, Agreste e Sertão. Os objetivos desses núcleos eram: produzir gêneros de primeira necessidade para os centros urbanos do estado; construir pequenas indústrias de transformação de produtos agrícolas; promover o treinamento de técnicos e artesãos para outros núcleos da CRC; constituir padrões de empresas rurais modelos; e formar uma elite rural média. Percebe-se aqui a marca da Teoria da Modernização ao pretender-se criar uma elite rural média (JORNAL DO COMMERCIO, 23/06/1962 e 13/11/1962, p. 03). ${ }^{64}$

Primeiramente foram estabelecidos três planos-piloto. O governo Cid Sampaio adquiriu, para fins de colonização, 4.735 hectares de terra, nos municípios de Vitória do Santo Antão, Cabo de Santo Agostinho e Barra de Guabiraba. O primeiro núcleo de colonização foi implantado em Vitória de Santo Antão, com a desapropriação dos engenhos Galileia e Terra-Negra-Barra. O segundo núcleo foi estabelecido em terras vendidas pela Companhia Pernambucana de Borracha Sintética (COPERBO), no munícipio de Cabo de Santo Agostinho. Nesse local, foram adquiridas também terras dos engenhos Serra, Retiro, São Pedro, Natapagipe, Mulinote, Malacoaf, Pau Santo e Mato. O núcleo colonial do Cabo contava com a capacidade para alocar 240 famílias de colonos. No município de Barra do Guabiraba, encontrava-se o terceiro núcleo onde existiam 1.129 hectares destinados a abrigar as famílias excedentes do engenho Galileia. O núcleo colonial do Guabiraba pretendia distribuir 100 lotes, sendo 93 distribuídos entre os colonos, os demais seriam divididos entre a CRC e destinados à cidade para loteamento urbano (JORNAL DO COMMERCIO, 23/06/1962 e 13/11/1962, p. 03). Na imagem abaixo é possível identificar as 3 cidades que

64 Dossiê Político Cid Sampaio disponível no Arquivo Público Estadual de Pernambuco, Fundo Jordão Emerenciano, Manuscritos, Caixa 72. 
receberam núcleos do projeto de colonização. Cabo de Santo Agostinho, no litoral; Vitória de Santo Antão, na Zona da Mata e Barra do Guabiraba no Agreste. ${ }^{65}$

Imagem 6 - Cidades contempladas por projetos da Aliança para o Progresso destinados à colonização ou habitação.

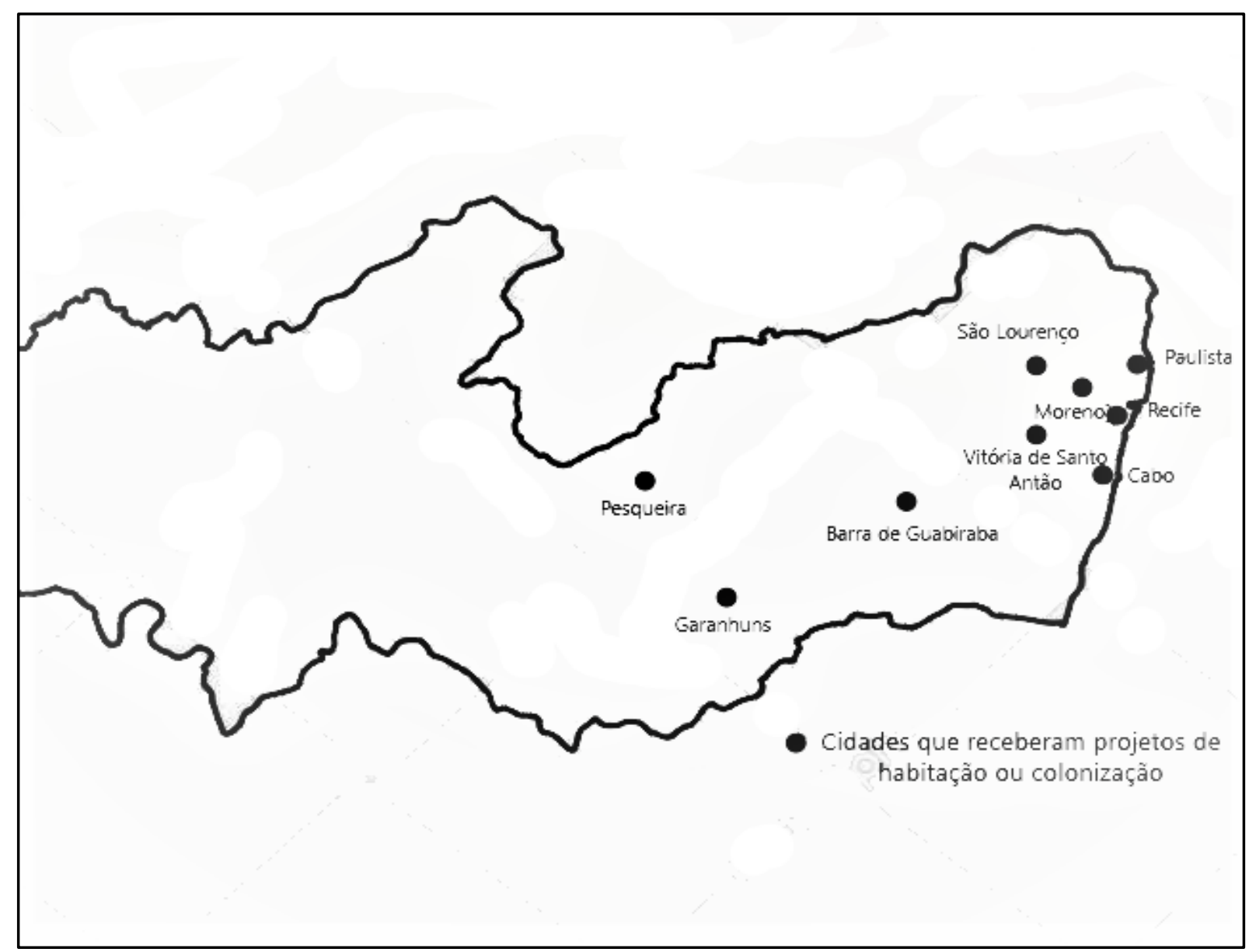

Fonte: autoria nossa.

Num primeiro momento, o governo do estado de Pernambuco solicitou ajuda para o plano de colonização por intermédio do Banco Interamericano de Desenvolvimento (BID). Sem ter obtido uma resposta positiva, solicitou então a ajuda da Aliança para o Progresso e obteve a doação de $\operatorname{Cr} \$ 350$ milhões em 6 de junho de 1962. A contribuição dos Estados Unidos deveria ser empregada na aquisição de materiais de construção para as casas dos colonos, maquinaria e implementos agrícolas, a serem operados na base cooperativa, e na instalação de um centro para as comunidades rurais. Esperava-se, assim, proporcionar às famílias um padrão mais elevado de moradia e alimentação, com a perspectiva de se tornarem proprietários da

\footnotetext{
${ }^{65}$ As demais cidades destacadas no mapa receberam projetos de habitação.
} 
terra e obterem renda em dinheiro da produção destas (JORNAL DO COMMERCIO, 23/06/1962 e 13/11/1962, p. 03).

No dia 03 de junho de 1962, foi assinado o convênio de colonização do governo do estado de Pernambuco entre a USAID e o governo estadual. $O$ acordo foi assinado em conjunto com o convênio de educação. O embaixador Lincoln Gordon e o governador Cid Sampaio foram as autoridades que assinaram o convênio e participaram da cerimônia, representando os governos dos Estados Unidos e do estado de Pernambuco (JORNAL DO COMMERCIO, 23/06/1962 e 13/11/1962, p. 03).

O convênio de colonização assegurava o financiamento de Cr\$350 milhões, o que equivalia a aproximadamente US\$ 1 milhão, em caráter de doação, proveniente do segundo Acordo do Trigo (PL-480). A Companhia de Revenda e Colonização (CRC) do estado era o órgão responsável pela administração e aplicação dos recursos do convênio. O objetivo da doação era a instalação permanente e produtiva de 450 famílias em colônias da CRC. Dê acordo com o embaixador Lincoln Gordon, o projeto deveria servir de modelo e ser seguido em outros lugares (JORNAL DO COMMERCIO, 23/06/1962 e 13/11/1962, p. 03).

Em 22 de junho de 1962, a primeira parcela de Cr\$117,4 milhões foi entregue à CRC. No dia 31 de dezembro de 1962, o chefe do setor de colonização da USAID no Nordeste, Robert R. Perterson, entregou ao presidente da CRC, Douglas Clarck, a segunda parcela do convênio no valor de $\mathrm{CR} \$ 82,7$ milhões. A parcela final de $\mathrm{Cr} \$$ 149,7 milhões só seria paga em abril de 1964, após a queda de Miguel Arraes (JORNAL DO COMMERCIO, 23/06/1962 e 13/11/1962, p. 03; DIÁRIO DE PERNAMBUCO, 01/1/1963, p. 16). O atraso no pagamento da última parcela é reflexo das dificuldades nas relações entre o governador Arraes e o governo norte-americano.

Os primeiros resultados do convênio foram anunciados em 16 de janeiro de 1963. No munícipio do Cabo, o ex-governador Cid Sampaio entregou 189 lotes de 10 hectares e, na mesma tarde, dirigentes da CRC entregaram 70 casas das 189 previstas, construídas em alvenaria com três quartos, sala, terraço, depósito e sanitário. Foram entregues aos camponeses do Cabo 10 moto-bombas, 100 pulverizadores de inseticidas, 100 cultivadores e 50 metros de cano (para cada lote) para irrigação. Na ocasião, o padre Antônio Melo, líder dos camponeses do Cabo, afirmou que Cid Sampaio prometeu e cumpriu o que dissera que faria "uma reforma agrária sem sangue, nem agitação". As casas foram construídas pelos próprios colonos, sob a supervisão de engenheiros construtores da CRC. A autoajuda era uma 
característica importante presente no espírito da Aliança e nas teorias de modernização (DIÁRIO DE PERNAMBUCO, 18/01/1963, p. 03).

Até o início de 1963, a gleba Barra-Terra-Preta contava com 53 lotes de 10 ha ocupados e todos os colonos já possuíam casa. O núcleo estava desenvolvendo uma escola para os filhos dos colonos, uma escola artesanal, e atividades de avicultura e horticultura. Em Vitória de Santo Antão, por outro lado, os colonos não concordaram com o plano de colonização e a situação estava indefinida. O problema era que o governo do estado pretendia instalar o excedente populacional da gleba em outro núcleo de colonização, no Guabiraba. Os colonos da Galileia não aceitavam a supervisão da CRC. Conforme pode-se observar na imagem 6, havia uma grande distância entre Vitória de Santo Antão (Zona da Mata) e Barra de Guabiraba (Agreste). Em Vitória do Santo Antão, estavam previstas a distribuição de 47 lotes de 10 ha. No núcleo colonial do Guabiraba, no início de 1963, 73 lotes encontravam-se devidamente ocupados, nos demais as casas já estavam em fase final de construção (DIÁRIO DE PERNAMBUCO, 18/01/1963). ${ }^{66}$

O núcleo colonial do Cabo só foi concluído em 1964, após a deposição de Miguel Arraes, quando a última parcela do convênio de colonização foi liberada. Em 15 de abril de 1964, o novo presidente da CRC, general Manoel Pais de Lima, recebeu da USAID a parcela final de Cr\$149,7 milhões para o plano de colonização, destinada a finalizar as casas no núcleo de colonização de Cabo de Santo Agostinho (DIÁRIO DE PERNAMBUCO, 16/04/1964, p. 16).

As verbas recebidas pelo convênio de colonização foram utilizadas para a construção de casas de tijolos e telha, galinheiros, salas de aula, sede para a CRC, instalação de escolas e eletrificação. Também foram construídas casas para trabalhadores, vigias, capatazes, professoras, agrônomos, supervisores domésticos e pessoal de manutenção. Foram adquiridos pulverizadores, cultivadores, motobombas, canos de $2^{\text {a }}$ para irrigação, burros, novilhas, aves móveis, caminhões, tratores de pneu, lâminas niveladoras de tração animal, rádios receptorestransmissores, olarias com motor, casas de farinha com motor diesel e material de administração. ${ }^{67}$

Essa longa lista de feitos do convênio de colonização foi apresentada por Miguel Arraes à Assembleia Legislativa Estadual no início de 1963. Sendo o

\footnotetext{
${ }^{66} \mathrm{Ibid}$.
}

${ }^{67}$ Ibid. 
governador um crítico dos convênios com a Aliança, considera-se a lista apresentada bastante positiva. Todavia, o fato de esse convênio ter sido assinado no contexto da disputa eleitoral, abordada no capítulo 2, e, ainda, a última parcela do convênio ter sido entregue apenas após a queda de Arraes reforçam os indícios da motivação política por trás da assinatura desse convênio e, também, das dificuldades da sua execução devido as relações entre Arraes e os Estados Unidos.

\subsection{2 - Habitação}

Como apresentado no capítulo 1 , a região metropolitana do estado de Pernambuco enfrentava um grave problema habitacional relacionado a presença dos mocambos. Ainda na década de 1930, durante a intervenção estadual de Agamenon Magalhães foi criado aquele que seria o embrião do órgão estadual encarregado de gerenciar o problema habitacional no estado. Tratava-se da Liga Social Contra o Mocambo, que deu origem ao Serviço Social Contra o Mocambo.

Pouco tempo depois do lançamento do programa da Aliança para o Progresso, ainda em junho de 1961, o governo de Pernambuco apresentou um projeto de habitação ao Ministro das Relações Exteriores Afonso Arinos com uma proposta de crédito para a construção de 7 mil casas populares no Recife sob o selo da Aliança para o Progresso (DIÁRIO DE PERNAMBUCO, 18/06/1961, p. 26). O Secretário de Viação e Obras, Lael Sampaio, irmão do governador Cid, foi o encarregado de obter entendimentos junto a Comissão Especial do Itamaraty, órgão federal encarregado de apresentar projetos para a Aliança para o Progresso (DIÁRIO DE PERNAMBUCO, 27/07/1961, p. 21).

Esse projeto inicial foi submetido à apreciação do Banco Interamericano de Desenvolvimento (BID) visando a construção das 7.000 unidades habitacionais no Recife e nas cidades do Cabo, Paulista, São Lourenço da Mata, Moreno Caruaru, Garanhuns e Pesqueira, ao custo total de $\operatorname{Cr} \$ 1,4$ bilhões e mais um programa de formação de pessoal e instalação de um Centro de Documentação sobre habitação, ao custo total de $\operatorname{Cr} \$ 75$ milhões. O governo do estado se encarregaria da implantação dos serviços públicos de água, luz e esgoto; e de unidades comunitárias dotadas de posto médico-dentário, escola, centro educativo operário, curso artesanal ou 
profissional. Os imóveis seriam vendidos aos beneficiários do programa em um prazo de 20 anos, à juros de $8 \%$ a.a. 68

O projeto contava com dois tipos de casas, uma de 2 quartos e outra de 3 quartos, está última era considerada mais adequada ao padrão das famílias da região, que tinham um grande número de filhos. Os beneficiários pagariam uma amortização mensal da casa tipo A (2 quartos) $\mathrm{Cr} \$ 1.672,8$ e a casa tipo B (3 quartos) $\mathrm{Cr} \$ 1.923,7$. Os salários mínimos na região variavam entre $\operatorname{Cr} \$ 4.800$ e $\operatorname{Cr} \$ 7.200$ (Recife, Olinda e Moreno). ${ }^{69}$

A distribuição das casas se daria conforme o quadro abaixo e a distribuição foi feita de acordo com a densidade demográfica dos municípios.

Quadro 2: Distribuição das casas do projeto de habitação por munícipio.

\begin{tabular}{|l|l|}
\hline Recife & 4.000 \\
\hline Cabo & 500 \\
\hline São Lourenço & 350 \\
\hline Moreno & 500 \\
\hline Paulista & 500 \\
\hline Caruaru & 400 \\
\hline Garanhuns & 400 \\
\hline Pesqueira & 350 \\
\hline TOTAL & 7.000 \\
\hline
\end{tabular}

Fonte: Projetos sobre Habitação do SSCM e BID, Fundo Jordão Emerenciano, Manuscritos, Caixa 48.

Antes mesmo de submeter o projeto habitacional do estado ao BID, o governo do estado de Pernambuco já havia elaborado e dado início a um projeto-piloto de habitação na área circunvizinha do município de Recife chamada Alto do Jordão. Ali, o governo do estado, através do SSCM, já havia construído 500 casas geminadas com o objetivo de instalar uma comunidade modelo de classe média. Para a execução das obras foi criado o Grupo de Trabalho do Alto do Jordão, GATAJ. ${ }^{70}$

Para a realização do plano de habitação estadual, o governo de Pernambuco solicitou ao BID o empréstimo de US\$ 5 milhões distribuídos da seguinte maneira: a) Programa de habitação urbana para baixa classe média ( 3 mil unidades) a um custo

68 Projetos sobre Habitação do SSCM e BID, Fundo Jordão Emerenciano, Manuscritos, Caixa 48.

Daqui em diante citado no corpo do texto como FJE-48.

69 lbid.

$70 \mathrm{lbid}$. 
total de US\$ 2 milhões; b-) Programa geral de habitação urbana e rural em Pernambuco (7 mil unidades) a um custo total de US\$ 4 milhões. Sendo que o primeiro título do empréstimo (a) seria destinado ao financiamento do projeto-piloto de habitação no Alto do Jordão. Nesse local seriam instalados um centro social, mercado, escola, biblioteca e um posto de saúde. A construção das casas do Alto Jordão estava proposta para ser feita dentro do prazo de 9 meses. ${ }^{71}$

Em suma, o plano habitacional do estado de Pernambuco, apresentado inicialmente ao BID, compreendia um total de 10.000 casas, dividas em 3.000 no plano-piloto do Alto Jordão, das quais 500 já estavam construídas e 7.000 casas, distribuídas conforme o quadro 3. Este plano foi apresentado ainda em 1961 e as discussões prosseguiram até meados de 1962.

Finalmente, em 10 de agosto de 1962, o governador Cid Sampaio recebeu um telegrama do BID, informando que a Diretoria Executiva havia aprovado um empréstimo de US\$3,86 milhões para o programa de habitação popular do governo. O empréstimo destinava-se ao financiamento de 8.500 casas populares no estado e de um programa de assistência técnica de US\$100.000. O programa aprovado pelo BID contemplava 3 projetos: a-) Alto do Jordão - construção de 2.000 unidades, além das 500 já executadas. b-) Interior do estado: 2.500 casas. c-) Limpeza de mocambos para habitações higiênicas mediante sistema de construção por ajuda mútua dirigida (4.000 casas). A escolha das cidades obedeceu ao critério de densidade demográfica e ao pressuposto de que se devia criar em torno do Recife um cinturão de cidadesbarreira contra o intenso fluxo migratório promovido durante os períodos de seca. Os recursos financeiros do empréstimo seriam provenientes do Fundo Fiduciário do Progresso Social, administrado pelo BID e teriam como destinatário o Banco do Nordeste do Brasil (DIÁRIO DE PERNAMBUCO, 11/08/1962, p. 14). No entanto, não podemos deixar de observar que as áreas de alta densidade demográfica eram também os maiores colégios eleitorais e pertenciam a uma área na qual a esquerda possuía tradição de vitória, o que pode sugerir uma tentativa de modificar a opinião política dessas localidades.

A participação da Aliança para o Progresso no programa de habitação popular do estado se deu poucos dias depois da aprovação do empréstimo pelo BID, no dia 11 de agosto de 1962, quando o embaixador Teodoro Moscoso, coordenador da

71 Ibid. 
Aliança para o Progresso, em visita ao projeto-piloto do Alto Jordão, anunciou que a USAID financiaria a construção de mais 700 casas no Alto Jordão (DIÁRIO DE PERNAMBUCO, 14/08/1962, p. 20).

O convênio de habitação popular entre a USAID, a COCAP e o governo do estado foi assinado em 13 de outubro, destinando cerca de $\operatorname{Cr} \$ 200$ milhões a construção das 700 casas no Alto Jordão. Os fundos seriam provenientes do II Acordo do Trigo, em caráter de doação. No dia 23 do referido mês, o governador Cid Sampaio recebeu a primeira parcela de $\mathrm{Cr} \$ 140$ milhões das mãos do o diretor regional da USAID, John Dieffendefer (DIÁRIO DE PERNAMBUCO, 30/08/1962, p. 05).

Apesar do convênio de habitação com a USAID ter sido assinado dias após a eleição, e a primeira parcela ter sido recebida após o reconhecimento da derrota nas eleições do dia 7 de outubro pelo governador Cid Sampaio, a doação para a construção das casas no Alto Jordão foi bastante explorada pelo Diário de Pernambuco, aparecendo ao menos três vezes entre agosto e setembro. O Jornal do Commercio anunciou o recebimento dos $\operatorname{Cr} \$ 200$ milhões doados no dia 6 de outubro, um dia antes do pleito para governador. Riordan Roett $(1972,131)$ destaca que o governo dos Estados Unidos tentou de todas as formas criar um caráter de urgência para o acordo com o estado para evitar a possível vitória de Miguel Arraes. De fato, a entrada da USAID, após a aprovação do programa de habitação popular pelo BID, para o financiamento do projeto-piloto Alto Jordão denota uma certa urgência do governo norte-americano em demonstrar resultados da Aliança durante a administração de Cid Sampaio. Isso se justifica apenas no contexto da disputa eleitoral, e na tentativa de beneficiar seu sucessor João Cleofas, uma vez que o BID já estava participando do projeto de habitação do estado, porém o processo de recebimento pelo órgão seria demorado.

Em dezembro de 1962, foram abertas as inscrições para a venda de 1.100 casas do Alto Jordão, dentre elas as 700 construídas com a doação da USAID. As casas estavam distribuídas em 400 de casas de dois quartos, 550 de 3 quartos e mais 150 casas de 3 quartos no lbura. O projeto-piloto Alto do Jordão foi desmembrado e passou a englobar a região do lbura devido a descoberta de areia granítica em uma área do Alto Jordão. As 150 casas do Ibura foram destinadas a Polícia Militar do estado. Esse conjunto habitacional foi batizado de Vila Aliança, em homenagem ao programa norte-americano (DIÁRIO DE PERNAMBUCO, 11/12/1962, p. 05). 
Os requisitos para as inscrições privilegiavam as famílias numerosas, cujas condições econômicas eram precárias, obedecendo aos seguintes critérios:

a-) famílias de mais de 5 filhos menores e cuja renda mensal não ultrapassasse 4 vezes o salário mínimo, abrangendo $35 \%$ das casas a venda. b-) famílias com mais de 3 e até 5 filhos menores, cuja renda não fosse inferior a 2 vezes o salário mínimo, abrangendo $35 \%$ das casas a venda. c-) famílias de 2 a 3 filhos menores, cuja renda não fosse inferior ao salário mínimo, nem superior a 2 vezes este nível, abrangendo $25 \%$ das casas postas à venda. $d$ ) famílias sem filhos, mas responsável por dependentes até o $2^{\circ}$ grau de parentesco, cuja renda não fosse inferior ao salário mínimo nem ultrapassasse 2 vezes esse valor, abrangendo $5 \%$ das casas à venda (DIÁRIO DE PERNAMBUCO, 11/12/1962, p. 05).

No dia 29 de janeiro de 1963, as casas foram entregues pelo governador Cid Sampaio em uma cerimônia que contou com a exibição de filmes sobre os trabalhos da Aliança no Brasil e no Nordeste, cedidos pelo cônsul Gouglas Elleby, diretor local do United States Information Service (USIS). Muitas das casas entregues não estavam prontas e encontravam-se em fase de levantamento de paredes, revestimento ou cobertura. No entanto, Miguel Arraes estava prestes a assumir o governo do estado, o que justifica a pressa de Cid Sampaio em inaugurar a obra. As casas foram vendidas por $\operatorname{Cr} \$ 360.000$, as de 2 quartos, e por $\operatorname{Cr} \$ 450.000$, as de 3 quartos (DIÁRIO DE PERNAMBUCO, 29/01/1963, p. 16).

Em maio de 1963, Miguel Arraes, já empossado governador, decidiu dar prosseguimento ao convênio de habitação do estado com a USAID. O cheque de Cr\$ 60 milhões, referentes a última parcela da doação foi entregue pelo diretor da USAID a Gildo Guerra do SSCM. O saldo seria utilizado para completar o financiamento das casas no Alto Jordão, que apesar de entregues ainda não estavam prontas (DIÁRIO DE PERNAMBUCO, 05/05/1963, p. 23).

Os US\$ 3,8 milhões de empréstimo acordados com o BID, após 18 meses de negociações, em 30 de novembro de 1963, foram aprovados pela Superintendência da Moeda e do Crédito (SUMOC), permitindo a continuidade da execução do plano de habitação do estado (DIÁRIO DE PERNAMBUCO, 30/11/1963, p. 04). Importante destacar que em 1964, o Diário de Pernambuco denunciou que 1000 casas do Alto Jordão estavam prontas há 6 meses e ainda estavam desabitadas. Conclui-se que as 
1100 casas entregues por Cid em janeiro de 1963, e pelas quais Arraes recebeu verba da USAID para terminar, em maio do mesmo ano, estavam desabitadas mais de um ano depois de entregues. Segundo o jornal, o governo Arraes estava atrasando a entrega das casas para criar dificuldades para a Aliança. O que mais chama a atenção é que em janeiro de 1963 essas mesmas casas foram entregues e inauguradas por Cid Sampaio. Embora não possamos saber ao certo qual a condição das casas, fica claro que o jornal usou as casas para favorecer Cid Sampaio e, tempos depois, usou as mesmas casas para tecer críticas a Miguel Arraes (DIÁRIO DE PERNAMBUCO, 14/02/1964, p. 14).

\subsection{3 - Educação}

Destarte, considera-se importante destacar que, entre 1958 e 1964, as campanhas de alfabetização ganharam destaque no Brasil e no Nordeste com o objetivo de alistar mais eleitores, uma vez que o direito ao voto era restrito aos cidadãos alfabetizados. Pernambuco, Rio Grande do Norte e Sergipe desenvolveram programas de alfabetização baseados, principalmente, no método desenvolvido por Paulo Freire. Contudo, o interesse norte-americano pela educação em Pernambuco se deu no contexto da disputa eleitoral para o governo do estado em 1962 (KIERKENDALL, 2010, 168).

Ainda em 1961, ocorreu um intenso debate entre o Departamento de Estado e a embaixada norte-americana no Brasil a respeito de um programa de construção de escolas que evidenciasse a presença dos Estados Unidos no Nordeste. A princípio, o estado do Rio Grande do Norte foi considerado a primeira opção. Aluisio Alves iniciava seu mandato como governador e seu perfil era interpretado como o tipo político reformista e modernizador com quem os Estados Unidos poderiam trabalhar dentro do espiríto da Aliança para o Progresso. Porém, o consulado norte-americano no Recife sugeriu que o programa fosse levado a cabo no estado de Pernambuco. De acordo com o consulado, além de Pernambuco ser um estado importante, um programa bem-sucedido receberia publicidade e poderia favorecer ao candidato de Cid Sampaio nas eleições de outubro de 1962 (ROETT, 1972, 74). 
As negociações entre a USOM (predecessora da USAID) e o governo de Pernambuco foram abertas em setembro de 1961. Um entendimento sobre a ajuda dos Estados Unidos à educação foi alcançado somente em maio de 1962, quando então as negociações entre os Estados Unidos e o governo de Pernambuco vieram a público. O secretário de educação e cultura de Pernambuco, Lourival Vilanova, anunciou que "o governo do estado estava próximo de celebrar um acordo de combate e redução do analfabetismo". Havia por parte do consulado norte-americano no Recife, "a esperança de que o acordo atraísse votos suficientes para garantir a eleição, em outubro, do candidato do governo estadual” (ROETT, 1972, 75).

No dia 08 de junho de 1962, foi assinado, pelo embaixador Lincoln Gordon e o governador Cid Sampaio, o Pernambuco Aliance for Progress Elementary and Basic Education. O acordo previa a doação de US\$ 1 milhão, aproximadamente Cr\$350 milhões, para a construção de 1800 salas de aulas, com 250 mil matrículas para adultos e crianças, a ser executado em 3 anos (DIARIO DE PERNAMBUCO, 05/06/1962, p. 03).

O convênio previa a alfabetização de cerca de 150.000 adultos, dando-lhes noções de agricultura, higiene, de vida doméstica e de habilidades profissionais e noções de civismo. O acordo ainda previa a promoção de treinamento para 8.000 professores primários, monitores, supervisores e instrutores de alfabetização de adultos e o treinamento, nos Estados Unidos ou outros países, de 25 candidatos que viriam a trabalhar no programa de treinamento de professores (COELHO, 2012, 357). A expectativa era de que, antes do término do governo de Cid Sampaio, fossem inauguradas cerca de 160 salas de aula e que outras 160 estariam em construção (JORNAL DO COMMERCIO, 27/05/1962, p.03).

O acordo de educação envolvia as seguintes partes: o estado de Pernambuco; a Comissão Especial dos Acordos sobre Produtos Agrícolas (CEAPA), a USAID/Brazil, o Ministério da Educação e Cultura do Governo do Brasil e o Representante do Governo Brasileiro para a Coordenação dos Programas de Assistência Técnica (Ponto IV) (COELHO, 2012, 357).

Para a execução do programa de cooperação, o estado de Pernambuco criou o Serviço Educacional de Pernambuco, subordinado à Secretária de Educação e Cultura do estado de Pernambuco. O Secretário de Educação de Pernambuco era o Diretor do Serviço Educacional. O Diretor da USAID/Brazil designaria um assessor em educação da USAID para representa-la junto ao Serviço Educacional. Cabia ao 
Secretário de Educação e Cultura aprovar a designação do representante (COELHO, 2012, 355-6).

O estado de Pernambuco deveria arcar com a maior parte dos investimentos, por meio da concessão de terrenos, materiais e serviços, pessoal qualificado, salários e ajuda de custos para bolsistas, instalação de escritórios, guarda e conservação de material, serviços de engenharia para a construção de escolas (COELHO, 2012, 359).

Em agosto de 1962, o estado de Pernambuco recebeu a importância de $\mathrm{Cr} \$$ 132,5 milhões, para a primeira etapa do projeto de construção de 144 salas de aula, das mãos de Teodoro Moscoso. Cada sala de aula custava em média $\mathrm{Cr} \$ 600.000$ cruzeiros. Os governos municipais doavam os terrenos para a construção das salas de aula. Segundo o secretário Lourival Vila Nova, "obedeceu-se ao princípio de mobilizar o auto esforço local, para que a comunidade participe na solução de seus problemas" (DIÁRIO DE PERNAMBUCO, 07/11/1962, p. 18).

A distribuição das salas de aula privilegiava as cidades da região metropolitana, o que se justifica pela densidade demográfica, mas que também pode indicar uma predileção pelos maiores colégios eleitorais. Essa preferência fica evidenciada na distribuição das salas de aula, construídas com verbas da Aliança, apresentadas no trecho abaixo (JORNAL DO COMMERCIO, 13/11/1962, p. 03):

[...] foram iniciadas a construção de 6 salas no Cordeiro, 6 salas na Mustardinha, e ampliações nos grupos escolares Clotilde de Oliveira e Silva Jardim, com 3 salas em cada um. No interior do estado, já foram iniciadas as construções de 10 salas no Arcoverde, 10 salas em Limoeiro, 10 salas em Correntes, 5 salas de Carnaíba, 2 salas em São Caetano e 1 em Bom Conselho. Ainda esse mês serão iniciadas as obras de construção de 4 salas no grupo escolar Clóvis Bevilaqua, 4 no Joaquim Nabuco, Leal de Barros e Caio Pereira, 6 salas em Prazeres, 4 no Jordão, 3 em Água Preta, 4 em Brejo da Madre de Deus, 7 em Tabira, 3 em São José do Egito, 3 em Jataúba, 3 em Vertentes, 1 em Santa Cruz do Capibaribe, 1 em Belo Jardim, 4 em Custódia, 4 em Itapetim, 7 em Surubim e 5 em Toritama (JORNAL DO COMMERCIO, 13/11/1962, p. 03).

Em fevereiro de 1963, as três primeiras escolas construídas com verbas da Aliança foram concluídas: a escola Othon Paraíso, no Cordeiro, Eleonor Roosevelt, no Imbiribeira e Jackeline Kennedy, na Mustardinha. Somente em 20 de agosto de 
1963, a quarta escola, construída em Carpina, com capacidade para 100 crianças, ficou pronta.

O Diário de Pernambuco acusava o governo Miguel Arraes de estar dificultando a inauguração das escolas construídas pelo convênio com a Aliança para o Progresso. De acordo com o jornal, a escola Eleonor Roosevelt, com 40 salas de aula, encontrava-se pronta e fechada (DIÁRIO DE PERNAMBUCO, 04/11/1963, p. 14). Arraes justificou que nenhuma escola da Aliança havia sido inaugurada pois o governo norte-americano não havia realizado os pagamentos das verbas da Aliança e anunciou que as escolas seriam terminadas, mas com verbas do governo do estado (DIÁRIO DE PERNAMBUCO, 1/11/1963, p. 03). Um relatório de inspeção de campo da USAID para averiguar o sattus da construção das escolas pernambucanas, de setembro de 1963, mais de um ano após a assinatura do convênio, revelava que muito pouco havia sido feito, como demonstra o trecho abaixo:

7 construções escolares concluída até o ponto de ocupação utilizável; 10 escolas dentro de $75 \%$ da conclusão; 19 escolas dentro de $40 \%$ da conclusão; E 9 escolas não iniciadas ou 25\% concluídas. Dos 59 edifícios concluídos, apenas 3 estavam em uso. Os restantes 56 careciam de professores, móveis e suprimentos. Em muitos casos, as ervas daninhas tinham tomado as escolas (ROETT, 1972, p. 138).

Roett (1972, p.136) afirma que, de fato, em março de 1963, uma "linha dura" na educação pernambucana começou a ser praticada pelo governo dos Estados Unidos para dificultar o recebimento das prestações do convênio de educação por Miguel Arraes. Fica evidente que os problemas nas relações entre Arraes e o governo norte-americano foram fundamentais para o fracasso da implementação do projeto de educação no estado.

\subsection{4 - Saúde}

O programa de saúde da missão da USAID para o Nordeste dava ênfase a construção de postos de saúde. A missão estabeleceu como meta a construção de 579 postos de saúde novos ou reformados em dez estados para atender a cerca de um terço da população do Nordeste. Para tanto, foi assinado um acordo global com a a Fundação Federal do Serviço Especial de Saúde Pública (FFSESP) em 4 de junho 
de 1962. A contribuição da USAID deveria ser realizada através de uma série de subacordos com cada um dos estados envolvidos. O primeiro sub-acordo foi assinado, em 12 de setembro de 1962, com o estado de Minas Gerais (ROETT, 1972, p. 1267).

O estado de Pernambuco foi pioneiro no Nordeste em programas de saúde. Seu plano original para melhoria das condições de saúde dizia respeito a construção ou reforma de 50 unidades de saúde para o beneficiamento de 1 milhão e 200 mil pessoas. A USAID assinou um acordo com o governo do estado para acelerar a execução desse programa e aumentar para 97 unidades de saúde, que beneficiariam mais de 2 milhões de pessoas (DIÁRIO DE PERNAMBUCO, 11/12/1962, p. 16)

O sub-acordo para a Promoção da Saúde Pública no estado de Pernambuco foi assinado em 10 de dezembro de 1962 e fundamentou-se no Acordo Básico para Promoção da Saúde no Nordeste do Brasil, assinado em 4 de junho de 1962. Celebraram o sub-acordo: o estado de Pernambuco, a Fundação Especial de Saúde Pública (FSESP) e a USAID/Brazil. ${ }^{72}$ Os recursos da USAID disponibilizados para o ano de 1963 seriam de Cr\$ 240 milhões (COELHO, 2012, p. 362-3).

Barros (2017, p. 113) destaca que os investimentos na área da saúde, no estado de Pernambuco, começaram antes da assinatura do sub-acordo de dezembro de 1962. Pernambuco recebeu, no dia 13 de julho de 1962, duas unidade de clinomobils avaliados em US\$23.000 cada um. Clinomobils eram unidades móveis de saúde equipadas com consultório médico e sala de exame para serem utilizadas em todo o estado. Elas faziam parte de um projeto experimental da USAID a ser operado no interior, onde não existiam postos de saúde e pessoal treinado disponível (ROETT, 1972, p. 126). Além das unidades móveis de saúde, em 03 de outubro de 1962, a Cruz Vermelha do Recife recebeu a doação de 19 mil centímetros cúbicos de sangue da USAID (BARROS, 2017, p. 113).

Em abril de 1964, poucas das estações de saúde estavam em operação e as unidades móveis de saúde não foram colocadas em campo. Para RIOETT (1972, p. 128-9), a missão da USAID falhou em não levar em conta considerações importantes, como por exemplo a falta de pessoal qualificado para operar as estações de sáude. Ao entrevistar sete dos secretários de saúde estaduais envolvidos no programa, o

72 A FSESP surgiu de um contrato entre os governos do Brasil e dos Estados Unidos no campo da saúde pública, criada em 1942, posteriormente, pela lei federal no 3750 de 11/04/1960, foi transformada em uma instituição vinculada ao Ministério de Saúde (COELHO, 2012, p. 363). 
autor destaca que todos os sete concordaram que "o projeto fracassou e que tiveram pouco impacto visível em seus estados".

O estado de Pernambuco ainda recebeu um empréstimo de 3,4 milhões de dólares da USAID para a COPERBO, às vésperas das eleições estaduais de 1962. Além disso, foi assinado um acordo para o abastecimento de água, com a participação da SUDENE.

Em virtude da análise dos dados apresentados e da influência das teorias da modernização e das relações dos governadores Cid Sampaio e Miguel Arraes com o governo dos Estados Unidos, pode-se concluir que durante a administração Cid Sampaio, Pernambuco foi um dos principais receptores de recursos da Aliança para o Progresso devido ao desejo norte-americano de enfraquecer a candidatura de Miguel Arraes, fortalecendo a administração Sampaio. Arraes não deixou essa atitude barata e isso se refletiu no seu antiamericanismo expresso em seus discursos. É notória a fala de Arraes, fumante inveterado, de que os americanos eram ótimos para serem queimados (o governador fumava marcas norte-americanas).

No quadro abaixo estão reunidos as doações e empréstimos feitos através da Aliança para o Progresso para o estado de Pernambuco. Entre doações e empréstimos, os Estados Unidos investiram US\$ 5,3 milhões em Pernambuco. As doações representam aproximadamente $40 \%$ do total de recursos comprometidos com o estado. Este, em contrapartida, se comprometeu a investir US\$ 5,34 milhões. Estados Unidos e Pernambuco investiriam aproximadamente US\$ 44 milhões cada um, em valores atualizados pelo Indíce de Preços do Consumidor dos Estados Unidos. ${ }^{73}$

${ }^{73}$ Memorandum, William Brubeck to Ralph Dungan, Fev 11, 1963. Brubeck, William H., "AID Program and U.S. Policy in the State of Pernambuco, Brazil" (1963). Opening the Archives: Documenting U.S. Brazil Relations, 1960s-80s. Brown Digital Repository. Brown University Library. https://repository.library.brown.edu/studio/item/bdr:669036/ Acesso em: 29/11/2017. 
Quadro 3 - Doações e empréstimos da Aliança para o Progresso feitos ao estado de Pernambuco entre 06/1962 e 01/1963.

\begin{tabular}{|l|l|l|}
\hline & Doações & Empréstimos \\
\hline Campo de Atividade & Cruzeiros & Dólar \\
\hline Colonização & 350.000 .000 & \\
\hline Educação & 200.000 .000 & \\
\hline COPERBO & & 3.400 .000 \\
\hline Habitação & 200.000 .000 & \\
\hline Saúde & 240.000 .000 & \\
\hline Total & 990.000 .000 & 3.400 .000 \\
\hline
\end{tabular}

Fonte: Memorandum, William Brubeck to Ralph Dungan, Fev 11, 1963. Brubeck, William H., "AID Program and U.S. Policy in the State of Pernambuco, Brazil" (1963). Opening the Archives: Documenting U.S.-Brazil Relations, 1960s-80s. Brown Digital Repository. Brown University Library. https://repository.library.brown.edu/studio/item/bdr:669036/ Acesso em: 29/11/2017.

Apesar da grande soma de dinheiro investido em Pernambuco, e dos projetos da Aliança no estado refletirem aspectos das teorias de modernização, poucos resultados foram obtidos. No sentido de constituir uma classe de proprietários que fortaleceria o capitalismo, a quantidade habitações construídas (700 casas) era irrisória - comparada as milhares de pessoas que viviam nos mocambos. Quanto ao objetivo de combater a influência das Ligas Camponesas, através da educação para os grupos sociais menos favorecidos, a Aliança também não atingiu seu objetivo, já que poucas salas de aula estavam em funcionamento até o golpe de 1964. É certo que as dificuldades nas relações entre o governador Miguel Arraes e o governo norteamericano foram imperativas no fracasso na implementação dos projetos da Aliança no estado, haja visto o pouco resultado apresentado. Porém, o uso político da Aliança foi fundamental para esse fracasso, uma vez que os convênios foram celebrados com o intuito de influenciar as eleições estaduais de 1962. Desse modo, muito anunciado (com a participação do Diário de Pernambuco), mas pouco foi realizado. 


\section{Considerações Finais}

Essa dissertação de mestrado buscou mapear algumas estratégias de grupos sociais conservadores do status quo, notadamente aqueles representados pelo Diário de Pernambuco, para a manutenção do poder político no estado de Pernambuco, por intermédio da Aliança para o Progresso. Desse modo, a ideia de perigo ou ameaça comunista propagada pelas páginas do jornal era parte de uma estratégia que visava prejudicar candidatos considerados de esquerda - na prática eram nacionalistas - e favorecer políticos identificados com os grupos dos latifundiários e usineiros.

Assim, retomando nossa pergunta inicial de pesquisa, "como o Diário de Pernambuco utilizou politicamente a Aliança pata o Progresso no sentido de atender aos interesses dos grupos conservadores locais, representados pelo jornal, concluímos que a Aliança funcionou como uma ferramenta de apoio a esses políticos conservadores. O momento mais evidente desse uso político foi durante as eleições estaduais de 1962. O jornal Diário de Pernambuco buscou associar a Aliança para o Progresso ao governador Cid Sampaio, e, em suas páginas, condicionava a continuidade do programa no estado a vitória de João Cleofas. Além disso, o jornal associou a imagem de Miguel Arraes ao comunismo. Nesse sentido, um jornal nunca é um agente imparcial de transmissão da verdade, mas sim um instrumento de interferência na realidade social que representa a visão de mundo daqueles que se fazem representar pela publicação. No nosso caso, o Diário de Pernambuco representa os interesses das classes conservadoras, dos latifundiários e usineiros do estado de Pernambuco.

A partir desses aspectos, esse trabalho mostrou-se fundamental e necessário. Primeiro porque mostra que as interpretações de documentos produzidos pela imprensa devem ser compreendidas a partir de certos critérios metodológicos. Em segundo lugar, esse trabalho confirma a tese apresentada por muitos outros historiadores de que a Aliança para o Progresso foi um instrumento de intervenção na política interna dos países da América Latina, utilizado pelos Estados Unidos como arma de combate na Guerra-Fria. Porém, essa pesquisa vai um pouco além, e mostra que grupos sociais latino americanos, no nosso caso aqueles grupos sociais representados pelo Diário de Pernambuco, também fizeram uso político do programa e que podem ter influenciado os funcionários do governo norte-americano em favor de seus interesses. Essa afirmação se baseia nas publicações do Diário de 
Pernambuco a respeito da Aliança para o Progresso e no modo como o programa foi utilizado para atacar a PEI do governo federal e para fortalecer políticos de oposição ao Presidente João Goulart, por exemplo.

Sob o aspecto das relações centro e periferia do capitalismo, esse trabalho mostra que a periferia teve um papel importante nas ações dos países do centro sobre a periferia. Isso foi feito, por exemplo, através da adoção de uma retórica da Guerra Fria, que associava candidatos nacionalistas aos comunistas, como no caso de Miguel Arraes. Desse modo, políticos brasileiros conseguiram receber auxílio financeiro dos Estados Unidos para financiar seus projetos de desenvolvimento, sob o pretexto de que estariam combatendo políticos comunistas. Foi o que ocorreu com Cid Sampaio, Aluísio Alves, Carlos Lacerda e outros. Enquanto isso, políticos da oposição foram identificados com a esquerda e foram combatidos pelos Estados Unidos, através da Aliança, como João Goulart, Miguel Arraes e outros considerados muito à esquerda no espectro político. Muito desse combate e associação ao comunismo foi feito por meio da imprensa, no nosso caso pelo Diário de Pernambuco. Isso levanta uma questão fundamental. Até que ponto a interferência dos Estados Unidos na política interna dos países da América Latina, não se deve a influência da imprensa e dos agentes sociais locais? Apesar de não apresentar uma resposta definitiva, os indícios analisados por esse trabalho sugerem que esses agentes locais podem ter tido influência no direcionamento da política externa norte-americana para Pernambuco. Ou seja, apesar de serem relações de forças assimétricas, a periferia teve um papel importante nas ações do centro do capitalismo.

Quanto aos resultados da Aliança para o Progresso no estado de Pernambuco, estes se mostraram pífios. Muito pouco foi realizado e o programa não se mostrou capaz de alterar a condição de vida dos habitantes do estado. Os efeitos da Aliança ficaram restritos ao campo da propaganda política. Primeiro porque buscavam criar uma imagem positiva dos Estados Unidos na região, o que nem sempre funcionou. Em muitos casos, o excesso de logotipos da Aliança estimulou o antiamericanismo. Em segundo lugar, como propaganda política para os governadores estaduais, como foi o caso de Cid Sampaio.

De modo algum esse trabalho encerra as possibilidades de pesquisa sobre 0 tema da interferência da imprensa na política externa e nas relações internacionais do Brasil. Abre-se a possibilidade de analisar como outras publicações agiram no período. Nessa época, houve uma verdadeira batalha ideológica disputada através 
das páginas dos jornais. Embora a maioria dos jornais da grande imprensa fossem conservadores, o Última Hora tinha um caráter nacionalista e foi o único veículo da grande imprensa a defender o Presidente João Goulart e outros políticos nacionalistas como Miguel Arraes, por exemplo. Assim, abre-se a perspectiva de novos estudos sobre o uso político da política externa brasileira pela imprensa, enquanto representante de grupos de interesse. 


\section{Referências Bibliográficas}

\section{Sites visitados}

Foreign Relations of the United States, FRUSO

Biblioteca John Kennedy

Arquivo Público Norte-Americano (National Archives and Records Administration, NARA)

Brown University Library (open archives)

Procondel Sudene

Periódicos (Hemeroteca Digital da Biblioteca Nacional)

Diário de Pernambuco (PE)

Correio da Manhã (RJ)

Última Hora (RJ)

\section{Arquivo Público Estadual Jordão Emerenciano}

Diário Oficial do Estado de Pernambuco (PE)

Jornal do Commercio (PE)

Fundo Jordão Emerenciano 


\section{BIBLIOGRAFIA}

ABREU E LIMA, Maria do Socorro. Construindo o Sindicalismo Rural: lutas, partidos, projetos. 2ª Ed. Recife: Ed. Universitária da UFPE, 2005.

ALLISON, Graham T. Essence of Decision: Explaining the Cuban Missile Crisis. Boston: Little, Brown, 1971.

ALMEIDA, Paulo Roberto. "As relações econômicas internacionais do Brasil dos anos 1950 aos 1980". Revista Brasileira de Política Internacional, 50 (2), 2007, pp. 60-79.

ALVES, Bernard José Pereira. Revisitando as ligas camponesas: lideranças e disputas internas do movimento camponês. REVISTA IDEAS (ONLINE), v. 9, p. 202224, 2018.

ANDRADE de PAULA, Dilma. A Comissão Do Vale Do São Francisco: Planejamento e Política Pública Nas Décadas De 1940-1950. Trabalho apresentado no VI Simpósio Nacional Estado e Poder: Cultura, realizado na Universidade Federal de Sergipe, Campus São Cristovão em outubro de 2010.

ARRIGHI, Jean Michael. OEA: Organização dos Estados Americanos. Barueri, São Paulo: Manole, 2004.

AYERBE, Luis Fernando. Estados Unidos e América Latina: a construção da hegemonia. São Paulo: Editora UNESP, 2002.

BANDEIRA, Luiz Alberto Moniz. De Martí a Fidel: a Revolução Cubana e a América Latina. Rio de Janeiro, Civilização Brasileira, 2009.

BANDEIRA, Luiz Alberto Moniz. O Governo João Goulart: as lutas sociais no Brasil, 1961-1964. 8 Ed. revisada e ampliada. São Paulo: Editora UNESP, 2010.

BANDEIRA, Luiz Alberto Moniz. Presença dos Estados Unidos no Brasil: dois séculos de história. 2ª Ed. Rio de Janeiro: Civilização Brasileira, 1978.

BARROS, Arthur Victor Gonçalves de. A pobreza como estopim da revolução: a Aliança para o Progresso em Pernambuco (1959-1964). Dissertação de Mestrado, Recife: UFPE, 2017.

BENEVIDES, Maria V. A UDN e o udenismo: ambigüidades do liberalismo brasileiro, 1945-1965. Rio de Janeiro: Paz e Terra, 1981.

BENEVIDES, Maria V. O PTB e o Trabalhismo: Partido e Sindicato em São Paulo: 1945-1964. São Paulo: Brasiliense, 1989.

BENMERGUINI, Leandro. "The Alliance for Progress and Housing Policy in Rio de Janeiro and Buenos Aires in the 1960s." Urban History, 36, no. 2, 303-326, 2009.

BERLE. Adolf A. América Latina: diplomacia e realidade. Rio de Janeiro: Distribuidora Record, 1963. 
BETHELL, Leslie. ROXBOROUGH, lan. (org.). América Latina entre a Segunda Guerra Mundial e a Guerra Fria. Rio de Janeiro: Paz e Terra, 1996.

BLACK, Jan Knippers. A Penetração dos Estados Unidos no Brasil. Recife: Fundação Joaquim Nabuco, Editora Massangana, 2009.

BURNS, Bradford Burns. The Unwritten Alliance: Rio Branco and Brazilian-American Relations. London, New York: Columbia University Press, 1966.

CALLADO, Antônio. Os industriais da seca e os galileus de Pernambuco. Rio de Janeiro: Brasiliense, 1960.

CALLADO, Antônio. Tempo de Arraes: a revolução sem violência. Rio de Janeiro: Paz e Terra, 1979.

CANTARINO, Geraldo. 1964 - A Revolução para Inglês ver. Rio de Janeiro: Mauad, 1999.

CAPELATO, Maria Helena. Imprensa e História do Brasil. São Paulo: Alfa e Ômega, 1988.

CASTRO, Josué. Sete palmos de terra e um caixão. Lisboa: Editora Seara Nova, 1975.

CASTRO, Josué. Geografia da Fome. Rio de Janeiro: Antares, 1984.

CAVALCANTI, Paulo. O Caso eu conto como o caso foi: da Coluna Prestes à queda de Arraes: memórias políticas. 4. ed. revista e ampliada. Recife: CEPE, 2008.

COELHO, Germano. MCP: História do Movimento de Cultura Popular. Recife: Ed. do Autor, 2012.

DARNTON, Cristopher. "Asymmetry and Agenda-Setting in US-Latin American Relations: Rethinking the Origins of the Alliance for Progress", Journal of Cold War Studies, Vol. 14, No. 4 (Fall): 55-92.

DEPALMA, Anthony. O homem que inventou Fidel. São Paulo: Companhia das Letras, 2006.

DEZEMONE, Marcus. GRYNSZPAN, Mario. As esquerdas e a descoberta do campo brasileiro: Ligas Camponesas, comunistas e católicos (1950-1964). In FERREIRA, Jorge. REIS FILHO, Daniel Aarão. As Esquerdas no Brasil (Vol. 2): Nacionalismo e reformismo radical (1945-1964). Rio de Janeiro: Civilização Brasileira, 2007.

DREIFUSS, René Armand. 1964: a conquista do estado - ação política, poder e golpe de classes. Petrópolis, Rio de Janeiro: Vozes, 1981. 
FICO, Carlos. O Grande Irmão: da operação Brother Sam aos anos de chumbo. O governo dos Estados Unidos e a ditadura militar brasileira. $2^{\underline{a}}$ Ed. Rio de Janeiro: Civilização Brasileira, 2008.

FURTADO, Celso. Formação econômica do Brasil. 34ª edição. São Paulo: Companhia das Letras, 2007.

FURTADO, Celso. Uma política de desenvolvimento econômico para o Nordeste. Apud. CALLADO, Antônio. Os Industriais da Seca e os "Galileus" de Pernambuco. Aspectos da luta pela reforma agrária no Brasil. Rio de Janeiro: Civilização Brasileira, 1960.

GORDON, Lincoln. A segunda chance do Brasil: a caminho do primeiro mundo. 2坣 Ed. São Paulo: Editora SENAC São Paulo, 2002.

GREEN, James N. and JONES, Abigail. "Reinventando a história: Lincoln Gordon e as suas múltiplas versões de 1964". Rev. Bras. Hist. [online]. 2009, vol.29, n.57, pp.6789.

HIPPOLITO, Lucia. De raposas e reformistas - o PSD e a experiência democrática brasileira (1945 - 64). Rio de Janeiro: Paz e Terra, 1985.

HIRSCHMAN, Albert O. Política Econômica na América Latina. Rio de Janeiro: Editora Fundo de Cultura S/A, 1965.

HIRST, Mônica. Understanding Brazil-United States Relations. Brasília: FUNAG, 2013.

HOBSBAWM, Eric. Era dos Extremos - O Breve Século XX. São Paulo: Companhia das Letras, 2003.

HUGGINS, Martha K. Polícia e Política: Relações Estados Unidos/América Latina. São Paulo: Cortez Editora, 1998.

IANNI, Octavio. O Colapso do Populismo no Brasil. Rio de Janeiro: Civilização Brasileira, 1968.

KIRKENDALL, Andrew. 'Kennedy Men and the Fate of the Alliance for Progress in LBJ Era Brazil and Chile'. Diplomacy and Statecraft, 18, 2007, pp. 745-772.

KIRKENDALL, Andrew. Paulo Freire and the Cold War Politics of Literacy. University of North Carolina Press, 2010.

LANOUE, Kenneth. An Alliance Shaken: Brazil and the United States, 1945-1950. PhD Dissertation, Lousiana State University, 1978.

LATHAM, Michael E. "Ideology, Social Science, and Destiny: Modernization and the Kennedy-Era Alliance for Progress". Diplomatic History, Volume 22, Issue 2, April 1998, p. 199-229. 
LATHAM, Michael E. Modernization as Ideology. American Social Science and "Nation Building" in the Kennedy Era. Chapel Hill, NC: The University of North Carolina Press, 2000.

LEACOCK, Ruth. Requiem for Revolution: The United States and Brazil, 1961-1969. Kent and London: Kent State University Press, 1990.

LE GOFF, Jacques. História e Memória. São Paulo: Ed. Unicamp, 1996.

LOUREIRO, Felipe Pereira. Varrendo a democracia: considerações sobre as relações políticas entre Jânio Quadros e o Congresso Nacional. Revista Brasileira de História (Impresso), v. 29, 2009, p. 187-210.

LOUREIRO, Felipe Pereira. "The Alliance For or Against Progress? US-Brazilian Financial Relations in the Early 1960s." Journal of Latin American Studies 46 (02), 2014, p. 323- 51.

LOUREIRO, Felipe Pereira. Aliança para poucos: ajuda econômica norte-americana para estados brasileiros durante o governo João Goulart (1961-1964). Tese de Livre Docência apresentada à Universidade de São Paulo, USP, Brasil, 2017.

LOUREIRO, Felipe Pereira. Empresários, Trabalhadores e Grupos de Interesse: a Política Econômica nos Governos Jânio Quadros e João Goulart (1961-1964). ed. São Paulo: UNESP/FAPESP, 2017. v. 1. 598p.

LOUREIRO, Felipe Pereira; GOMES JR, Hamilton de Carvolho; BRAGA, Rebeca Guerreiro Antunes. "A pericentric Punta del Este: Cuba's failed attempt to join the Latin American Free Trade Area (LAFTA) and the limits of Brazil's independent foreign policy", REVISTA BRASILEIRA DE POLÍTICA INTERNACIONAL (ONLINE), v. 61, p. $1-17,2018$.

LUCA, Tânia Regina de. História dos, nos e por meio dos periódicos. In: PINSKY, C. B. (org.). Fontes Históricas. São Paulo: Contexto, 2005.

MINT, Sidney. A antropologia da produção de Plantation. In SORJ, B., CARDOSO, FH., and FONT, M., orgs. Economia e movimentos sociais na América Latina [online]. Rio de Janeiro: Centro Edelstein de Pesquisa Social, 2008. pp. 127-136.

MONTENEGRO, Antônio T. "As Ligas Camponesas e os Conflitos no Campo”, Saeculum (UFPB) , v. 18, p. 11-31, 2008.

MONTENEGRO, Antônio T. História Política e Cultura do Medo. Confluenze (Bologna) , v. 01, p. 212-226, 2009.

MONTENEGRO, Antonio Torres. História, Metodologia e Memória. São Paulo: Contexto, 2010.

PAGE, Joseph. A Revolução que nunca houve: o Nordeste do Brasil (1955-1964). Rio de Janeiro: Editora Record, 1972. 
PANDOLFI, Dulce Chaves. Pernambuco de Agamenon Magalhães. Recife: Fundação Joaquim Nabuco - Editora Massangana, 1984.

PARKER, Phyllis. Brazil and the Quiet Intervention, 1964. Austin, TX: University of Texas Press, 1979.

PORFÍRIO, Pablo. Medo, Comunismo e Revolução. Pernambuco (1959-1964). Recife: Editora Universitária da UFPE, 2009.

PORTANTIERO, Juan Carlos. O Marxismo latino-americano. In HOBSBAWM, Eric J. [et al.]. História do Marxismo: O Marxismo hoje (vol. XI). Rio de Janeiro: Paz e Terra, 1989.

RABE, Stephen. The Most Dangerous Area in the World. John F. Kennedy Confronts Communist Revolution in Latin America. Chapel Hill, NC and London: University of North Caroline Press, 1999.

REBOUCAS, Aldo da C. "Água na região Nordeste: desperdício e escassez", Estud. av., São Paulo, v. 11, n. 29, p. 127-154, Abril. 1997. Disponível em: http://www.scielo.br/scielo.php?script=sci arttext\&pid=S0103-

40141997000100007\&lng=en\&nrm=iso

ROETT, Riordan. The politics of foreign aid in the Brazilian Northeast. Nashville, TN: Vanderbilt University Press, 1972.

SANTIAGO, Vandeck. Pernambuco em chamas: a intervenção dos EUA e o golpe de 1964. Recife: Cepe Editoria, 2016.

SARZYNSKI, Sarah R. History, Identity, and the Struggle for Land in Northeastern Brazil, 1955 - 1985. PHD thesis presented to University of Maryland, 2008.

SCHLESINGER. Arthur M. Mil dias: John F. Kennedy na Casa Branca. Vol.1. Civilização Brasileira: Rio de Janeiro, 1966

SIGAUD, Lygia. Greve nos Engenhos. Rio de Janeiro: Paz e Terra, 1980.

SKIDMORE, Thomas. Brasil: de Getúlio a Castelo. São Paulo: Cia das Letras, 2010 (1967).

STOKES, Joseph M. "The International Cooperation Administration", World Affairs, Vol. 119, No. 2 (Summer, 1956), pp. 35-37 Disponível em:

https://www.jstor.org/stable/20669215

STORSS, Keith Larry. Brazil's Independent Foreign Policy, 1961-1964: Background, Tenets, Linkage to Domestic Politics, and Aftermath. Thesis Presented to the Faculty of the Graduate School of Cornell University, 1973.

SZULC, Tad. The Winds of Revolution: Latin America today and tomorrow. Nova York: Praeer, 1964. 
TAFFET, Jeffrey. Foreign Aid as Foreign Policy. The Alliance for Progress in Latin America. London and New York: Routledge, 2007.

TRACHTENBERG, Marc. The Craft of International History: a Guide to Method. Princeton: Princeton University Press, 2006.

VIZENTINI, Paulo Fagundes. Relações Internacionais do Brasil: de Vargas a Lula. São Paulo: Fundação Perseu Abramo, 2002.

WEIS, Michael. Cold Warriors and Coups d'état: Brazilian-American Relations, 19451964. Albuquerque, NM: University of New Mexico Press, 1993.

WEIS, Michael. "The Twilight of Pan-Americanism: The Alliance for Progress, Neocolonialism, and Non-Alignment in Brazil, 1961-1964", The International History Review 23, 2 (2001), p. 322-344. 